\title{
40Ar-39Ar step heating ages of North American tektites and of impact melt rock samples from the Chesapeake Bay impact structure
}

DOI:

10.1016/j.gca.2019.03.004

\section{Document Version}

Accepted author manuscript

Link to publication record in Manchester Research Explorer

Citation for published version (APA):

Assis Fernandes, V., Hopp, J., Schwarz, W. H., Fritz, J. P., Trieloff, M., \& Povenmire, H. (2019). 40Ar-39Ar step heating ages of North American tektites and of impact melt rock samples from the Chesapeake Bay impact structure. Geochimica Et Cosmochimica Acta, 255, 289-308. https://doi.org/10.1016/j.gca.2019.03.004

\section{Published in:}

Geochimica Et Cosmochimica Acta

\section{Citing this paper}

Please note that where the full-text provided on Manchester Research Explorer is the Author Accepted Manuscript or Proof version this may differ from the final Published version. If citing, it is advised that you check and use the publisher's definitive version.

\section{General rights}

Copyright and moral rights for the publications made accessible in the Research Explorer are retained by the authors and/or other copyright owners and it is a condition of accessing publications that users recognise and abide by the legal requirements associated with these rights.

\section{Takedown policy}

If you believe that this document breaches copyright please refer to the University of Manchester's Takedown Procedures [http://man.ac.uk/04Y6Bo] or contact uml.scholarlycommunications@manchester.ac.uk providing relevant details, so we can investigate your claim.

\section{OPEN ACCESS}




\title{
${ }^{40} \mathrm{Ar}-{ }^{39} \mathrm{Ar}$ step heating ages of North American tektites and of impact melt rock samples from the Chesapeake Bay impact structure
}

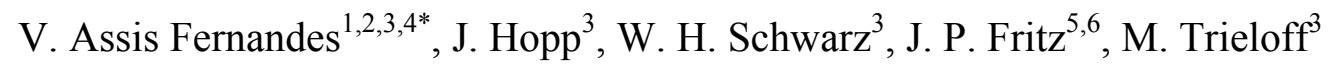 \\ and H. Povenmire ${ }^{6}$
}

${ }^{1}$ Museum für Naturkunde, Leibniz-Institute for Evolution and Biodiversity Research, Invalidenstraße 43, 10115 Berlin, Germany

${ }^{2}$ School of Earth and Environmental Sciences, University of Manchester, Oxford Road, M13 9PL Manchester, United Kingdom ${ }^{3}$ Klaus-Tschira-Labor für Kosmochemie, Institut für Geowissenschaften, Ruprecht-Karls- Universität Heidelberg, Im Neuenheimer Feld 234-236, 69120 Heidelberg, Germany ${ }^{4}$ Instituto Dom Luiz, University of Lisbon, 1749-016 Lisbon, Portugal ${ }^{5}$ Saalbau Weltraum Projekt, Liebigstrasse 6, 64646 Heppenheim, Germany. ${ }^{6}$ Zentrum für Rieskrater und Impaktforschung (ZERIN), Nördlingen, Vordere Gerbergasse 3, 86720 Nördlingen, Germany ${ }^{7}$ Florida Institute of Technology (Retired), Melbourne, FL 32901, U.S.A. *Contact author: Vera Assis Fernandes (veraafernandes@yahoo.com)

\footnotetext{
Abstract

This study presents ${ }^{40} \mathrm{Ar}^{39} \mathrm{Ar}$ step heating ages of four North American tektites (three bediasites and one georgiaite) and two groundmass samples extracted at different depths from clast-rich impact melt rocks (CB-W61 and CB-W84) recovered by the USGS-ICDP Eyreville B drill-core about $9 \mathrm{~km}$ from the centre of the Chesapeake Bay impact structure. Radiometric age determination on both North American tektites and impact melt rocks from within Chesapeake Bay craters offers the first possibility to confirm the origin of these tektites. For this aim, argon data from 13 samples/aliquots of tektite rims, cores and bulk, and 4
} 
samples/aliquots from two impact melt rocks were obtained over 15 to 26 step heating extractions. Age spectra of all tektite samples show plateaux comprising $62-98 \%$ of the ${ }^{39} \mathrm{Ar}$ release over consecutive intermediate and high temperature heating steps. Few low temperature extractions indicate excess ${ }^{40} \mathrm{Ar}$. Inverse isochron ${ }^{40} \mathrm{Ar} /{ }^{36} \mathrm{Ar}$ intercepts of tektite samples are indistinguishable from air (295.5). However, impact melt rock spectra presented complex Ar-release affecting primarily the low temperature heating-steps. Inverse isochrones indicated excess argon from which the ${ }^{40} \mathrm{Ar} /{ }^{36} \mathrm{Ar}$ intercept was used to correct the age calculation. CB-W61 and CB-W61-2 ${ }^{40} \mathrm{Ar} /{ }^{36} \mathrm{Ar}$ intercepts are 354.5 \pm 2.5 and 327.2 \pm 6.3 ,

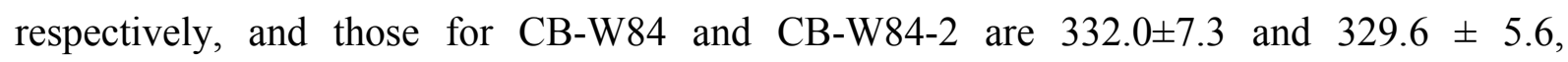
respectively. The inverse isochron weighted mean age (according to currently suggested Kdecay constant revisions by Schwarz et al., 2011 and Renne et al., 2011) for all four tektites is $34.86 \pm 0.25 \mathrm{Ma}(\mathrm{MSWD}=0.96, \mathrm{P}=0.41 ; \mathrm{n}=4)$ and for the two impact melt rocks is $37.16 \pm 3.65$ Ma (MSWD $=0.83, \mathrm{P}=0.36)$. The combined tektite and impact melt rocks isochron mean age of $34.86 \pm 0.23(0.32) \mathrm{Ma}(\mathrm{MSWD}=0.87, \mathrm{P}=0.43)$ is slightly - though not significantly - higher than the plateau mean age of $34.55 \pm 0.27(0.36) \mathrm{Ma}$ (MSWD=0.66, $\mathrm{P}=0.62$ ). Placing the age in the Global Stratotype Section and Point (GSSP) marine section exposed at Massignano, Italy, it falls below the Eocene/Oligocene $(\mathrm{E} / \mathrm{O})$ boundary overlapping with the $10.28 \mathrm{~m} \mathrm{Ir}$ anomaly. These results agree within errors with previously reported ages of $35.20 \pm 0.54 \mathrm{Ma}$ mainly those derived from K-Ar and Ar-Ar total fusion analysis. An age of $34.86 \pm 0.32 \mathrm{Ma}$ sets the Chesapeake Bay impact event close to the youngest of the three Ir anomalies at $\sim 35.0$ Ma in the case the impactor was Ir-rich (e.g, a chondrite, primitive achondrite, stony-iron or iron meteorite). The concordance with the E/O boundary at $~ 33.9$ Ma seems only marginally possible, and only if the Ir contribution from the ejecta were, potentially, due either to its small amount becoming diluted in the geologic record or the impactor being Ir poor, e.g., of differentiated achondritic composition. This study also brings to front the need to re-establish the stratigraphic and palaeo-magnetic correlations across the globe for the Ir-anomalies and 
the magneto-stratigraphy during the mid- to late-Eocene and early-Oligocene, and the need to re-evaluate the markers for the Eocene-Oligocene boundary.

\section{Introduction}

Impact structures on Earth are important geologic markers, and their ejecta layers present isochronous strata, in some cases of global extent (Artemieva and Morgan, 2009). The Chicxulub impact event resulted in the global mass-extinction at the Cretaceous-Paleogene (K-Pg) boundary (Hildebrand et al. 1991; Pope et al. 1991). The associated Ir-anomaly and the shocked-quartz rich ejecta layer represent the strata boundary separating sediments of the Mesozoic and Cenozoic eras, strongly arguing that the impact event was instrumental for the environmental calamities terminating the Mesozoic area (e.g., Alvarez et al., 1980; Schulte et al., 2010). The impact flux onto Earth has not been steady over time; instead, it has been marked by episodes of relatively intense bombardment, e.g., part of the Ordovician period (Schmitz et al., 2001; Korochantseva et al., 2007) or part of the late Eocene epoch (Farley et al., 1998). During the late Eocene, at least 2 large and 2 smaller impact structures formed on Earth: Chesapeake Bay (85 km diameter in size; $35.3 \pm 0.1$ Ma old: Horton and Izett, 2005),

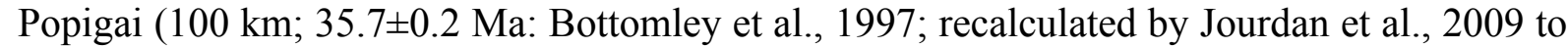
36.42 $\pm 0.81 \mathrm{Ma})$, Mistastin (28 km; $36.4 \pm 4$ Ma: Mak et al., 1976), and Wanapitei $(7.5 \mathrm{~km}$; $37.8 \pm$ 1.6 Ma: Winzer et al., 1976). Other impact structures are Logoisk (15 km diameter) in Belarus, and Beenchime-Salaaty $(8 \mathrm{~km})$ and Longancha $(15 \mathrm{~km})$ in Russia (Bodiselitsch et al., 2004).

During part of the late Eocene and coeval with the formation of two large impact structures (Popigai and Chesapeake Bay) and several small impact ones, a 2 My period with increased flux of extra-terrestrial ${ }^{3} \mathrm{He}$-rich material is reported by Farley et al. (1998). This increase in extra-terrestrial ${ }^{3} \mathrm{He}$-rich material was interpreted to result from either a comet (Farley et al., 1998) or an asteroid shower (Tagle and Claeys, 2004; Fritz et al., 2007; Boschi et al. 2017) 
onto the Earth-Moon system. This intense shower of extra-terrestrial material onto Earth

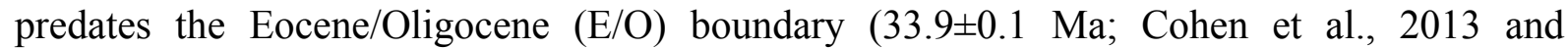
references therein) by $\sim 1.5 \mathrm{My}$.

The late Eocene, including the E/O boundary, is well established in the Global Stratotype Section and Point (GSSP) marine section exposed at Massignano, Italy (Premoli-Silva and Jenkins, 1993). Hilgen and Kuiper (2009) concluded that accurate and precise dating of the E/O boundary is crucial to unravel the cause(s) underlying the major climatic transition associated with it. From the bottom to the top of the GSSP section, three iridium anomalies were reported at $5.61 \mathrm{~m}, 6.17 \mathrm{~m}$ and $10.28 \mathrm{~m}$ by Montanari et al. (1993) and Bodiselitsch et al. (2004). Using astronomical calibration, Jovane et al. (2006) determined the age of the oldest $(5.61 \mathrm{~m})$ and youngest $(10.28 \mathrm{~m})$ Ir-anomalies to $\sim 35.427 \mathrm{Ma}$ and $\sim 34.829 \mathrm{Ma}$, respectively, and the E/O boundary to $33.714 \mathrm{Ma}$. These absolute ages are shifted upwards by $0.186 \mathrm{My}$ if the updated tuning and age of the E/O boundary $(33.9 \pm 0.1 \mathrm{Ma})$ recommended by the International Commission of Stratigraphy are used (Cohen et al., 2013) is used. In an attempt to reduce the difference between radio-isotopic and astrochronology ages, Sahy et al. (2017) suggest a slightly older age for the E/O boundary of $34.09 \pm 0.08 \mathrm{Ma}$, and interpolated ages of $35.49 \pm 0.05$ and $35.0 \pm 0.07 \mathrm{Ma}$ for the Ir-anomalies at 5.61 and $10.28 \mathrm{~m}$, respectively, in the Massignano outcrop.

The two lowermost Ir anomalies (older; $5.61 \mathrm{~m}$ and $6.17 \mathrm{~m}$ ) in the Massignano section are interpreted to be ejecta from the Popigai and, probably, the Chesapeake Bay impact structures, respectively (Bodiselitsch et al., 2004). So far, no impact structure has been assigned to the $\sim 0.6 \mathrm{Ma}$ younger Ir-anomaly at $10.28 \mathrm{~m}$.

In terms of paleo-magnetostratigraphy, there is much debate about correlations for the Iranomalies and the magnetostratigraphy during the mid- to late-Eocene (Montanari et al., 1993). According to these authors, the Ir-anomalies along the Massignano GSSP are located: 1) within Chron 16n2 and a minor one at Chron 16r1, and 2) two smaller Ir-anomalies within 
Chron $13 \mathrm{r}$ in the Contessa section located $80 \mathrm{~km}$ from the Massignano GSSP. Bodiselitsch et al. (2004) considered the negative carbon and oxygen isotopic excursions associated with the Ir-anomalies as evidence for a short-lived warm episode during the continuous cooling occurring between mid-Eocene and Oligocene. This episode is coeval with the Ir-anomaly at $10.28 \mathrm{~m}$ in the Massignano quarry, potentially resulting from large amounts of methane being released during and after an impact event onto the continental shelf, e.g., the Chesapeake Bay impact appears as a plausible candidate.

\section{The Chesapeake Bay impact structure: geology and age}

An impact structure near the present mouth of Chesapeake Bay in eastern Virginia, U.S.A. (Fig. 1) is buried beneath sediments of the Atlantic Coastal Plain. The $\sim 85 \mathrm{~km}$ diameter Chesapeake Bay crater displays the so-called "inverted sombrero" geometry. The crater structure has a central peak inside a $\sim 40 \mathrm{~km}$ diameter deep inner basin, which is surrounded by a shallower brim (Poag et al., 2004; Collins and Wünnemann, 2005). The comparatively shallower outer section was suggested to have formed by resurge-related removal of unconsolidated marine sediments, which constitute the Exmore breccia filling the central crater (Poag et al., 2004). According to numerical models, these structural peculiarities of the Chesapeake Bay crater are consistent with the impact of a $3.2 \mathrm{~km}$ diameter projectile that formed a transient cavity of $28 \mathrm{~km}$ diameter and a corresponding final crater of $\sim 40 \mathrm{~km}$ diameter (Collins and Wünnemann 2005). Notably, the projectile that formed Chesapeake Bay crater was 2.5 times smaller ( $\sim 10$ times less massive) than the $\sim 8 \mathrm{~km}$ diameter projectile required to form the $100 \mathrm{~km}$ diameter Popigai impact structure. Compared to Popigai, the significantly smaller and less energetic Chesapeake Bay event likely did not develop a global ejecta layer (e.g., Glass 2002).

Outcrops of the Chesapeake Bay impact structure are limited and, therefore, sampling relies heavily on drill-cores (Horton et al., 2009a, 2009b). In 2005-2006, a project under the 
auspices of the International Continental Scientific Drilling Program (ICDP) and the U.S. Geological Survey (USGS) acquired the ICDP-USGS Eyreville drill-core from the deepest part of the impact structure, about $9 \mathrm{~km}$ from its centre on the Delmarva Peninsula. Several other cores obtained earlier (e.g., the Langley drill-core, Fig. 1) did not sample impact melt rock. The ICDP-USGS Eyreville drill-core is composed of three segments, A, B and C (Gohn et al., 2009), amounting to a total core-length of $1766 \mathrm{~m}$, providing a representative geologic section from the impact structure (Gohn et al., 2006, 2008, 2009). Section A comprises material obtained between 126.9 and 940.9 m, section B includes depths between 737.6 and $1766.3 \mathrm{~m}$, and section C provides material from 0 to $140.2 \mathrm{~m}$ depth (Horton et al., 2009a). Sections A and B partly overlap between the depths of 618.2 and $1095.7 \mathrm{~m}$, and section C completely overlaps with the top portion of section A (Horton et al., 2009a; Gohn et al., 2009).

\subsection{Stratigraphy of the ICDP-USGS Eyreville drill-core}

The stratigraphy obtained from the ICDP-USGS Eyreville drill-core is comprehensively described in Horton et al. (2009a) and Edwards et al. (2009a, 2009b). The drilling apparently did not reach the crater floor, as surmised from geophysical data (Catchings et al. 2008). A summary of bottom to top (i.e., older to younger) stratigraphy in the 1766-m-long section is reported below:

1) $1766.3 \mathrm{~m}-1551.2: 215 \mathrm{~m}$ of basement-derived metamorphic and igneous rocks (mainly schist, pegmatite, coarse granite) along with local dikes and veins of polymict impact breccia that may exhibit shocked minerals (Horton et al., 2007, 2009b), occasionally showing planar fractures (PFs) and rarely planar deformation features (PDFs) in quartz (Horton et al., 2009b).

2) $1551.2 \mathrm{~m}-1397.2 \mathrm{~m}: 154 \mathrm{~m}$ sequence of polymict impact breccias intermingled with suevites, i.e., impact melt-bearing breccia. This section of the ICDP-USGS Eyreville drillcore was the source of two well-indurated, clast-rich impact melt rocks for which we here 
157

158

159

160

161

162

163

164

165

166

167

168

169

170

171

172

173

174

175

176

177

report the ${ }^{40} \mathrm{Ar}^{39} \mathrm{Ar}$ data. These samples are designated M1 (CB-W84 hereafter; 1451.221450.22 m depth) and M2 (CB-W61 hereafter; 1407.49-1402.02 m depth) by Wittmann et al. (2009). The lower and thinner (1 m tick) impact melt rock CB-W84 is clast-rich and has a hypocrystalline melt matrix (Wittmann et al. 2009). In places, the matrix shows alteration and contains remnants of unaltered glass and microphenocrysts. The upper and thicker ( $5 \mathrm{~m}$ thick) clast-rich impact melt rock CB-W61 has a holocrystalline melt matrix, which is altered in places (e.g., smectite) and contains microphenocrysts. Shocked quartz is ubiquitously distributed in the suevites and lithic impact breccias, with many grains showing two to three sets of decorated PDFs (Horton et al., 2009b). Ballen-quartz, a high-temperature annealing texture; Ferrière et al., 2009) is found as particles in impact melt-rich samples (Horton et al., 2007a, 2009b).

3) $1397.2 \mathrm{~m}-1371.1 \mathrm{~m}$ : - A $26 \mathrm{~m}$ long section consists of quartz-sand with an amphibolite block and lithic boulders and overlies the suevite. The gravelly sand consists of very fine to very coarse quartz sand, minor silt and clay, granules of quartz and feldspar, and sparse quartz pebbles. Self-Trail et al. (2009) also reported early Cretaceous pollen and spores suggesting them to be sourced from the lowest part of the target sediment layer.

4) $1371.1 \mathrm{~m}-1095.7 \mathrm{~m}$ : A 275 -m-thick allochthonous granite slab devoid of any magmatic emplacement features. This slab consists of four intermingled granite types: gneissic biotite granite, fine-grained biotite granite (ubiquitous), medium- to coarse-grained biotite granite, and a $7 \mathrm{~m}$ thick basal zone of altered red biotite granite (e.g., Horton et al., 2009 and references therein). Horton et al. (2009b) reported ion-microprobe (SHRIMP) U-Pb zircon age of $615 \pm 7 \mathrm{Ma}$ for the gneissic biotite granite and an age of $254 \pm 3 \mathrm{Ma}$ for the medium- to coarse-grained biotite granite.

5) $1095.7 \mathrm{~m}-443.9 \mathrm{~m}$ : A $652 \mathrm{~m}$ thick sequence of crater-fill sediments and sediment blocks interpreted as having been deposited by avalanche and ocean-resurge deposits (Gohn et al. 2009a; Reimold et al 2009). 
6) $443.9 \mathrm{~m}-0 \mathrm{~m}$ : A $444 \mathrm{~m}$ thick sequence of post-impact sediments (Gohn et al., 2008;

Edwards et al. 2009a,b).

\subsection{North American tektites}

Bediasites, georgiaites and a single tektite from Martha's Vineyard are considered to be melted ejecta from the Chesapeake Bay structure (Fleischer and Price, 1964; Fleischer et al., 1965; Storzer and Wagner, 1971, 1979; Garlick et al., 1971; Glass et al., 1973). Previous geochemical studies (e.g., Koeberl et al., 1996; Deutsch and Koeberl, 2006) attempted to identify the potential precursor $\operatorname{rock}(\mathrm{s})$ from which these tektites were produced providing a firm link to the Chesapeake impact structure.

\subsection{Summary of reported ages}

Evidence for a coeval origin of the Chesapeake Bay impact structure and the North American tektites is based on biochronology (planktonic, foraminifera, bolboformids and calcareous nanofossils; Poag and Comeau, 1995). Isotopic age determination of this impact structure relies on North American tektites only, specifically fission track dating (Fleischer and Price, 1964; Fleischer et al., 1965; Storzer and Wagner, 1971, 1979; Garlick et al., 1971; Glass et al., 1973), and ${ }^{40} \mathrm{~K} /{ }^{40} \mathrm{Ar}$ and ${ }^{40} \mathrm{Ar}-{ }^{39} \mathrm{Ar}$ total fusion dating (Glass et al., 1986, 1995; Albin et al., 1996; Horton and Izett, 2005). A summary of literature ages is shown in Table A1 in the appendix. The various revisions of monitor ages used for ${ }^{40} \mathrm{Ar}^{39} \mathrm{Ar}$ dating (e.g., Renne et al., 1998; Jourdan and Renne, 2007; Schwarz and Trieloff, 2007), call for a consistent recalculation of the ${ }^{40} \mathrm{Ar}-{ }^{39} \mathrm{Ar}$ age data using the best available age monitor values. Table A1 lists the values for the monitor ages and the ${ }^{40} \mathrm{~K}$ decay constants used originally and in the consistent recalculations reported here. For example, the current age of the Taylor Creek sanidine age monitor is $28.02 \pm 0.28$ Ma (Renne et al., 1998). For this monitor Horton and Izett (2005) used an older age of $\mathrm{t}=28.32 \pm 0.08 \mathrm{Ma}$ (based on MMhb-1 age of $520.4 \pm 1.7$ 
Ma; Samson and Alexander, 1987) and Glass et al. (1995) used a younger age of $27.82 \mathrm{Ma}$

(Dalrymple and Duffield, 1988). In another study, Glass et al. (1986) used the Bern 4B biotite

211

212

with an age of $17.33 \pm 0.10 \mathrm{Ma}$, which has not been updated since, and also the Hb3grhornblnde with an age of $1070 \pm 2 \mathrm{Ma}$, with an updated age of 1073.6 $\pm 4.6 \mathrm{Ma}$ (Schwarz and Trieloff, 2007).

Age data of North American tektites based on the ${ }^{40} \mathrm{Ar}-{ }^{39} \mathrm{Ar}$ total fusion technique (Glass et al., 1986, 1995; Albin and Wampler, 1996; Horton and Izett, 2005) yields a recalculated mean age of 35.20 $\pm 0.54 \mathrm{Ma}$ (Table A1). A short conference abstract by Obradovich et al. (1989) reported an age of $35.5 \pm 0.3 \mathrm{Ma}$ for North American tektites found in a drill-core obtained by ${ }^{40} \mathrm{Ar}-{ }^{39} \mathrm{Ar}$ step heating data. Because there is no specification on the age monitor used in that study, the reported age cannot be corrected for the updated age of the monitor sample used; consequently this age is not included in our revision of $\mathrm{CB}$ impact age from the combined data set. Kunk et al. (2009) reported an age range of $\sim 33$ to $\sim 47 \mathrm{Ma}$ using ${ }^{40} \mathrm{Ar}^{-39} \mathrm{Ar}$ step heating on orthoclase, muscovite and microcline extracted from material from the central moat of Chesapeake Bay crater. These ages could not be corrected due to lack of information regarding the age-monitor used in the study. Moreover, Kunk et al. (2009) did not report the full dataset and respective plots, therefore full evaluation of step heating experiments is not possible, e.g., presence of excess argon.

\section{Samples and Methods}

This work presents - for the first time - a comprehensive ${ }^{40} \mathrm{Ar}-{ }^{39} \mathrm{Ar}$ step heating data set for four North American tektites linked to the Chesapeake Bay impact structure, and glass portions extracted from the first two clast-rich impact melt rocks acquired within this impact structure. Contrary to total fusion gas extraction, the use of the step heating technique allows differential extraction of radiogenic, and atmospheric and/or inherited, and potentially other sources of argon (collectively denominated as excess) components within the specimen. In 
turn, the step-heating approach is ideal to correct for this potential trapped/excess ${ }^{40} \mathrm{Ar}$ and reliably determine a geologically meaningful age.

The step-heating analyses on tektites were carried out on core and rim aliquots prepared prior to irradiation. Two bediasite samples (Be281-A and Be281-B) were cut into core and rim fractions and each crushed to $\sim 1-2 \mathrm{~mm}$ diameter grains. Due to insufficient material to separate core and rim material, a third bediasite (Be283) and a georgiaite found by one of the co-authors (H. Povenmire) were analysed as bulk.

Two small slabs, one of the holocrystalline impact melt rock CB-W61 $(2.1 \times 0.7 \times 0.4 \mathrm{~cm}$, from $1404.96 \mathrm{~m}$ depth) and the other from the hypocrystalline impact melt rock CB-W84 $(2.05 \times 1.95 \times 0.7 \mathrm{~cm}$, from $1450.74 \mathrm{~m}$ depth) found in the ICDP-USGS Eyreville drill-core, and provided by A. Wittmann (now at Arizona State University, U.S.A.), were cut-off the faces where thin-section slices were taken and used by Wittmann et al. (2009) to conduct Scanning Electron Microscope (SEM) and identify the pristine glass. The impact melt groundmass samples extracted from these two these slabs were used for the step-heating ${ }^{40} \mathrm{Ar}^{-39} \mathrm{Ar}$ experiments described below.

Microscopically, CB-W84 exhibits some glassy, banded, isotropic and clear domains used for ${ }^{40} \mathrm{Ar}_{-}^{39} \mathrm{Ar}$ step heating experiments reported below. These clear domains contain $<100$ $\mu \mathrm{m}$-long, zoned orthopyroxene crystals of single-lath and dendritic morphologies, and euhedral, $\sim 5$ - $\mu \mathrm{m}$-wide spinel crystals. In $\sim 1$-mm-wide clear melt schlieren, brown, spherulitic, $\sim 100-\mu \mathrm{m}$-wide aggregates of radially intergrown aluminosilicate microphenocrysts are present (Figs. 3A-3D in Wittmann et al., 2009). The dark, aphanitic melt schlieren contain euhedral, $\sim 3$ - $\mu \mathrm{m}$-diameter Fe-Ti-O crystals, a few fan-like plagioclase phenocrysts, and small, equant quartz clasts in a smectitic groundmass.

Impact melt CB-W61 must have cooled comparatively slower, and thus, is fully crystallized. The clasts present in CB-W61 appear more assimilated by the melt groundmass, but abundant small, lithic fragments remain. Al-rich orthopyroxene of acicular and skeletal 
habits is partly corroded. The glassy portion of the melt used for the ${ }^{40} \mathrm{Ar}-{ }^{39} \mathrm{Ar}$ step heating crystallized mainly into radial laths of plagioclase that are locally intergrown with $\mathrm{SiO}_{2}$, and sometimes overgrown by cordierite.

Backscattered electron (BSE) images and chemical composition for four tektites, shown in Figures. 2 and 3, respectively, were obtained at the Museum für Naturkunde Berlin using a JEOL Superprobe JXA-8500F with online data reduction. Chemical composition data were obtained using a cup current of 15-20 nA, an acceleration potential of $15 \mathrm{keV}$, and an electron beam diameter of $2 \mu \mathrm{m}$. Peak counting time was 30s for most elements, with the exception of $\mathrm{Na}$, for which a counting time of 20 s was used, to minimize loss during measurements and Mn with a counting time of 40s. The background was evaluated for $15 \mathrm{~s}$ on either side of the peak.

Tektites and impact melts were analysed using the ${ }^{40} \mathrm{Ar}-{ }^{39} \mathrm{Ar}$ step-heating technique at the Klaus-Tschira-Labor für Kosmochemie, Institut für Geowissenschaften, Universität Heidelberg. Samples were exposed to neutron irradiation at the Portuguese Research Reactor (RPI) located at the Nuclear and Technologic Institute (ITN), Sacavém, Portugal. Two irradiation series were performed in order to check results of the first irradiation series by repeated analyses and using slightly different irradiation conditions. The first irradiation series included two aliquots for each of the three bediasite samples, where "c" stands for core and "r" stands for rim: bediasite Be281-A core samples Be281-Ac, Be281-Ac2, rim samples Be281-Ar, Be281-Ar2; bediasite Be281-B core samples Be281-Bc, Be281-Bc2, and rim samples Be281-Br, Be281-Br2; two bulk samples of bediasite Be283, Be283-1, Be283-2; one bulk aliquot of one georgiaite (Ge-1); and two bulk Chesapeake Bay impact melt samples CBW61, CB-W84. The second irradiation series included one piece of each of the two bulk impact melt samples (CB-W61-2, CB-W84-2), a second aliquot of the previously measured bulk georgiaite (Ge-2) and a third core sample of bediasite Be281-B (Be281-Bc3). Prior to each irradiation, impact melts, tektites and Bergell granodiorite biotite fluence monitors (HD- 
B1; 24.18 \pm 0.09 Ma; Schwarz and Trieloff, 2007) were wrapped in Al-foil and loaded into vacuum-sealed pure-silica vials. Cd-shielding was used to reduce isotopic interferences from thermal neutrons during irradiation at the RPI. Each sample was bracketed by two monitors in order to calculate J-values and neutron flux variation uncertainties (e.g. Schwarz and Trieloff, 2007). J-values per sample are given in the appendix Tables A4-A20; the errors of plateau, KAr and isochron ages (Table 1) include errors related to neutron flux uncertainty.

After irradiation, the samples were step heated in an inductively heated Mo-furnace up to $1750^{\circ} \mathrm{C}$. For each individual sample argon was extracted over $15-26$ steps (Tables A4-A20 and Table 1) by consecutively increasing the temperature by 20 to $150^{\circ} \mathrm{C}$. The gas was cleaned by hot $\left(400-600^{\circ} \mathrm{C}\right)$ and cold $\mathrm{Zr}$-Al- and Ti-getters. Argon isotopes were measured using a modified VARIAN MAT CH5 mass spectrometer. All argon data were corrected for mass discrimination (checked daily via calibration with gas of air composition), radioactive decay, isotopic interferences and blanks from the extraction line and furnace. The ${ }^{40} \mathrm{Ar}$ blank varied between $1 \cdot 10^{-9} \mathrm{~cm}^{3}$ at $800^{\circ} \mathrm{C}$ and $2 \cdot 10^{-8} \mathrm{~cm}^{3}$ at $1400^{\circ} \mathrm{C}$ for the first series, and $1 \cdot 10^{-10}$ $\mathrm{cm}^{3}$ at $800^{\circ} \mathrm{C}$ and $2 \cdot 10^{-9} \mathrm{~cm}^{3}$ at $1400^{\circ} \mathrm{C}$ for the second irradiated series. Both blanks had no measurable ${ }^{37} \mathrm{Ar}$ and ${ }^{39} \mathrm{Ar}$, and negligible mass spectrometer background. Blank series were usually measured in 5 consecutive temperature steps (i.e., from high to low temperature) prior to each sample insertion in the furnace to precisely correct the sample gas (see appendix Fig. A3). Applied blank values are an exponential fit by interpolating through these five temperature extractions. The argon isotopic composition of blank extractions was atmospheric within uncertainty.

Ages were calculated using K-Ar decay constants recommended by Steiger and Jäger (1977). Correction factors for interfering isotopes, based on data obtained from degassed $\mathrm{CaF}_{2}$ and a quaternary sanidine from the Käsegrotte volcanics in the Eifel region of Germany, were: $\left({ }^{36} \mathrm{Ar}{ }^{37} \mathrm{Ar}\right)_{\mathrm{Ca}}=(2.67 \pm 0.27) \cdot 10^{-4} ;\left({ }^{39} \mathrm{Ar} /{ }^{37} \mathrm{Ar}\right)_{\mathrm{Ca}}=(6.66 \pm 0.67) \cdot 10^{-4} ;\left({ }^{40} \mathrm{Ar} /{ }^{39} \mathrm{Ar}\right)_{\mathrm{K}}=(4 \pm 0.4) \cdot 10^{-4} ;$ $\left({ }^{38} \mathrm{Ar} /{ }^{39} \mathrm{Ar}\right)_{\mathrm{K}}=(1.21 \pm 0.01) \cdot 10^{-2}$ for the first irradiation series, and for the second irradiation 
series: $\left({ }^{36} \mathrm{Ar} /{ }^{37} \mathrm{Ar}\right)_{\mathrm{Ca}}=(2.65 \pm 0.08) \cdot 10^{-4} ;\left({ }^{39} \mathrm{Ar} /{ }^{37} \mathrm{Ar}\right)_{\mathrm{Ca}}=(6.72 \pm 0.34) \cdot 10^{-4} ;\left({ }^{40} \mathrm{Ar} /{ }^{39} \mathrm{Ar}\right)_{\mathrm{K}}=$ $(1.23 \pm 0.24) \cdot 10^{-2} ;\left({ }^{38} \mathrm{Ar} /{ }^{39} \mathrm{Ar}\right)_{\mathrm{K}}=(2.24 \pm 0.16) \cdot 10^{-2}$. Using more recent suggestions for $\mathrm{K}-\mathrm{Ar}$ decay constants, better enabling comparison with other age determination methods, calculated ${ }^{40} \mathrm{Ar} /{ }^{39} \mathrm{Ar}$ ages increase by about $1 \%$, for Mesozoic ages (Villeneuve et al., 2000; Renne et al., 2010 and 2011; Schwarz et al., 2011). Plateau ages (Table 1) were obtained by taking the portion of an age spectrum composed of contiguous gas extractions representing $\geq 50 \%$ of the total ${ }^{39} \mathrm{Ar}$ released (McDougall and Harrison, 1999). Plateau ages were calculated from these extractions as inverse variance weighted means with an additional weight for the ${ }^{39}$ Ar release.

The reported mean age values (e.g., table 2) were calculated as inverse variance weighted means, MSWD and P values using ISOPLOT (Ludwig, 2012). Isochron regressions were also performed using ISOPLOT. All age uncertainties shown in figures and tables are at the $2 \sigma$ level, unless stated otherwise. Uncertainties in brackets include the fluence monitor HD-B1 age uncertainty, $\mathrm{t}=24.18 \pm 0.09 \mathrm{Ma}$ (Schwarz and Trieloff, 2007).

Excess ${ }^{40} \mathrm{Ar}$ is a combination of atmospheric, inherited radiogenic ${ }^{40} \mathrm{Ar}$, and any other parentless ${ }^{40} \mathrm{Ar}\left({ }^{40} \mathrm{Ar}\right.$ that exists in the sample but with no relation to the $\mathrm{K}$ content of the sample) released during erosion of the target rock, e.g. from the $\sim 615$ Ma gneissic biotite granite prior to the impact event, but stored in the target rock complex. Evaluating this excess ${ }^{40} \mathrm{Ar}$ was one of the main aims of the project and the reason for carrying out step-heating argon extraction from both tektites commonly assigned to the Chesapeake Bay crater and the recently found first set of impact melt rocks. The ${ }^{40} \mathrm{Ar} /{ }^{36} \mathrm{Ar}$ ratio value for the excess component was evaluated using the y-intercept in the inverse isochron. This ${ }^{40} \mathrm{Ar} /{ }^{36} \mathrm{Ar}$ ratio value was used to correct each set of heating steps obtained for each analysed impactite sample. During, and immediately after the impact event, the environment is turbulent, and the isotopic composition of the gas in the system is feasibly not homogeneous. Consequently, the ${ }^{40} \mathrm{Ar} /{ }^{36} \mathrm{Ar}$ ratio of the trapped component cannot be assumed the same for all the Chesapeake Bay impactites. Hence, individual values for the trapped ${ }^{40} \mathrm{Ar}$ data correction were obtained 
for each sample using per-sample data regression. The y-intercept value is used to correct the age spectrum only if the trapped ${ }^{40} \mathrm{Ar} /{ }^{36} \mathrm{Ar}$ ratio is significantly different from atmospheric composition. If not, atmospheric composition is used. The age plateau should then correspond to the heating steps in the regression line from where the trapped values were derived.

\section{Results}

The BSE images of North American tektites and inclusions therein are shown in Fig. 2. Electron microprobe analyses (EMPA) for $\mathrm{MgO}, \mathrm{K}_{2} \mathrm{O}, \mathrm{CaO}$ and $\mathrm{Na}_{2} \mathrm{O}$ are displayed in Fig. 3 and all other main elements oxide weight percent are given in Appendix Tables A2 and A3. ${ }^{40} \mathrm{Ar} /{ }^{39} \mathrm{Ar}$ data for North American tektites and impact melt samples from the ICDP-USGS Eyreville drill-core section $\mathrm{B}$ are shown as ${ }^{40} \mathrm{Ar} /{ }^{39} \mathrm{Ar}$ apparent age and $\mathrm{K} / \mathrm{Ca}$ (derived from ${ }^{37} \mathrm{Ar}_{\mathrm{Ca}}{ }^{39} \mathrm{Ar}_{\mathrm{K}}$ ) spectra versus fractional ${ }^{39} \mathrm{Ar}$ release spectra and as inverse isochrons (i.e., ${ }^{36} \mathrm{Ar} /{ }^{40} \mathrm{Ar}$ vs. ${ }^{39} \mathrm{Ar} /{ }^{40} \mathrm{Ar}$ ) in Figs. 4-6. A summary of the results is given in Table 1, and the complete data set is presented in Appendix Tables A4-A20.

The plateau ages are based on consecutive intermediate and high temperature heating steps (53-99\% ${ }^{39} \mathrm{Ar}$ release) dominated by radiogenic ${ }^{40} \mathrm{Ar}$ as confirmed from respective inverse isochron plots. As shown below and in Table 1 and 2, the apparent ages for plateaux and inverse isochrons are consistent, and the samples have not experienced obvious secondary ${ }^{40} \mathrm{Ar}$ loss. While the tektites are overall devoid of an excess ${ }^{40} \mathrm{Ar}$ component, as determined from ${ }^{36} \mathrm{Ar} /{ }^{40} \mathrm{Ar}$ vs. ${ }^{39} \mathrm{Ar} /{ }^{40} \mathrm{Ar}$ plots (Figs. 4-6), some extractions at low and high temperatures indicate excess argon, e.g., sample Be281-Br (Fig. 4D), and have corresponding higher K-Ar age of $36.65 \mathrm{Ma}$. Excess argon is a combination of inherited radiogenic ${ }^{40} \mathrm{Ar}$ with atmospheric, and any trapped non-quantifiable argon component that may have existed in the turbulent environment after the impact event, e.g. derived from the degassing and weathering of the targeted rocks. Such an excess argon component was clearly evident for the Ar isotopes extracted from the melt portion of the two impact melt rocks. 


\subsection{SEM inspection and EMP analyses of tektites}

Inspection of tektite samples using BSE images and optical microscopy shows that these are composed of quenched glass but also include lithic clasts, microlites, devitrified melt spheres, and vesicles (Fig. 2). Furthermore, an inclusion within tektite Be281-A (Fig. 2c) shows an immiscibility texture between melts of different composition, appearing light and darker grey in the BSE images, with the brighter features representing cross-sections of 3D dendritic crystallites enriched in chlorine. This $\mathrm{Cl}$ may represent remnants of late-Eocene saline water, e.g., ocean water, as this crater formed in a marine environment.

Elemental composition analyses show variations between different tektites, potentially revealing moderate intra- and inter-tektite heterogeneities. The EMPA data (Fig. 3) shows that each tektite covers a limited range of chemical composition. Devitrified spherules of about $120 \mu \mathrm{m}$ diameter found within bediasite $\mathrm{Be} 281-\mathrm{B}$ show a larger $\mathrm{K}_{2} \mathrm{O}$ content than that of the glassy matrix of the tektite (star in Fig. $3 \mathrm{a}$ and $\mathrm{b}$ ) at $\sim 2.5$ to $\sim 3.2 \mathrm{wt} \%$. Nevertheless, the Krich spherules have a low $\leq 2$ vol\% modal abundance, and thus, a minor influence on the bulk K budget.

\section{$4.2{ }^{40} \mathrm{Ar}-{ }^{39} \mathrm{Ar}$ step heating analyses of tektites}

The argon isotopic composition of rim and core material was acquired over 15 to 26 heating steps from two bediasites (Be281-A and Be281-B), and bulk material from one bediasite (Be283), one georgiaite (Ge), and melt extracted from the groundmass of the two impact melt rocks CB-W61 and CB-W84, replicated (Figs. 4-6). Plateau and inverse isochron ages with respective Mean Square Weighted Deviation (MSWD) and Probability (P) values are shown in Table 1 and on the respective plots. Table 2 shows mean ages also in comparison with age values calculated with updated decay constants (Renne et al. 2010, 2011, Schwarz et al. 2011). The aim in studying bediasite rim and core samples separately is to 
evaluate whether argon is heterogeneously distributed within tektites, including the presence of either inherited excess ${ }^{40} \mathrm{Ar}$, or secondary ${ }^{40} \mathrm{Ar}$ loss. Material permitting, 2-3 aliquots were analysed to investigate the reproducibility of the results (Table 1).

In general, the argon age spectra of the tektites show well-defined age plateaux (we use plateaux instead of plateaus to follow the correct French spelling of the word) encompassing up to $99 \%$ of the fractional ${ }^{39} \mathrm{Ar}$ released. For all tektite aliquots analysed, the inverse isochron plots indicate atmospheric ${ }^{40} \mathrm{Ar} /{ }^{36} \mathrm{Ar}$ ratios within uncertainties, i.e., no evidence of excess ${ }^{40}$ Ar. However, in a few cases, relatively high apparent ages were observed along the initial $5-10 \%$ of the ${ }^{39} \mathrm{Ar}$ released, and also for high temperature extractions between 1500 and $1750^{\circ} \mathrm{C}$. These steps had relatively large uncertainties due to large blank corrections, indicating small amounts of excess argon. For example, these features occur in sample Be281$\mathrm{Br}$ (Fig. 4D), resulting in a higher total $\mathrm{K}-\mathrm{Ar}$ age of $36.65 \mathrm{Ma}$, which is equivalent to a total fusion age. Such extractions with high apparent ages in the initial Ar-extraction steps were rejected from plateau age calculations (Table 1). In general, the ages calculated from inverse isochrons agree within uncertainties with those obtained from plateaux (Table 1, Figs. 4-6), thus all corrections applied and ages obtained are considered reliable. The MSWD values generally lead to acceptable $\mathrm{P}$ values $>5 \%$, meaning that the selected step heating schedule for age determination resulted in apparent ages and respective uncertainties that are representative and with a meaningful statistical distribution. The displayed tektite spectra are corrected for trapped argon of atmospheric composition, as inverse isochron plots did not yield values significantly different from air (Table 1).

\subsubsection{Bediasite Be281-A}

Two aliquots of core and rim samples from bediasite Be281-A were analysed. Figs. 4A and B (Appendix Figures A1-A and A1-B) show the spectra and isochron plots of core and rim samples for this tektite (Table 1). The $\mathrm{K} / \mathrm{Ca}$ spectra are flat and similar for the subsamples. 
417 The ages calculated for each of the four plateaux comprise between 62 to $96 \%{ }^{39} \mathrm{Ar}$ release 418 from consecutive heating steps. These ages are indistinguishable within uncertainties, and vary from $34.23 \pm 0.54 \mathrm{Ma}(\mathrm{MSWD}=1.49, \mathrm{P}=0.11$; rim aliquot $\mathrm{Be} 281-\mathrm{Ar}$, Fig. 4B) to 33.28 \pm 0.71 Ma (MSWD=0.35, $\mathrm{P}=0.98$, rim aliquot Be281-Ar2, Fig. A1-B), while the isochron ages vary from $33.36 \pm 0.80 \mathrm{Ma}(\mathrm{MSWD}=0.64, \mathrm{P}=0.87$; Fig. $\mathrm{A} 1-\mathrm{B})$ and $34.49 \pm 0.82$ Ma (MSWD=1.01, $\mathrm{P}=0.44$; Fig. 4B). The calculated weighted mean age based on all four aliquots for this tektite (Table 2 and Fig. 7) is $33.83 \pm 0.66 \mathrm{Ma}$ (MSWD=1.7, $\mathrm{P}=0.16$ ) from plateaux, and 33.92 $\pm 0.84 \mathrm{Ma}(\mathrm{MSWD}=1.3, \mathrm{P}=0.27)$ for isochrons.

\subsubsection{Bediasite Be281- $B$}

Similar to above, argon was extracted from three core and two rim aliquots of sample Be281-B (Figs. 4C and D, Appendix Figs. A1-C and A1-D; Table 1). The K/Ca spectra are essentially flat, with high uncertainties, potentially due to the low amount of nucleogenic

${ }^{37} \mathrm{Ar}$, which was nearly decayed at the time of the measurements. Age plateaux comprised between $\sim 79$ and $\sim 98 \%$ of the total ${ }^{39} \mathrm{Ar}$ release. The plateau ages determined for the five aliquots range from $34.72 \pm 0.94 \mathrm{Ma}(\mathrm{MSWD}=0.65, \mathrm{P}=0.84)$ for core aliquot $\mathrm{Be} 281-\mathrm{Bc}$ (Fig. $\mathrm{A} 1-\mathrm{C})$ to $33.32 \pm 0.90 \mathrm{Ma}(\mathrm{MSWD}=1.07, \mathrm{P}=0.38)$ for the rim aliquot $\mathrm{Be} 281-\mathrm{Br} 2$ (Fig. A1-C), being all indistinguishable within uncertainties. The inverse isochron plots yield ages between 33.69 $\pm 0.82 \mathrm{Ma}(\mathrm{MSWD}=1.29, \mathrm{P}=0.21$; Fig. 4D) and $35.13 \pm 0.88 \mathrm{Ma}(\mathrm{MSWD}=0.82, \mathrm{P}=0.67$; Fig. A1-C). The error weighted mean of plateaux ages determined for this tektite (Table 2 and Fig. 7) is $34.27 \pm 0.49 \mathrm{Ma}(\mathrm{MSWD}=1.7, \mathrm{P}=0.14)$ and $34.54 \pm 0.28 \mathrm{Ma}(\mathrm{MSWD}=0.75, \mathrm{P}=0.56)$ for the inverse isochrons.

\subsubsection{Bediasite Be283}

The ${ }^{40} \mathrm{Ar}-{ }^{39} \mathrm{Ar}$ step heating data acquired for the two bulk Be283 tektite aliquots (Figure 4E, Fig. Appendix A1-E; Table 1) display flat $\mathrm{K} / \mathrm{Ca}$ spectra and flat age spectra yielding 
plateau ages of $34.45 \pm 0.66 \mathrm{Ma}(\mathrm{MWSD}=0.56, \mathrm{P}=0.87$; Fig. 4E) and $34.70 \pm 0.66 \mathrm{Ma}$ (MSWD=1.61, $\mathrm{P}=0.08$; Fig. $\mathrm{A} 1-\mathrm{E}$ ) and for $\mathrm{Be} 283-2$ and $\mathrm{Be} 283-1$, respectively. Inverse isochron ages are $34.67 \pm 0.66 \mathrm{Ma}(\mathrm{MSWD}=0.75, \mathrm{P}=0.72$; Fig. 4E) and $35.05 \pm 0.66 \mathrm{Ma}$ (MSDW=1.05, $\mathrm{P}=0.4$; Fig. A1-E), respectively. The mean age calculated for the plateaux derived for the two aliquots of the Be283 tektite (Table 2 and Fig. 7)is 34.57 $\pm 0.75 \mathrm{Ma}$ (MWSD $=0.29, \mathrm{P}=0.59$ ), and for isochrons is $34.86 \pm 0.76$ (MSWD=0.66, $\mathrm{P}=0.42$ ). These results agree within error with those obtained for tektites Be281-A and Be281-B.

\subsubsection{Georgiaite}

Two bulk georgiaite aliquots were analysed yielding plateau ages of $33.80 \pm 0.83 \mathrm{Ma}$ $\left(\mathrm{MSWD}=0.45, \mathrm{P}=0.96\right.$; Fig. 5) calculated over $82 \%$ of ${ }^{39} \mathrm{Ar}$ released, and of $34.82 \pm 0.85 \mathrm{Ma}$ (MSWD=1.79, $\mathrm{P}=0.04$; Fig. A2) calculated over $86 \%$ of ${ }^{39} \mathrm{Ar}$ released, with a mean age of 34.30 $\pm 1.03 \mathrm{Ma}$ (Table 1). The inverse isochron ages are $33.99 \pm 0.88 \mathrm{Ma}(\mathrm{MSWD}=0.84$, $\mathrm{P}=0.68)$ and $34.89 \pm 0.54 \mathrm{Ma}(\mathrm{MSWD}=1.10, \mathrm{P}=0.34)$, respectively, and with a mean of 34.64 $\pm 0.84 \mathrm{Ma}(\mathrm{MSWD}=3.0, \mathrm{P}=0.08$; Fig. 7 and Table 2). These results agree within error with those obtained for tektites Be281-A, Be281-B and Be283 as reported above.

Overall, the ${ }^{40} \mathrm{Ar}-{ }^{39} \mathrm{Ar}$ step-heating spectra of the North American tektites yielded well defined plateau and isochron ages, agreeing within their uncertainties (Fig. 7 and Table 2). For all tektites the mean plateau age is $34.22 \pm 0.29 \mathrm{Ma}(\mathrm{MSWD}=0.78, \mathrm{P}=0.51)$, and the mean isochron age is $34.53 \pm 0.25 \mathrm{Ma}(\mathrm{MSWD}=0.96, \mathrm{P}=0.41)$.

\subsection{ICDP-USGS Eyreville drill-core Impact melts CB-W61 and CB-W84}

The ${ }^{40} \mathrm{Ar}-{ }^{39} \mathrm{Ar}$ data acquired for two splits of the holocrystalline groundmass from impact melt rock CB-W61 (Fig. 6A) and for two splits of hypocrystalline ground mass extracted from impact melt rock CB-W84 (Fig. 6B) show complex release spectra. The amount of excess ${ }^{40} \mathrm{Ar}$ in each sample was evaluated individually and the data were corrected accordingly. The 
${ }^{40} \mathrm{Ar} /{ }^{36} \mathrm{Ar}$ intercept of $\mathrm{CB}-\mathrm{W} 61$ is $354.2 \pm 2.5$, while two distinct isochrones were identified for CB-W61-2 with ${ }^{40} \mathrm{Ar} /{ }^{36} \mathrm{Ar}$ intercept of $363.8 \pm 5.4$ and $327.2 \pm 6.3$. For CB-W84 the ${ }^{40} \mathrm{Ar} /{ }^{36} \mathrm{Ar}$ intercept is $332.0 \pm 7.3$, and for CB-W84-2 an indistinguishable intercept of $329.6 \pm 5.6$ was obtained. To better show the effect of this correction, both uncorrected (grey) and corrected (black) spectra are shown in Figs 6A and 6B.

Splits CB-W61 and CB-W61-2 show a non-uniform K/Ca spectrum suggestive of the existence of different argon carrier phases. The CB-W61-2 K/Ca ratio of the first heating steps is higher than in CB-W61 suggesting an additional argon carrier phase in the latter. The inverse isochron plots clearly show the presence of excess ${ }^{40} \mathrm{Ar}$ yielding ${ }^{40} \mathrm{Ar} /{ }^{36} \mathrm{Ar}$ values distinct from air. This is not surprising considering the complexities in texture and clast components of this impact melt rock as observed by Wittmann et al. (2009). For the first $\sim 45 \%$ of ${ }^{39}$ Ar release, the uncorrected age spectrum of impact melts CB-W61 and CB-W61 -2 (grey spectra in Fig. 6A) are affected by significant release of excess ${ }^{40} \mathrm{Ar}$ causing high apparent ages, but differently for each split. While in sample CB-W61 only one additional excess argon carrier phase was identified, in sample CB-W61-2 at least two phases: one phase released excess ${ }^{40} \mathrm{Ar}$ during the low temperature heating steps representing $\sim 47 \%$ of the ${ }^{39} \mathrm{Ar}$ release, and producing a non-constant $\mathrm{K} / \mathrm{Ca}$ increase. The other phase provided a different excess ${ }^{40} \mathrm{Ar}$ component that was released along the intermediate and high-temperature steps reflecting $\sim 53 \%$ of the ${ }^{39} \mathrm{Ar}$-release. This part of the spectrum shows lower apparent ages and a nearly constant $\mathrm{K} / \mathrm{Ca}$ ratio. When separating out low temperature steps from intermediatehigh temperature steps, two different slopes for the inverse isochrons are discriminated (Fig. 6A bottom row: isochron sample CB-W61-2, dark grey and black dashed-lines and symbols. Hence, when calculating the age for sample CB-W61-2 two initial values for the ${ }^{40} \mathrm{Ar} /{ }^{36} \mathrm{Ar}$ ratio have to be considered to correct the excess argon component. This correction yields a flat spectrum over $84 \%$ of ${ }^{39} \mathrm{Ar}$ released (see Fig 6A, sample CB-W61-2 dark grey and black boxes for age spectrum, and respective initial ${ }^{40} \mathrm{Ar} /{ }^{36} \mathrm{Ar}$ values). 
CB-W61 data comprise a linear correlation in ${ }^{36} \mathrm{Ar} /{ }^{40} \mathrm{Ar}$ vs. ${ }^{39} \mathrm{Ar} /{ }^{40} \mathrm{Ar}$ plot (Fig. 6A)

496

497

498

499

500

501

502

503

504

505

506

507

508

509

510

511

512

513

514

515

516

517

518

519

520

yielding an initial ${ }^{40} \mathrm{Ar} /{ }^{36} \mathrm{Ar}$ ratio of $354.2 \pm 2.5$, which is used to correct the corresponding age spectrum (black spectrum in Fig. 6A). Using the part of the spectrum with over $90 \%{ }^{39} \mathrm{Ar}$ released, an age of $32.75 \pm 2.20 \mathrm{Ma}$ is calculated, with an isochron age of $31.70 \pm 2.80 \mathrm{Ma}$ (Fig. 6A; Table 1). For sample CB-W61-2 two inverse isochrons can be calculated, with initial values of $363.8 \pm 5.4$ for initial low-temperature steps $5-11$, and a value of $327.3 \pm 6.3$ for the following intermediate and high temperature steps $12-21$, leading to isochron ages of $31 \pm 12$ and 37.50 $\pm 2.60 \mathrm{Ma}$, respectively. Using these ${ }^{40} \mathrm{Ar} /{ }^{36} \mathrm{Ar}$ initial values to correct the respective step-heating data used for the apparent age spectrum, an age of $35.93 \pm 5.31 \mathrm{Ma}$ (MSWD $=0.43, \mathrm{P}=0.98$ ) is obtained corresponding to $84 \%$ of ${ }^{39}$ Ar released.

Similarly, correction of impact melt splits for sample CB-W84 age spectra (Fig. 6B, Table 1) for excess ${ }^{40} \mathrm{Ar}$ with ${ }^{40} \mathrm{Ar} /{ }^{36} \mathrm{Ar}$ initial ratios of $332.0 \pm 7.3(\mathrm{CB}-\mathrm{W} 84)$ and $329.6 \pm 5.6$ (CBW84-2), yielding within uncertainty indistinguishable plateau ages of $36.83 \pm 2.40 \mathrm{Ma}$ $(\mathrm{MSWD}=0.38, \mathrm{P}=0.94)$ and $37.48 \pm 2.60 \mathrm{Ma}(\mathrm{MSWD}=1.13, \mathrm{P}=0.32)$ for the age spectra, with inverse isochron ages of $38.30 \pm 2.50 \mathrm{Ma}(\mathrm{MSWD}=1.60, \mathrm{P}=0.10)$ and $37.50 \pm 2.10 \mathrm{Ma}$ $\left(\mathrm{MSWD}=2.50, \mathrm{P}=1 \times 10^{-4}\right)$.

All impact melt rock ages agree within uncertainties with a mean age of $35.43 \pm 2.13 \mathrm{Ma}$ (plateau; $\mathrm{MSWD}=3.5, \mathrm{P}=0.06$ ) and 36.82 $\pm 3.81 \mathrm{Ma}$ (inverse isochron; $\mathrm{MSWD}=0.83, \mathrm{P}=0.36$ ), which is indistinguishable from the mean age for the North American tektites of $34.22 \pm 0.29$ $\mathrm{Ma}(\mathrm{MSWD}=0.78, \mathrm{P}=0.51)$ and $34.53 \pm 0.25(\mathrm{MSWD}=0.96,0.41)$ Ma for plateau and inverse isochrons, respectively (Table 1). When calculating mean ages, sample W84-2 was excluded due to its very low isochron $\mathrm{P}$ value. The age for the melt rocks slightly tends towards higher ages, this may be due to a small excess argon component not included in the isochron correction procedure, leading to slight older ages, which is not unusual for impact melts (e.g., Schwarz and Lippolt, 2014). 
In the present study ${ }^{40} \mathrm{Ar}-{ }^{39} \mathrm{Ar}$ step heating data were acquired on core, rim and bulk aliquots of four North American tektites and two bulk impact melt fragments from the ICDPUSGS Eyreville drill-core. The corrected plateau ages are either unaffected by secondary ${ }^{40} \mathrm{Ar}$ loss or other disturbances providing an age of $34.22 \pm 0.29 \mathrm{Ma}(\mathrm{MSWD}=0.78, \mathrm{P}=0.51)$ and a corresponding error weighted mean inverse isochron age of $34.53 \pm 0.25 \mathrm{Ma}$ (MSWD $=0.96$, $\mathrm{P}=0.41$ ) for the North American tektites (Table 2). The Chesapeake Bay impact melt samples have excess ${ }^{40} \mathrm{Ar}$, and the approach mentioned above (section 4.3) allowed to correct most of the cases. A mean of plateau ages of $35.43 \pm 2.13 \mathrm{Ma}(\mathrm{MWSD}=3.5, \mathrm{P}=0.06$; Table 1$)$ and an indistinguishable mean inverse isochron age of $36.82 \pm 5.81 \mathrm{Ma}(\mathrm{MSWD}=0.83, \mathrm{P}=0.36)$ were obtained from pristine impact melt groundmass extracted from impact melt rocks CB-W61 and CB-W84. These are the first radio-isotopic ages reported for impactites found within the Chesapeake Bay crater together with the first complete set of ${ }^{40} \mathrm{Ar} /{ }^{39} \mathrm{Ar}$ step-heating data obtained from North American tektites. Assuming North American tektites were generated by the impact that formed the Chesapeake Bay impact structure, an average age of $34.53 \pm 0.23$ Ma $(\mathrm{MSWD}=0.87, \mathrm{P}=0.43)$ is calculated when combining the tektite and impact melt rock inverse isochron ${ }^{40} \mathrm{Ar} /{ }^{39} \mathrm{Ar}$ step heating data (Table 2). The statistical error of $0.23 \mathrm{Ma}$ and the error in the age of HD-B1 monitor result in a combined error of $\pm 0.32 \mathrm{Ma}(2 \sigma)$. The impact age with full external error of decay constant uncertainties is $34.86 \pm 0.32 \mathrm{Ma}$ for the isochron mean age and $34.55 \pm 0.40 \mathrm{Ma}$ for the plateau mean age, and take into account recent decay constant revisions (Renne et al. 2010, 2011, Schwarz et al. 2011). Our preferred age for the

542 Chesapeake Bay impact event is $34.86 \pm 0.32 \mathrm{Ma}$ and should be the one quoted when comparing with ${ }^{40} \mathrm{Ar}-{ }^{39} \mathrm{Ar}$ data obtained using different age monitors. This younger age is an improvement for the age of $35.20 \pm 0.54 \mathrm{Ma}$ previously considered for the Chesapeake Bay crater (see literature data compilation in Table A1). 
Although our new data and the compiled average of previous data - statistically biased by the Horton and Izett (2005) total fusion Ar-Ar data - are marginally consistent, the nominal age difference of $<1$ My may be caused by systematic uncertainties. One possibility could be the presence of excess argon, which is not possible to estimate when performing one-step maximum-temperature total fusion ${ }^{40} \mathrm{Ar}-{ }^{39} \mathrm{Ar}$ measurements. While it appears that excess argon was of only minor importance in our samples, and we corrected for it in the impact melt rocks, excess argon can be present in much higher concentration in tektites, such as in indochinites and australites (e.g., Schwarz et al. 2016). It is possible that sometimes the excess argon components remain undetectable in internal isochron diagrams, especially at a level of $\sim 1-2 \%$ of the radiogenic argon component, compared to the nominal age of the sample (Schwarz et al. 2014). Because the ${ }^{40} \mathrm{Ar}-{ }^{39} \mathrm{Ar}$ total fusion technique does not allow the use of internal isochrons, it is more likely to fail in identifying the presence of excess argon.

For example, the total fusion data in Horton and Izett (2005) were obtained for 4 different Ma to $35.48 \pm 0.31 \mathrm{Ma}$ for single total fusion measurements (see Appendix Table A1) with mean ages of $35.01 \pm 0.05$ and $35.39 \pm 0.19 \mathrm{Ma}$ (uncertainties at a $2 \sigma$ level). These means are only consistent within three sigma uncertainty limits, showing the possibility of excess argon in some samples. This is in principle not unusual for impact melt rocks and tektites, where excess argon is effectively only noticeable in high-resolution step heating age spectra, e.g. for moldavites, Ries glasses or australasian tektites (Schwarz and Lippolt 2002, 2014, Di Vincenzo and Skala 2009, Schwarz et al. 2014, 2016).

A second explanation for the age discrepancy between the current new data and previous ${ }^{40} \mathrm{Ar}-{ }^{39} \mathrm{Ar}$ total fusion data could be related to the different standards used to monitor the neutron fluence. While in the present study the HD-B1 standard was used, Horton and Izett (2005) used Taylor Creek sanidine (TCs) as fluence monitor. These authors already noted that 571 a different value for TCs of $27.92 \mathrm{Ma}$, i.e., $28.32 \mathrm{Ma}$, would lead to an age reduction of 0.5 
Ma, a value much closer to the result reported in the present study. Although this TCs age is considered to be obsolete, highlighting the need for standards to be frequently calibrated not directly against each other, but tied to another standard by a complex chain of cross calibrations. Hence, a direct comparison and improvement of the HD-B1 and TCs standard intercalibration is recommended.

Another theme worth discussion is the pronounced occurrence of excess argon in impact melts. Thickness and cooling rates by conductive heat transfer for the impact melts CB-W61 and CB-W84 were reported by Wittmann et al. (2009): impact melt rock CB-W84 is about 1 $\mathrm{m}$ thick and cooled in 7 weeks, and impact melt rock CB-W61 is about $5 \mathrm{~m}$ thick and cooled in 4 years. The different cooling time for each impact melt sections does not affect the amount of radiogenic ${ }^{40} \mathrm{Ar}$ produced. However, this time interval and a temperature of the host rock above closure temperature are probably sufficient for argon to diffuse out of target rock clasts (e.g., $615 \pm 7$ Ma old gneissic granite or $254 \pm 3$ Ma old massive biotite granite; Horton et al., $2009 \mathrm{~b}$ ) into the melt, where it remained as excess ${ }^{40} \mathrm{Ar}$ with no relation to the chemistry of the rock, or the age of the melt. This excess argon, if not properly accounted for and subtracted from the total ${ }^{40} \mathrm{Ar}$ measured, leads to erroneous older ages. Considering that the use of the ${ }^{40} \mathrm{Ar}-{ }^{39} \mathrm{Ar}$ step-heating technique permits proper evaluation of different argon components in the sample, the present data set offers the best estimate for the age of the Chesapeake Bay impact event.

\section{Conclusions}

High resolution step heating ${ }^{40} \mathrm{Ar}-{ }^{39} \mathrm{Ar}$ ages were obtained for different North American tektites and melt extracted from clast-rich impact melt rocks found within the ICDP-USGS Eyreville drill-core from the Chesapeake Bay impact structure. The results are in agreement with the interpretation that the Chesapeake Bay impact cratering event produced the North American tektites. The mean isochron age of $34.86 \pm 0.25(0.34)(2 \sigma)$ Ma $(\mathrm{MSWD}=0.96$, 
$\mathrm{P}=0.41$ ) determined for the North American tektites and the total mean isochron age of $34.86 \pm 0.23(0.32)(2 \sigma) \mathrm{Ma}(\mathrm{MSWD}=0.87, \mathrm{P}=0.43)$ age for the Chesapeake Bay impact event (including the age of the Chesapeake Bay impact melts; Table 2) are within uncertainties consistent with, but nominally slightly younger than the average of the recalculated literature

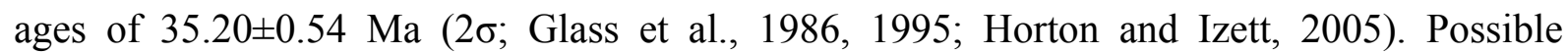
explanations include excess argon undetected by total fusion ${ }^{40} \mathrm{Ar}-{ }^{39} \mathrm{Ar}$ measurements, especially at low excess argon concentrations of only $\sim 1-2 \%$ of the radiogenic argon component, and insufficient inter-calibration of the HD-B1 and TCs standards.

Including the most recently suggested revision of the ${ }^{40} \mathrm{~K}$-decay constants (Renne et al. 2010, 2011; Schwarz et al. 2011), and a recalculated age 24.40+-0.18 Ma for the HD-B1 monitor used in this study, the data reported here for NA tektites and impact melt found within the ICDP-USGS Eyreville drill-core suggest an age of $34.86 \pm 0.23(0.32)(2 \sigma) \mathrm{Ma}$ for the Chesapeake Bay impact event. Concerning worldwide events recorded by the Massignano stratigraphic section (Fig. 8), two different scenarios are possible:

1) If the impact bolide caused an Ir-anomaly (e.g., the impactor was composed of Ir rich material, such as chondrites, primitive achondrites, stone-iron or iron meteorites), the Chesapeake Bay impact / North American tektite event possibly corresponds to the uppermost iridium layer at $10.28 \mathrm{~m}$ in the GSSP section at Massignano, Italy (Montanari et al., 1993; Bodiselitsch et al., 2004). As indicated by astronomical calibration (Jovane et al., 2006), the youngest of the three reported Ir-anomalies in the Massignano section precedes the E/O boundary by $1.12 \mathrm{My}$, which translates into an absolute age of $35.02 \pm 0.10 \mathrm{Ma}$, if the currently accepted ICS value of the E/O boundary of 33.9 $\pm 0.1 \mathrm{Ma}$ (Cohen et al. 2013) is applied. On the other hand, following the more recent estimate for the E/O boundary age of $34.09 \pm 0.08$ $(2 \sigma)$ Ma by Sahy et al. (2017), the age of this Ir-anomaly would be $35.21 \pm 0.10 \mathrm{Ma}$. This value is still consistent with the $34.86 \pm 0.32(2 \sigma)$ Ma weighted mean of age for the Chesapeake Bay 
impact event (Fig. 8). For the older iridium layer at Massignano (e.g., the 35.61 Ma old layer at $5.61 \mathrm{~m}$ ) the Chesapeake Bay impact event still appears too young.

2) If the Chesapeake Bay impact bolide did not cause an Ir-anomaly, e.g., the ejecta being strongly diluted in the sediments, or the projectile being an Ir-poor differentiated achondrite, this cratering event could be closer to, though only marginally coeval with, the E/O boundary at $34.09 \pm 0.08 \mathrm{Ma}$ (Sahy et al., 2017), Fig. 8, corresponding to the $\sim 19.22 \mathrm{~m}$ level of the GSSP section at Massignano, Italy.

This study has demonstrated that ${ }^{40} \mathrm{Ar}-{ }^{39} \mathrm{Ar}$ step heating is an indispensable analytical approach to date complex impactites produced from large meteorite impacts and the dynamic environment that results from such events where these impactites formed. Additionally, it is also important to perform complementary careful inspection of the samples using the SEM and EMPA techniques to evaluate potential contaminants, and sources of excess ${ }^{40} \mathrm{Ar}$, within both tektites and impact melt rocks. The age of $34.86 \pm 0.32(2 \sigma)$ Ma is suggested here as that of the event that formed the Chesapeake Bay crater, and it calls for re-establishing the stratigraphic and palaeo-magnetic correlations across the globe during the late-Eocene and early-Oligocene. Although it is probable that the Chesapeake Bay impact event affected life and environmental conditions in its vicinity, it may, however, not have been the inducer of the ice-house climatic change which was already taking place.

\section{Acknowledgments:}

VAF is grateful to Deutsche Forschungsgemeinschaft (DFG) for funding her to carry out this study through the ICDP special priority program, grant FE 1211/1-2, and to European Commission via a Marie Skłodowska Curie Fellowship, grant number 749815. MT, JH and WS thank Klaus Tschira Stiftung GmbH for financial support. We are grateful to I. Leya (University of Bern, Switzerland) for supplying bediasites Be281-A, Be281-B and Be283, and A. Wittmann (Washington University in St. Louis, U.S.A) for providing the essential material 
649 groundmass material from the impact melt rock for this research project. We very much

650 appreciate the reviews provided by Martin Schmieder, Fred Jourdan and Cameron Mercer, 651 which greatly helped in making the manuscript clearer and therefore more informative. We 652 are also appreciative for the editorial handling by Marc Norman and David Shuster. 
654

655

656

657

658

659

660

661

662

663

664

665

666

667

668

669

670

671

672

673

674

675

676

Albin E. F. and Wampler J. M. (1996) New potassium-argon ages for georgiaites and the upper Eocene Dry Branch Formation (Twiggs clay member) inferences about tektite stratigraphic occurrence. Proc. Lunar Sci. Conf. 27, 5-6.

Alvarez L. W., Alvarez W., Asaro F. and Michel H. V. (1980) Extraterrestrial cause for the Cretaceous-Tertiary extinction. Science 208, 1095-1108.

Artemieva N. A. and Morgan J. (2009) Modeling the formation of the K-Pg boundary layer. Icarus 201, 768-780.

Bodiselitsch B., Montanari A., Koeberl C. and Coccioni R. (2004) Delayed climate cooling in the late Eocene caused by multiple impacts; high-resolution geochemical studies at Massignano, Italy. Earth Planet. Sci. Lett. 223, 283-302.

Boschi S., Schmitz B., Heck P. R., Cronholm A., Defouilloy C., Kita N. T., Monechi S., Montanari A., Rout S. S. and Terfelt F. (2017) Late Eocene ${ }^{3} \mathrm{He}$ and $\mathrm{Ir}$ anomalies associated with ordinary chondritic spinels. Geochim. Cosmochim. Acta 204, 205-218.

Bottomley R., Grieve R., York D. and Masaitis V. (1997) The age of the Popigai impact event and its relation to events at the Eocene/Oligocene boundary. Nature 388, 365-368.

Catchings R. D., Powars D. S., Gohn G. S., Horton J. W. Jr., Goldman M. R. and Hole J. A. (2008) Anatomy of the Chesapeake Bay impact structure revealed by seismic imaging, Delmarva Peninsula, Virginia, USA: J. Geophys. Res. 113, B08413, doi:10.1029/2007JB005421.

Collins G. S. and Wünnemann K. (2005) How big was the Chesapeake Bay impact? Insight from numerical modeling. Geology 33, 925-928.

Cohen K. M., Finney S. C., Gibbard P. L. and Fan J.-X. (2013) The ICS International Chronostratigraphic Chart. Episodes 36, 199-204. 
677 Dalrymple G. B. and Duffield W. A. (1988) High-precision ${ }^{40} \mathrm{Ar} /{ }^{39} \mathrm{Ar}$ dating of Oligocene

678

679

680

681

682

683

684

685

686

687

688

689

690

691

692

693

694

695

696

697

698

699

700

701 rhyolites from the Mogollon-Datil volcanic field using a continuous laser system. Geophys. Res. Lett. 15, 463-466.

Deutsch A. and Koeberl C. (2006) Establishing the link between the Chesapeake Bay impact structure and the North American tektite strewn field: The Sr-Nd isotopic evidence. Meteor. Planet. Sci. 41, 689-703.

Di Vincenzo G. and Skála R. (2009) ${ }^{40} \mathrm{Ar}-{ }^{39} \mathrm{Ar}$ laser dating of tektites from the Cheb Basin (Czech Republic): Evidence for coevality with moldavites and influence of the dating standard on the age of the Ries impact. Geochim. Cosmochim. Acta 73, 493-513.

Edwards L. E., Powars D. S., Gohn G. S. and Dypvik H. (2009a) Geologic columns for the ICDP-USGS Eyreville A and B cores, Chesapeake Bay impact structure: Sediment-clast breccias, 1096 to 444 m depth. In: Gohn, G.S., Koeberl, C., Miller, K.G., Reimold, W.U. (Eds.), Geological Society Special Paper 458, 51-89.

Edwards L. E., Powars D. S., Browning J. V., McLaughlin P. P., Miller K. G., Self-Trail J. M., Kulpecz A. A., Elbra T. (2009b) Geologic columns for the ICDP-USGS Eyreville A and $\mathrm{C}$ cores, Chesapeake Bay impact structure: Postimpact sediments, 444 to $0 \mathrm{~m}$ depth. In: Gohn, G.S., Koeberl, C., Miller, K.G., Reimold, W.U. (Eds.), Geological Society Special Paper 458, 91-114.

Farley K. A., Montanari A., Shoemaker E. M. and Shoemaker C. S. (1998) Geochemical evidence for a comet shower in the late Eocene. Science 280, 1250-1253.

Ferrière L., Koeberl C. and Reimold W. U. (2009) Characterisation of ballen quartz and cristobalite in impact breccias: New observations and constraints on ballen formation: European J. Mineral. 21, 203-217.

Fleischer R. L. and Price P. B. (1964) Fission track evidence for the simultaneous origin of tektites and other natural glasses. Geochim. Cosmochim. Acta, 28, 755-760. 
Fleischer R. I., Price P. B. and Walker R. M. (1965) On the simultaneous origin of tektites and other natural glasses. Geochim. Cosmochim. Acta, 29, 161-166.

Fritz J., Tagle R. and Artemieva N. (2007) Lunar helium-3 in marine sediments: Implications for a late Eocene asteroid shower. Icarus 189, 591-594.

Garlick G. D., Naeser C. W. and O'Neil J. R. (1971) A Cuban tektite. Geochim. Cosmochim. Acta $35,731-732$.

Glass B. P., Baker R. N., Storzer D. and Wagner G. A. (1973) North American microtektites from the Caribbean Sea and their fission track age. Earth Planet. Sci. Lett. 19, 184-192.

Glass B. P., Hall C. M. and York D. (1986) ${ }^{40} \mathrm{Ar} /{ }^{39} \mathrm{Ar}$ laser-probe dating of North-American tektite fragments from Barbados and the age of the Eocene-Oligocene boundary. Chem. Geol. 59, 191-186.

Glass B. P., Koerbel C., Blum J. D., Senftle F., Izett G. A., Evans B.J., Thorpe A.N.,Povenmire H.and Strange R.L. (1995) A Muong-Nong type Georgia tektite. Geochim. Cosmochim. Acta, 59, 4071-4082.

Glass B. P. (2002) Upper Eocene impact ejecta/spherule layers in marine sediments. Chemie der Erde 62, 173-196.

Gohn G. S., Koeberl C., Miller K. G., Reimold W. U., Cockell C. S., Horton J. W., Sanford W. E. and Voytek M. A. (2006) Chesapeake Bay impact structure drilled: Eos (Transactions, American Geophysical Union) 87, 349-355.

Gohn G. S., Koeberl C., Miller K. G., Reimold W. U., Browning J. V., Cockell C. S., Horton J. W. Jr., Kenkmann T., Kulpecz A. A., Powars D. S., Sanford W.E. and Voytek M. A. (2008) Deep drilling into the Chesapeake Bay impact structure. Science 320, 1740-1745.

Gohn G. S., Koeberl C., Miller K. G. and Reimold W. U. (2009) Deep drilling in the Chesapeake Bay impact structure- An overview. In: Gohn, G.S., Koeberl, C., Miller, K.G., Reimold, W.U. (Eds.), Geological Society Special Paper 458, 1-20. 
Grüber R. and Mohr B. (2007) Deterioration and/or cyclicity? The development of vegetation and climate during the Eocene and Oligocene in Antarctica. U.S. Geological Survey and the National Academies; USGS OF-2007-1047, Extended Abstract 075.

Hildebrand A. R., Penfield G.T., Kring D. A., Pilkington M., Camargo Z. A., Jacobsen S. B. and Boynton W. V., 1991. Chicxulub crater: A possible Cretaceous/Tertiary boundary impact crater on the Yucatan Peninsula, Mexcico. Geology 19, 867.871.

Hilgen F. J., Kuiper K. F. (2009) A critical evaluation of the numerical age of the EoceneOligocene boundary. In Koeberl, C., Montanari, A. (Eds.), Geological Society Special Paper 452, 139-148.

Horton J. W. Jr. and Izett G.E. (2005) Crystalline-rock ejecta and shocked minerals of the Chesapeake Bay impact structure, USGS-NASA Langley Core, Hampton, Virginia, with Supplemental constraints on the age of Impact. In Horton, J. W., Jr., Powars, D. S., and Gohn, G. S., (Eds.), U.S. Geological Survey Professional Paper, E1-E30.

Horton J. W., Aleinikoff J. N., Kunk M. J., Jackson J. C., Belkin H. and Chou I.-M. (2007) Initial studies of breccias, blocks, and crystalline rocks in the ICDP-USGS Eyreville-B core, Chesapeake Bay impact structure, 1095-1766 m depth. Geol. Soc. of America Conf. $39,451$.

Horton J. W., Gibson R. L., Reimold W. U., Wittmann A., Gohn G. S. and Edwards L. E. (2009a) Geologic columns for the ICDP-USGS Eyreville B core, Chesapeake Bay impact structure: Impactites and crystalline rocks, 1766 to 1096 m depth. In Gohn, G.S., Koeberl C., Miller K.G., Reimold W.U. (Eds.), Geological Society of America Special Paper 458, 21-49.

Horton J. W. Jr., Kunk M. J., Belkin H. E., Aleinikoff J. N., Jackson J. C., Chou I.-M. (2009b) Evolution of crystalline target rocks and impactites in the Chesapeake Bay impact structure, ICDP-USGS Eyreville B core. In Gohn, G.S., Koeberl, C., Miller, K.G., Reimold, W.U. (Eds.) Geological Society of America Special Paper 458, 277-316. 
753

754

755

756

757

758

759

760

761

762

763

764

765

766

767

768

769

770

771

772

773

774

775

776

Jourdan F. and Renne P. (2007) Age calibration of the Fish Canyon sanidine ${ }^{40} \mathrm{Ar} /{ }^{39} \mathrm{Ar}$ dating standard using primary K-Ar standards. Geochim. Cosmochim. Acta 71, 387-402.

Jourdan F., Renne P. R. and Reimold W. U. (2009) An appraisal of the ages of terrestrial impact structures. Earth Planet. Sci. Lett. 286, 1-13.

Jovane L., Florindo F., Sprovieri M. and Palike H. (2006) Astronomic calibration of the late Eocene/early Oligocene Massignano section (central Italy), Geochem. Geophys. Geosyst. 7, Q07012.

Koeberl C., Poag C. W., Reimold W. U. and Brandt D. (1996) Impact origin of the Chesapeake Bay structure, and source of the North American tektites. Science 271, 12631266.

Korochantseva E. V., Trieloff M., Lorenz C. A., Buykin A. I., Ivanova M. A., Schwarz W. H., Hopp J. and Jessberger E. K. (2007) L-chondrite asteroid breakup tied to Ordovician meteorite shower by multiple isochron ${ }^{40} \mathrm{Ar}-{ }^{39} \mathrm{Ar}$ dating. Meteorit. Planet. Sci. 42, $113-$ 130.

Kunk M. J., Horton J. W. Jr. and McAleer R. J. (2009) ${ }^{40} \mathrm{Ar} /{ }^{39} \mathrm{Ar}$ dating results from the ICDP-USGS Eyreville B core: Constraints on the thermal history of the Chesapeake Bay impact structure. Geol. Soc. of America Conf. 41, 596.

Ludwig K. R. (2012) Isoplot-3.75, a geochronological toolkit for Microsoft Excel. Berkeley Geochronology Center Special Publication No. 5 (covers versions of Isoplot from 3.75 to 4.15), $75 \mathrm{pp}$.

Mak E. K. C., York D., Grieve R. A. F. and Dence M. R. (1976) The age of the Mistastin Lake crater, Labrador, Canada. Earth Planet. Sci. Lett. 31, 345-357.

McDougall I., Harrison M. T. (1999) Geochronology and thermochronology by the ${ }^{40} \mathrm{Ar} /{ }^{39} \mathrm{Ar}$ method, 2nd ed. Oxford: Oxford University Press. 269 p. 
Montanari A., Asaro F., Michel H. V. and Kennett J. P. (1993) Iridium anomalies of late Eocene age at Massignano (Italy), and ODP 689B (Maud Rise, Antarctic). Palaios 8, 420437.

Neukum G. and Ivanov B. A. (1994) Crater size distributions and impact probabilities on Earth from lunar, terrestrial planet, and asteroid cratering data. In Gehrels T. (Eds.), Hazards due to comets and asteroids, Univ. Arizona Press, Tucson, 359-416.

Obradovich J. D., Snee L. W. and Izett G. A. (1989) Is there more than one glassy impact layer in the late Eocene? Geol. Soc. of America Conf. 21, A134.

Poag C. W. and Commeau J. A. (1995) Paleocene to middle Miocene planctonic foraminifera of the southwestern Sailsbury Embayment, Virginia and Maryland: biostratigraphy, allostratigraphy, and sequence stratigraphy. J. Foramin. Res. 25, 135-155.

Poag C. W., Koeberl C. and Reimold W. U. (2004) The Chesapeake Bay impact craterGeology and geophysics of a late Eocene submarine impact structure: New York, Springer-Verlag, 522 p., plus CD-ROM.

Poag C. W. (2009) Paleoenvironmental recovery from the Chesapeake Bay bolide impact: The benthic foraminiferal record. In Gohn, G.S., Koeberl, C., Miller, K.G., and Reimold, W.U., (Eds.) Geological Society of America Special Paper 458, 747-774.

Pope K. O., Ocampo A. C., and Duller C. E., 1991. Mexican site for K/T impact crater. Nature, 352, 105.

Premoli-Silva I. and Jenkins D. G. (1993) Decision on the Eocene-Oligocene boundary stratotype. Episodes 16, 379-382.

Reimold W. U., Bartosova K., Schmitt R.-T., Hansen B., Crasselt C., Koeberl C., Wittmann, A. and Powars D.S. (2009) Petrographic observations on the Exmore breccia, ICDP-USGS Drilling at Eyreville, Chesapeake Bay impact Structure, USA.I, Gohn, G.S., Koeberl, C., Miller, K.G., and Reimold, W.U. (Eds.). Geological Society of America Special Paper 458, $655-698$. 
Renne P. R., Swisher C. C., Deino A. L., Karner D. B., Owens T. and Depaolo D. J. (1998) Intercalibration of standards, absolute ages and uncertainties in $40 \mathrm{Ar} / 39 \mathrm{Ar}$ dating. Chem. Geol. 145, 117-152.

Renne, P. R., Mundil R., Balco G., Min K. and Ludwig K. R. (2010) Joint determination of 40 $\mathrm{K}$ decay constants and ${ }^{40} \mathrm{Ar}^{*}{ }^{40} \mathrm{~K}$ for the Fish Canyon sanidine standard, and improved accuracy for ${ }^{40} \mathrm{Ar} /{ }^{39} \mathrm{Ar}$ geochronology. Geochim. Cosmochim. Acta 74, 5349-5367.

Renne P. R., Balco G., Ludwig K. R., Mundil R. and Min K. (2011) Response to the comment by W.H. Schwarz et al. on "Joint determination of ${ }^{40} \mathrm{~K}$ decay constants and ${ }^{40} \mathrm{Ar}^{*} /{ }^{40} \mathrm{~K}$ for the Fish Canyon sanidine standard, and improved accuracy for ${ }^{40} \mathrm{Ar} /{ }^{39} \mathrm{Ar}$ geochronology" by P.R. Renne et al. (2010). Geochim. Cosmochim. Acta 75, 5097-5100.

Sahy D., Condon D. J., Hilgen F. J. and Kuiper K. F. (2017) Reducing disparity in radio-isotopic and astrochronology based time scales of the late Eocene and Oligocene. Paleoceanography 32, 1018-1035.

Samson S. D. and Alexander E. C. (1987) Calibration of the interlaboratory ${ }^{40} \mathrm{Ar} /{ }^{39} \mathrm{Ar}$ dating standard MMhb-1. Chem. Geol. 66, 27-34.

Schmitz B., Harper D. A. T., Peucker-Ehrenbrink B., Stouge S., Alwmark C., Cronholm A., Bergstrom S. M., Tassinari M. and Xiaofeng W-F. (2008) Asteroid breakup linked to the great Ordovician biodiversification event. Nature Geosci. 1, 49-53.

Schulte P., Wade B.S., Kontny A. and Self-Trail J. M. (2009) The post-impact EoceneOligocene sedimentary record in the Chesapeake Bay impact structure: Implications for climate and sea-level changes on the Western Atlantic margin. In Gohn, G.S., Koeberl, C., Miller, K.G., Reimold, W.U. (Eds.) Geological Society of America Special Paper 458, 839-865.

Schulte P., Alegret L., Arenillas I., Arz J. A., Barton P. J., Bown P. R., Bralower T. J., Christeson G. L., Claeys Ph., Cockell C. S., Collins G. S., Deutsch A., Goldin T. J., Goto K., Grajales-Nishimura J. M., Grieve, R. A.., Gulick S. P. S., Johnson K. R., Kiessling W., 

V., Neal C. R., Nichols D. J., Norris R. D., Pierazzo E., Ravizza G., Rebolledo-Vieyra M., Reimold W. U., Robin E., Salge T., Speijer R. P., Sweet A.R., Urrutia-Fucugauchi J., Vajda V., Whalen M. T. and Willumsen P. S. (2010) The Chicxulub asteroid impact and mass extinction at the Cretaceous-Paleogene boundary. Science 327, 1214-1218.

Schwarz W. H., Lippolt H. J. (2002) Coeval argon-40/argon-39 ages of moldavites from the Bohemian and Lusatian strewn fields. Meteorit. Planet. Sci. 37, 1757-1763.

Schwarz W. H. and Trieloff M. (2007) Intercalibration of ${ }^{40} \mathrm{Ar}-{ }^{39} \mathrm{Ar}$ age standards NL-25, HB3gr hornblende, GA1550, SB-3, HD-B1 biotite and BMus/2 muscovite. Chem. Geol. $242,218-231$.

Schwarz W. H., Kossert K., Trieloff M. and Hopp J. (2011) Comment on the "Joint determination of ${ }^{40} \mathrm{~K}$ decay constants and ${ }^{40} \mathrm{Ar}^{*} /{ }^{40} \mathrm{~K}$ for the Fish Canyon sanidine standard, and improved accuracy ${ }^{40} \mathrm{Ar} /{ }^{39} \mathrm{Ar}$ geochronology" by Paul R. Renne et al. 2010. Geochim. Cosmochim. Acta 75, 5094-5096.

Schwarz W. H. and Lippolt H. J. (2014) ${ }^{40} \mathrm{Ar}^{39} \mathrm{Ar}$ step heating of impact glasses from the Nördlinger Ries impact crater. Meteorit. Planet. Sci. 49, 1023-1036.

Schwarz W. H., Trieloff M., Bollinger K., Gantert N., Fernandes V. A., Meyer H. P., Povenmire H., Jessberger E. K. and Koeberl C. (2016) Coeval ages of Australasian, Central American and Western Canadian tektites reveal multiple impacts 790 ka ago. Geochim. Cosmochim. Acta, 178, 307-319.

Self-Trail J. M., Edwards L. E., Litwin R. J. (2009) Paleontological interpretations of crater processes and infilling of synimpact sediments from the Chesapeake Bay impact structure. In Gohn, G.S., Koeberl C., Miller K.G., and Reimold W.U. (Eds.), Geological Society of America Special Paper 458, 633-654.

Steiger R. H. and Jäger E. (1977) Subcommission on geochronology: convention of the use of decay constants in geo- and cosmochronology. Earth Planet. Sci. Lett. 36, 359-362. 
Storzer D. and Wagner G. A. (1971) Fission track ages of North American tektites. Earth Planet. Sci. Lett. 10, 435-440.

Storzer D. and Wagner G. A. (1979) Fission track dating of Elgygytgyn, Popigai and Zhamanshin impact craters: No sources for Australasian or North-American tektites. Meteoritics 14, 541.

Tagle R. and Claeys P. (2004) Comet or asteroid shower in the late Eocene? Science 305, 492.

Villeneuve M., Sandeman H.A. and Davis W. J. (2000) A method for intercalibration of U$\mathrm{Th}-\mathrm{Pb}$ and ${ }^{40} \mathrm{Ar} /{ }^{39} \mathrm{Ar}$ ages in the Phanerozoic. Geochim. Cosmochim. Acta 64, 4017-4030.

Winzer S. R., Lum R. K. L. and Schuhmann S. (1976) Rb, Sr \& strontium isotopic composition, K/Ar age \& large ion lithophile trace element abundances in rocks \& glasses from the Wanapitei Lake impact structure. Geochim. Cosmochim. Acta 40, 51-57.

Wittmann A., Schmitt R. T., Hecht L., Kring D. A., Reimold W. U. and Povenmire H. (2009b) Petrology of impact melt rocks from the Chesapeake Bay crater, USA. In Gohn G.S., Koeberl C., Miller K.G., Reimold W.U. (Eds.) Geological Society of America Special Paper 458, 377-396.

Zachos J, Pagani M., Sloan L., Thomas E. and Billups K. (2001) Trends, rhythms, and aberrations in global climate 65 Ma to present. Nature 292, 686-693. 
Figure 1 Modified map after Gohn et al. (2006) and Horton et al. (2009a) showing the location of the International Continental Scientific Drilling Program (ICDP)-U.S. Geological Survey (USGS) Eyreville drill site in the Chesapeake Bay impact structure, $9 \mathrm{~km}$ from the centre of the impact structure.

880

Figure 2 Back-scattered electron (BSE) images of Chesapeake Bay related tektite BE281A:

882

883

a) spherule embedded in the bediasite showing partly crystalline glassy inclusions (microlites) with dendritic texture; b) close-up of the partly crystalline glassy inclusion showing devitrification; c) oblong melt particle with cross-sections of 3D dendritic Cl-rich crystallites in a different area of the bediasite; d) vesicles of different sizes in the georgiaite tektite used in this study.

Figure 3 Electron microprobe analyses obtained for three bediasites and for inclusions found within these tektites: a) $\mathrm{K}_{2} \mathrm{O}$ vs. $\mathrm{MgO}$ and b) $\mathrm{CaO}$ vs. $\mathrm{Na}_{2} \mathrm{O}$. Data in wt $\%$.

Figure $4 \mathrm{~A}^{40} \mathrm{Ar}-{ }^{39} \mathrm{Ar}$ results obtained for a core aliquot of bediasite Be281-A (Be281-Ac); s hown are age and $\mathrm{K} / \mathrm{Ca}$ spectra (left graphs), and inverse isochron diagrams (right graph). Error boxes correspond to $1 \sigma$ uncertainty, errors of age and ${ }^{40} \mathrm{Ar} /{ }^{36} \mathrm{Ar}$ initial values are $2 \sigma$.

Figure 4B ${ }^{40} \mathrm{Ar}-{ }^{39} \mathrm{Ar}$ results obtained for a rim aliquot of bediasite Be281-A (Be281-Ar); shown are age and $\mathrm{K} / \mathrm{Ca}$ spectra (left graphs), and inverse isochron diagrams (right graph). Error boxes correspond to $1 \sigma$ uncertainty, errors of age and ${ }^{40} \mathrm{Ar} /{ }^{36} \mathrm{Ar}$ initial values are $2 \sigma$. 
899 Figure $4 \mathrm{C}^{40} \mathrm{Ar}-{ }^{39} \mathrm{Ar}$ results obtained for a core aliquot of bediasite $\mathrm{Be} 281-\mathrm{B}(\mathrm{Be} 281-\mathrm{Bc})$; 900 shown are age and $\mathrm{K} / \mathrm{Ca}$ spectra (left graphs), and inverse isochron diagrams (right graph). 901 Error boxes correspond to $1 \sigma$ uncertainty, errors of age and ${ }^{40} \mathrm{Ar} /{ }^{36} \mathrm{Ar}$ initial values are $2 \sigma$.

902

903 Figure 4D ${ }^{40} \mathrm{Ar}^{39}{ }^{3} \mathrm{Ar}$ results obtained for a rim aliquot of bediasite $\mathrm{Be} 281-\mathrm{B}(\mathrm{Be} 281-\mathrm{Br} 2)$; 904 shown are age and $\mathrm{K} / \mathrm{Ca}$ spectra (left graphs), and inverse isochron diagrams (right graph).

905

906

907

908

909

910

911

912

913

914

915

916

917

918

919

920

921

922

923

924

Figure $5{ }^{40} \mathrm{Ar}-{ }^{39} \mathrm{Ar}$ results obtained for bulk aliquot of georgiaite tektite (Ge-1 and Ge-2); shown are age and $\mathrm{K} / \mathrm{Ca}$ spectra (left graphs), and inverse isochron diagrams (right graphs). Error boxes correspond to $1 \sigma$ uncertainty, errors of age and ${ }^{40} \mathrm{Ar} /{ }^{36} \mathrm{Ar}$ initial values are $2 \sigma$.

Figure 6A ${ }^{40} \mathrm{Ar}-{ }^{39} \mathrm{Ar}$ results for both aliquots of bulk impact melt rock samples $\mathrm{CB}-\mathrm{W} 61$ (CB-W61 and CB-W61-2) obtained from the USGS-ICDP Eyreville drill-core. Presented are age and $\mathrm{K} / \mathrm{Ca}$ spectra (top graphs), and inverse isochron diagrams (bottom graphs). The grey spectra correspond to an initial ${ }^{40} \mathrm{Ar} /{ }^{36} \mathrm{Ar}$ value of $295.5 \pm 0.5$ (Steiger and Jäger, 1977) and the dark grey/black spectrum corresponds to apparent ages corrected for trapped ${ }^{40} \mathrm{Ar} /{ }^{36} \mathrm{Ar}=$ $354.2 \pm 2.5$ (CB-W61) and 363.8 $\pm 5.4 / 327.3 \pm 6.3$ (CB-W61-2) values obtained from the y-axis intercept of the inverse isochron graph. Light grey symbols are excluded from isochron calculation. Error boxes correspond to $1 \sigma$ uncertainty, errors of age and ${ }^{40} \mathrm{Ar} /{ }^{36} \mathrm{Ar}$ initial values are $2 \sigma$. 
926 Figure $6 \mathrm{~B}^{40} \mathrm{Ar}-{ }^{39} \mathrm{Ar}$ results for both aliquots of bulk impact melt rock samples $\mathrm{CB}-\mathrm{W} 84$ 927 (CB-W84 and CB-W84-2) obtained from the USGS-ICDP Eyreville drill-core. Presented are

928

929

930

931

932

933

934

935

936

937

938

939

940

941

942

943

944

945

946 age and $\mathrm{K} / \mathrm{Ca}$ spectra (top graphs), and inverse isochron diagrams (bottom graphs). The grey spectrum corresponds to an initial ${ }^{40} \mathrm{Ar} /{ }^{36} \mathrm{Ar}$ value of $295.5 \pm 0.5$ (Steiger and Jäger, 1977) and the black spectrum corresponds to apparent ages corrected for trapped ${ }^{40} \mathrm{Ar} /{ }^{36} \mathrm{Ar}=332.0 \pm 7.3$ (CB-W84) and 329.6 \pm 5.6 (CB-W84-2). Light grey symbols are excluded from isochron calculation. Error boxes correspond to $1 \sigma$ uncertainty, errors of age and ${ }^{40} \mathrm{Ar} /{ }^{36} \mathrm{Ar}$ initial values are $2 \sigma$.

Figure 7 Summary of ${ }^{40} \mathrm{Ar}-{ }^{39} \mathrm{Ar}$ results. Left: summary of ${ }^{40} \mathrm{Ar}-{ }^{39} \mathrm{Ar}$ plateau ages; right: summary of ${ }^{40} \mathrm{Ar}-{ }^{39} \mathrm{Ar}$ inverse isochron ages. Open symbols represent single measurements; filled symbols are mean values for aliquots of NA tektites/Chesapeake Bay melt samples; dashed lines represent error weighted mean and its assigned uncertainty of all samples. All uncertainties represent $2 \sigma$ uncertainty limits

Figure 8 Comparison of Chesapeake Bay impact structure impactatite ages obtained in this study (tektites $=34.86 \pm 0.34 \mathrm{Ma}$, impact melts $=37.16 \pm 3.85 \mathrm{Ma}$, and tektites\&melts $=$ 34.86 $\pm 0.32 \mathrm{Ma}$ ) with a) Eocene/Oligocene boundary age: $33.9 \pm 0.1 \mathrm{Ma}$ (Cohen et al., 2013) and the $34.09 \pm 0.08 \mathrm{Ma}$ (Sahy et al., 2017), and b) the ages from the younger at $(10.28 \mathrm{~m})$ and older $(5.61 \mathrm{~m})$ iridium layers found in the GSSP section at Massignano, Italy (Montanari et al., 1993; Bodiselitsch et al., 2004). 
Table 1 Summary of ${ }^{40} \mathrm{Ar} /{ }^{39} \mathrm{Ar}$ step heating data obtained for bediasites Be281-A, Be281-B, Be283, georgiaites, and melt groundmass extracted from clast-rich impact melt rocks, CB-W61 and CB-W84, found in the ICDP-USGS Eyreville drill core. Errors shown at $2 \sigma$ level of uncertainty. Errors for plateau, K-Ar and isochron ages include neutron flux uncertainty. Ages calculated with Steiger and Jäger (1977) values for the ${ }^{40} \mathrm{~K}$ decay constants. Age averages at the bottom of the table are error weighted means. * denotes samples from the second irradiation series.

\begin{tabular}{|c|c|c|c|c|c|c|c|c|c|c|c|}
\hline Sample & $\begin{array}{c}\text { Weight } \\
{[\mathrm{mg}]}\end{array}$ & $\begin{array}{c}\text { Temp range } \\
\text { for plat. } \\
{\left[{ }^{\circ} \mathrm{C}\right]}\end{array}$ & $\begin{array}{l}\%{ }^{39} \\
\mathrm{Ar} \\
\text { rel. }\end{array}$ & $\begin{array}{c}\text { Plateau age } \\
{[\mathrm{Ma}]}\end{array}$ & $\begin{array}{l}\text { MS } \\
\text { WD }\end{array}$ & $\mathrm{P}$ & $\begin{array}{c}\text { inverse } \\
\text { isochron age } \\
{[\mathrm{Ma}]}\end{array}$ & $\begin{array}{c}\text { MSW } \\
\text { D }\end{array}$ & $\mathrm{P}$ & $\begin{array}{c}\text { Total } \mathrm{K}-\mathrm{Ar} \\
\text { age } \\
{[\mathrm{Ma}]}\end{array}$ & $\begin{array}{l}{ }^{40} \mathrm{Ar} /{ }^{36} \mathrm{Ar} \\
\text { intercept }\end{array}$ \\
\hline Be281-Ac & 214.9 & $900-1700$ & 96 & $33.81 \pm 0.91$ & 1.46 & 0.10 & $33.98 \pm 0.88$ & 0.81 & 0.68 & $33.73 \pm 0.91$ & $297 \pm 13$ \\
\hline Be281-Ac2 & 76.00 & $800-1400$ & 85 & $33.35 \pm 1.33$ & 1.22 & 0.27 & $33.88 \pm 0.92$ & 1.17 & 0.29 & $32.55 \pm 1.25$ & $293.9 \pm 1.6$ \\
\hline Be281-Ar & 229.2 & $960-1700$ & 94 & $34.23 \pm 0.54$ & 1.49 & 0.11 & $34.49 \pm 0.82$ & 1.01 & 0.44 & $34.08 \pm 0.45$ & $300.9 \pm 2.8$ \\
\hline Be281-Ar2 & 124.3 & $1000-1500$ & 62 & $33.28 \pm 0.71$ & 0.35 & 0.98 & $33.36 \pm 0.80$ & 0.64 & 0.87 & $33.06 \pm 1.11$ & $299.8 \pm 3.2$ \\
\hline $\mathrm{Be} 281-\mathrm{Bc}$ & 218.1 & $900-1700$ & 94 & $34.72 \pm 0.94$ & 0.65 & 0.84 & $35.13 \pm 0.88$ & 0.82 & 0.67 & $34.55 \pm 0.93$ & $295.7 \pm 2.7$ \\
\hline $\mathrm{Be} 281-\mathrm{Bc} 2$ & 127.6 & $1050-1420$ & 79 & $34.49 \pm 0.91$ & 1.57 & 0.09 & $34.75 \pm 0.88$ & 0.90 & 0.58 & $34.69 \pm 0.98$ & $304.3 \pm 4.0$ \\
\hline $\mathrm{Be} 281-\mathrm{Bc} 3 *$ & 109.2 & $960-1750$ & 98 & $34.57 \pm 0.63$ & 1.00 & 0.46 & $34.78 \pm 0.49$ & 1.17 & 0.26 & $34.69 \pm 0.63$ & $296 \pm 10$ \\
\hline $\mathrm{Be} 281-\mathrm{Br}$ & 163.5 & $960-1600$ & 84 & $33.94 \pm 0.95$ & 0.99 & 0.45 & $34.19 \pm 0.84$ & 1.07 & 0.38 & $36.65 \pm 1.55$ & $301.9 \pm 4.5$ \\
\hline $\mathrm{Be} 281-\mathrm{Br} 2$ & 138.2 & $900-1700$ & 94 & $33.32 \pm 0.90$ & 1.07 & 0.38 & $33.69 \pm 0.82$ & 1.29 & 0.21 & $33.28 \pm 0.86$ & $296.2 \pm 3.4$ \\
\hline Be283-1 & 95.10 & $800-1700$ & 99 & $34.70 \pm 0.66$ & 1.61 & 0.08 & $35.05 \pm 0.66$ & 1.05 & 0.40 & $34.59 \pm 0.47$ & $299.8 \pm 4.0$ \\
\hline Be283-2 & 139.4 & $960-1700$ & 91 & $34.45 \pm 0.66$ & 0.56 & 0.87 & $34.67 \pm 0.66$ & 0.75 & 0.72 & $34.38 \pm 0.57$ & $296.3 \pm 2.6$ \\
\hline GE-1 & 48.90 & $800-1360$ & 86 & $34.82 \pm 0.85$ & 1.79 & 0.04 & $34.89 \pm 0.54$ & 1.10 & 0.34 & $33.45 \pm 2.15$ & $294.8 \pm 1.3$ \\
\hline GE-2* & 109.7 & $1000-1620$ & 82 & $33.80 \pm 0.83$ & 0.45 & 0.96 & $33.99 \pm 0.88$ & 0.84 & 0.68 & $33.93 \pm 0.78$ & $304.0 \pm 5.4$ \\
\hline CB-W61 & 335.2 & $740-1400$ & 90 & $32.75 \pm 2.20$ & 1.32 & 0.17 & $31.70 \pm 2.80$ & 1.45 & 0.09 & $29.75 \pm 7.05$ & $354.2 \pm 2.5$ \\
\hline CB-W61-2* & 100.9 & $\begin{array}{c}830-1040 \\
1070-1400\end{array}$ & 84 & $35.93 \pm 5.31$ & 0.43 & 0.98 & $\begin{array}{r}31.00 \pm 12.00 \\
37.50 \pm 2.60\end{array}$ & 1.70 & 0. & - & $\begin{array}{r}363.8 \pm 5.4 \\
327.3 \pm 6.3\end{array}$ \\
\hline CB-W84 & 137.6 & $650-1150$ & 83 & $36.83 \pm 2.40$ & 0.38 & 0.94 & $38.30 \pm 2.50$ & 1.60 & 0.10 & $37.45 \pm 2.00$ & $332.0 \pm 7.3$ \\
\hline CB-W84-2* & 93.6 & $600-1350$ & 96 & $37.48 \pm 2.60$ & 1.13 & 0.32 & $37.50 \pm 2.10$ & 2.50 & $1 \cdot 10^{-4}$ & $35.11 \pm 4.82$ & $329.6 \pm 5.6$ \\
\hline
\end{tabular}


Table 2 Mean ages for ${ }^{40} \mathrm{Ar} /{ }^{39} \mathrm{Ar}$ dating results of bediasites Be281-A, Be281-B, Be283, georgiaite, and impact melt rock groundmass samples CBW61 and CB-W84. Mean ages are error weighted means with 2 $\sigma$ level of uncertainty. Results shown for Steiger and Jäger (1977) and Renne et al. (2011) values of the ${ }^{40} \mathrm{~K}$ decay constants. Age error in brackets includes additional error from the age monitor.

\begin{tabular}{|c|c|c|c|c|c|c|c|c|c|}
\hline Sample & $\begin{array}{c}\text { No. of } \\
\text { samples }\end{array}$ & $\begin{array}{c}\text { Mean plateau age } \\
{[\mathrm{Ma}]}\end{array}$ & & MSWD & $\mathrm{P}$ & $\begin{array}{c}\text { inverse } \\
\text { isochron age } \\
{[\mathrm{Ma}]} \\
\end{array}$ & & MSWD & $\mathrm{P}$ \\
\hline & & $\begin{array}{l}\text { Steiger \& Jäger } \\
\text { (1977) convention }\end{array}$ & $\begin{array}{l}\text { Renne et al. } \\
\text { (2011) }\end{array}$ & & & $\begin{array}{l}\text { Steiger \& Jäger } \\
\text { (1977) convention }\end{array}$ & $\begin{array}{l}\text { Renne et al. } \\
\text { (2011) }\end{array}$ & & \\
\hline Be281-A & 4 & $33.83 \pm 0.66(0.70)$ & & 1.7 & 0.16 & $33.92 \pm 0.84(0.86)$ & & 1.3 & 0.27 \\
\hline Be281-B & 5 & $34.27 \pm 0.49(0.56)$ & & 1.7 & 0.14 & $34.54 \pm 0.28(0.37)$ & & 0.75 & 0.56 \\
\hline $\mathrm{Be} 283$ & 2 & $34.57 \pm 0.75(0.78)$ & & 0.29 & 0.59 & $34.86 \pm 0.78(0.81)$ & & 0.66 & 0.42 \\
\hline GE & 2 & $34.30 \pm 1.03(1.03)$ & & 2.9 & 0.09 & $34.64 \pm 0.84(0.86)$ & & 3.0 & 0.08 \\
\hline Tektite mean & 4 & $34.22 \pm 0.29(0.38)$ & $34.54 \pm 0.29(0.38)$ & 0.78 & 0.51 & $34.53 \pm 0.25(0.34)$ & $34.86 \pm 0.25(0.34)$ & 0.96 & 0.41 \\
\hline CB-W61 & 2 & $33.20 \pm 3.02(3.02)$ & & 1.2 & 0.27 & $34.81 \pm 5.81(5.81)$ & & 9.2 & 0.002 \\
\hline CB-W84 & 1 & $37.48 \pm 2.60(2.60)$ & & & & $38.30 \pm 5.00(5.00)$ & & 1.60 & 0.10 \\
\hline $\begin{array}{l}\text { Melt rock } \\
\text { mean }\end{array}$ & 2 & $35.43 \pm 2.13(2.13)$ & $34.76 \pm 2.15(2.15)$ & 3.5 & 0.06 & $36.82 \pm 3.81(3.81)$ & $37.16 \pm 3.85$ (3.85) & 0.83 & 0.36 \\
\hline Total mean & 5 & $34.23 \pm 0.27(0.36)$ & $34.55 \pm 0.27(0.36)$ & 0.66 & 0.62 & $34.53 \pm 0.23(0.32)$ & $34.86 \pm 0.23(0.32)$ & 0.87 & 0.43 \\
\hline
\end{tabular}




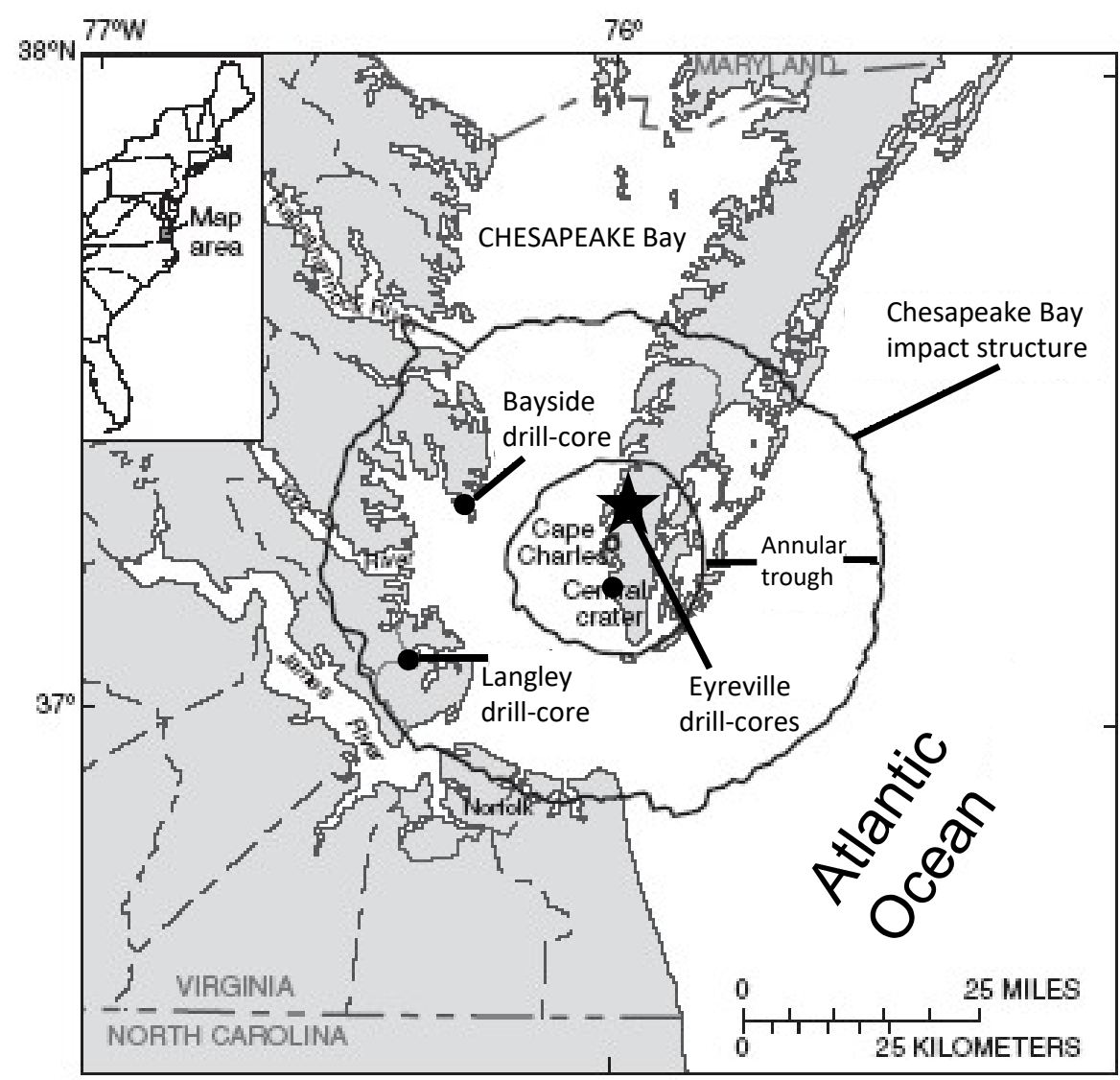

Figure 1 

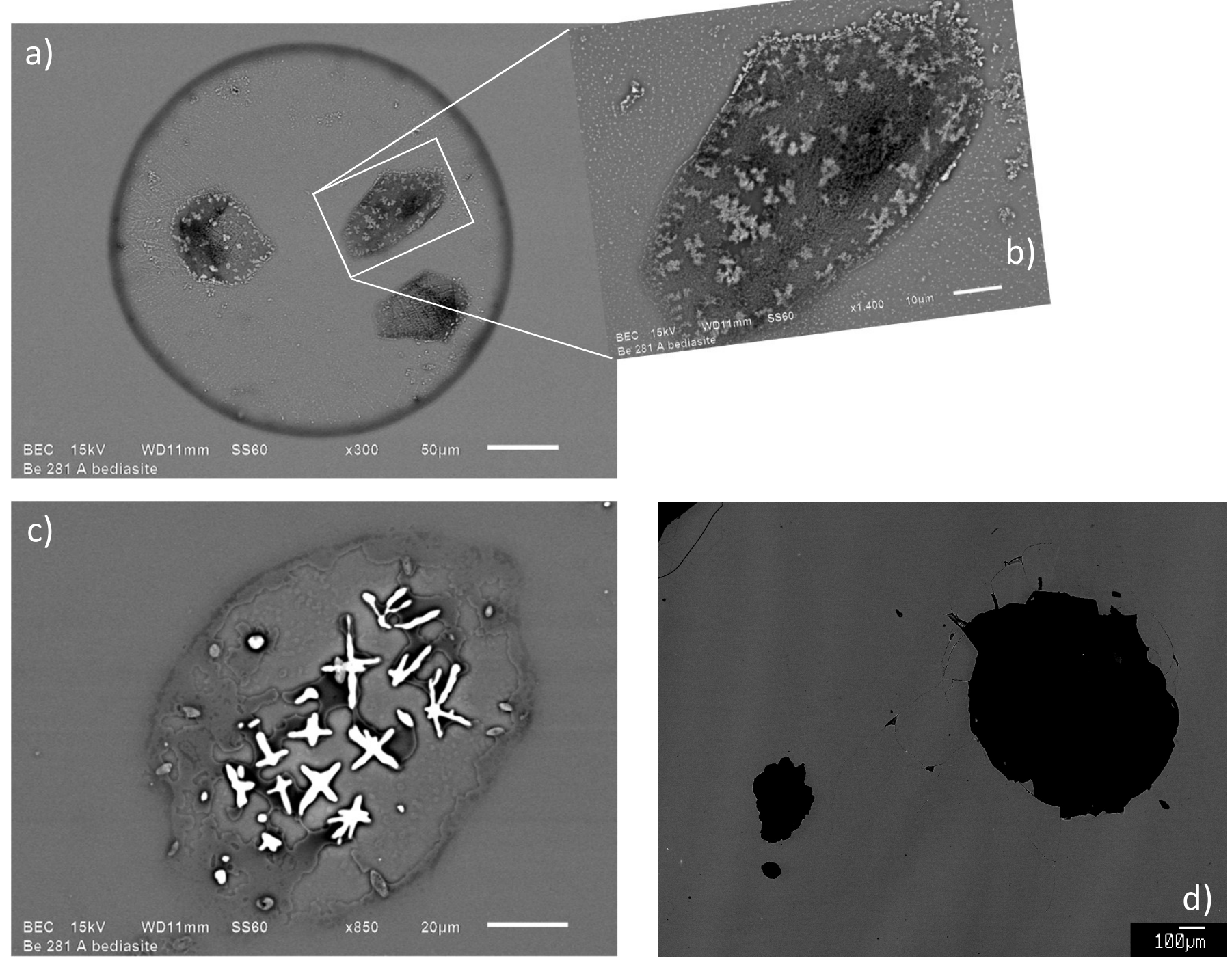

Figure 2 

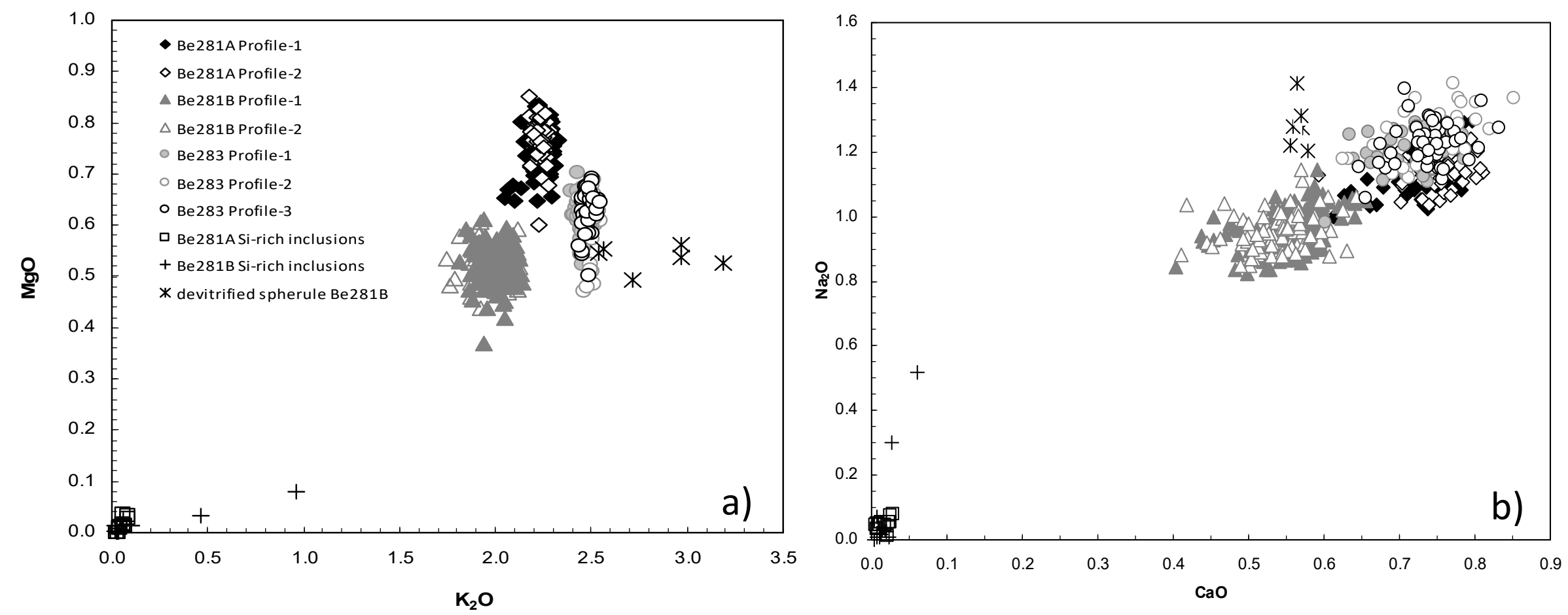

Figure 3 

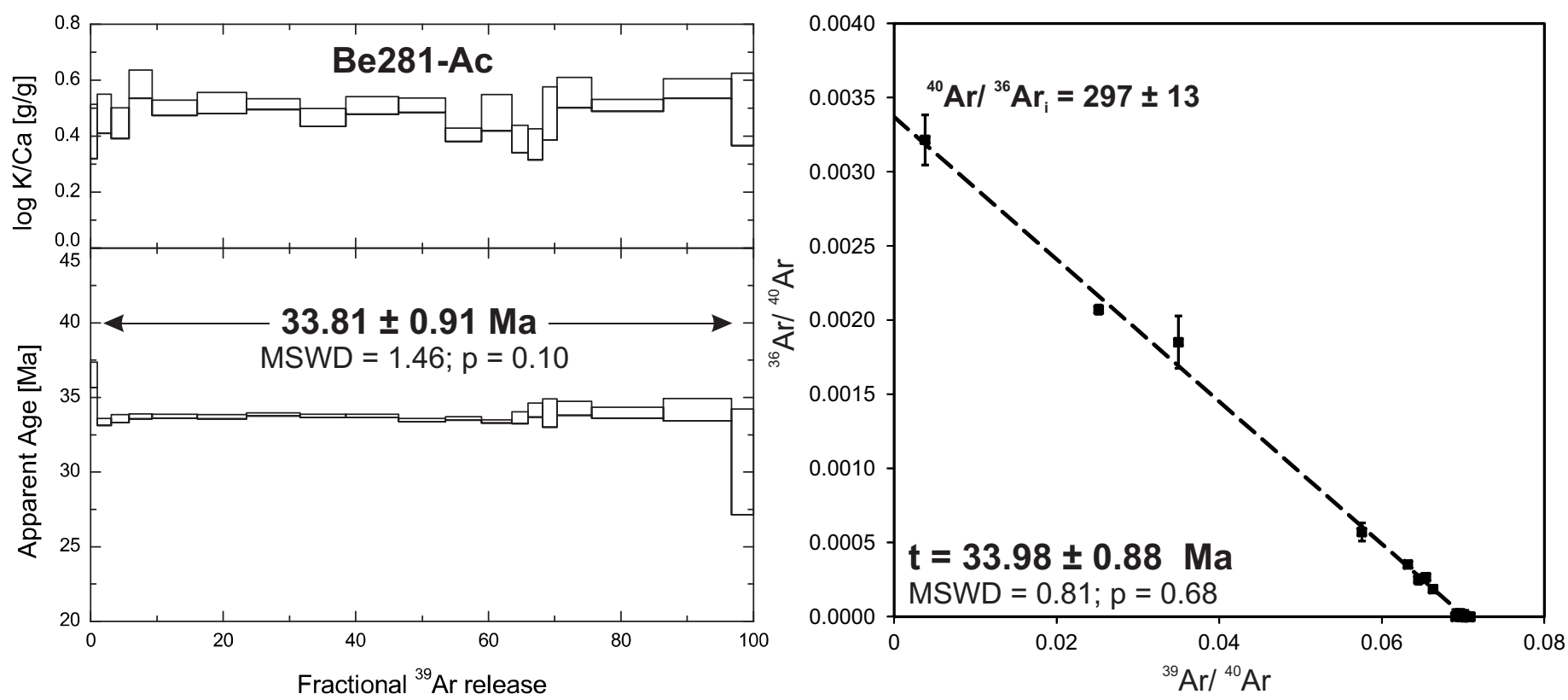

Figure 4A 

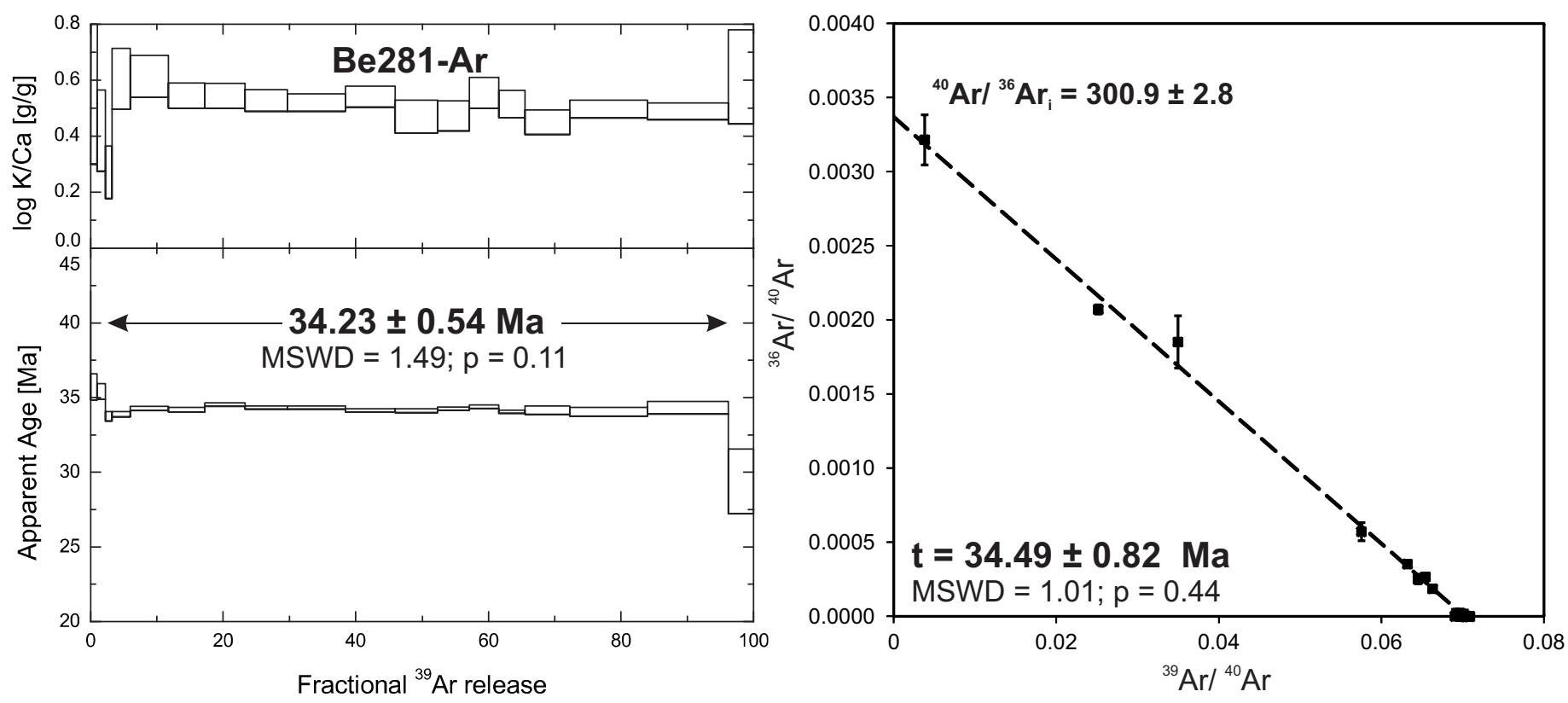

Figure 4B 

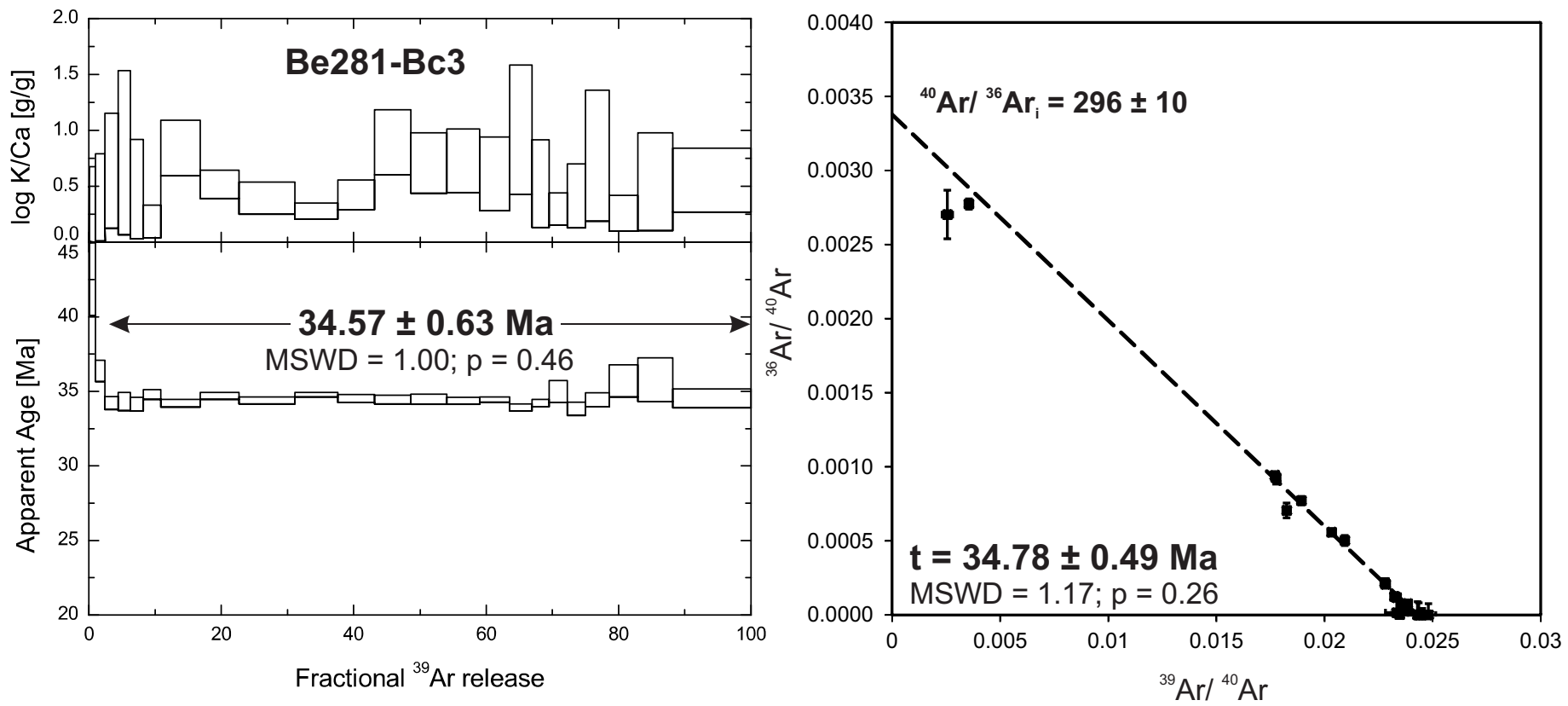

Figure 4C 

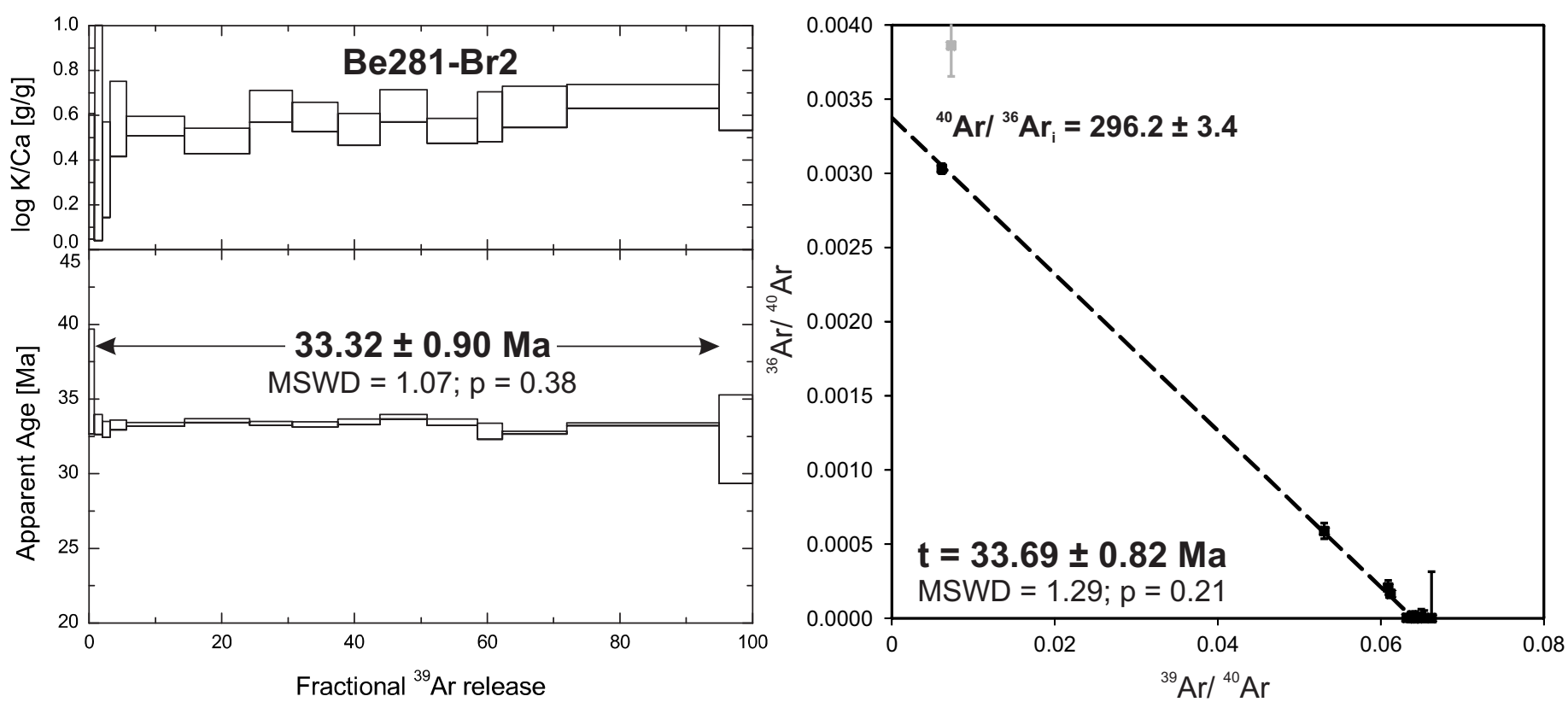

Figure 4D 

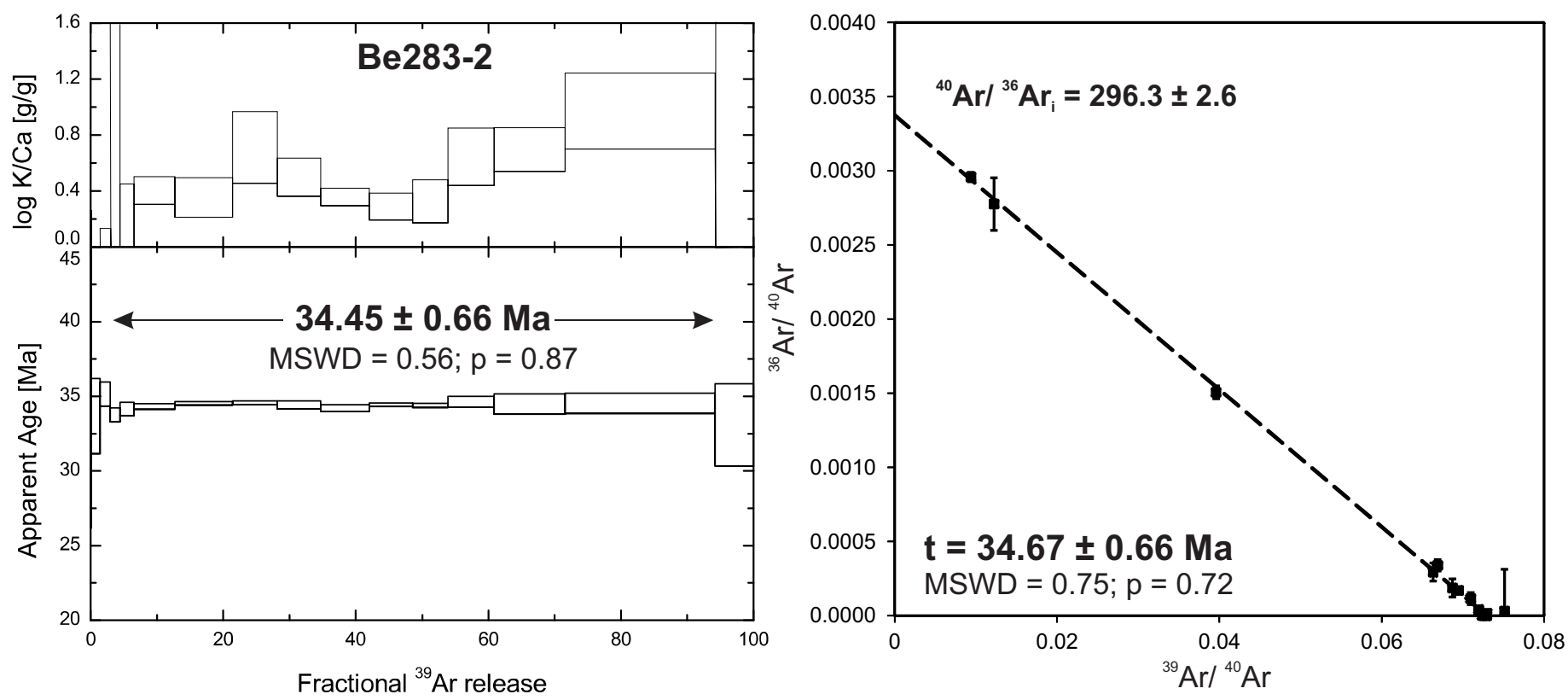

Figure 4E 

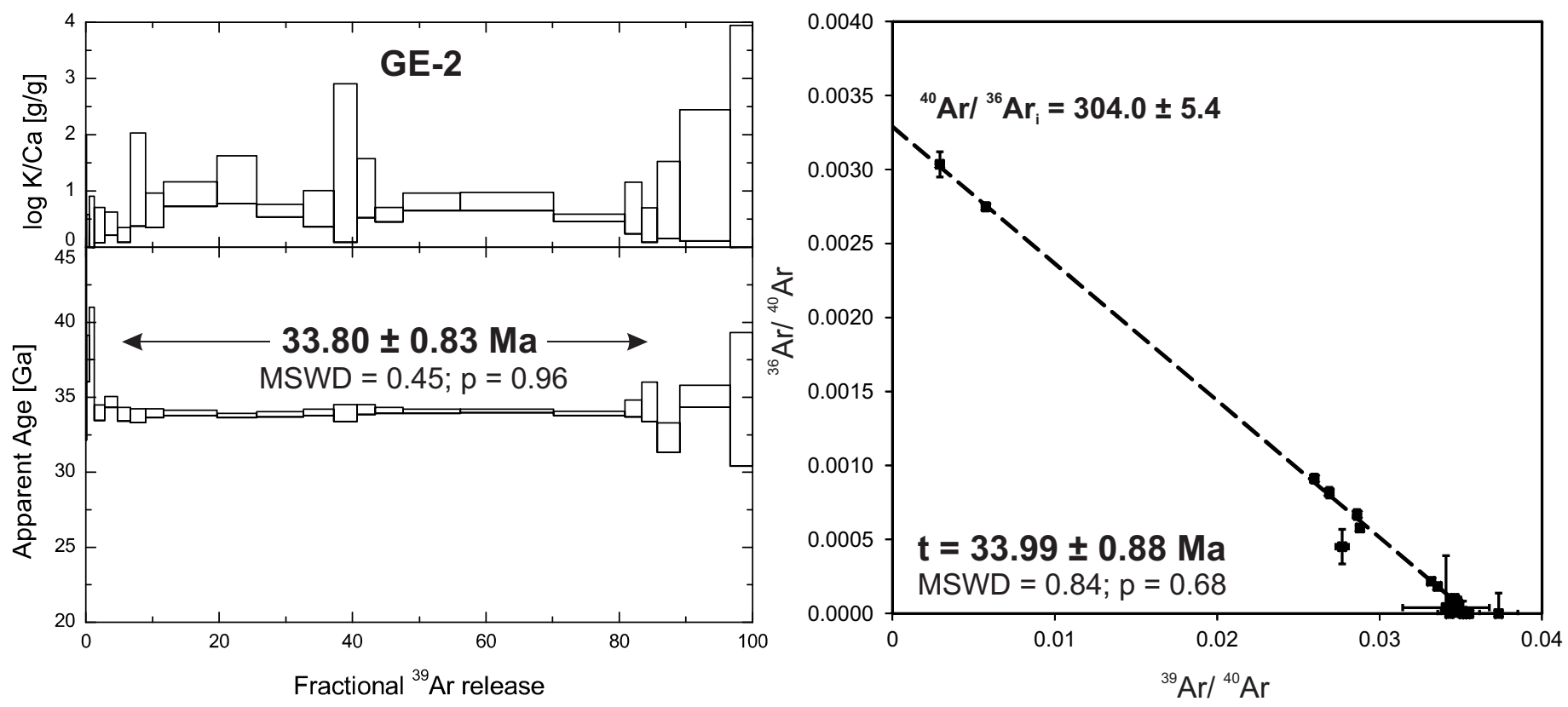

Figure 5 

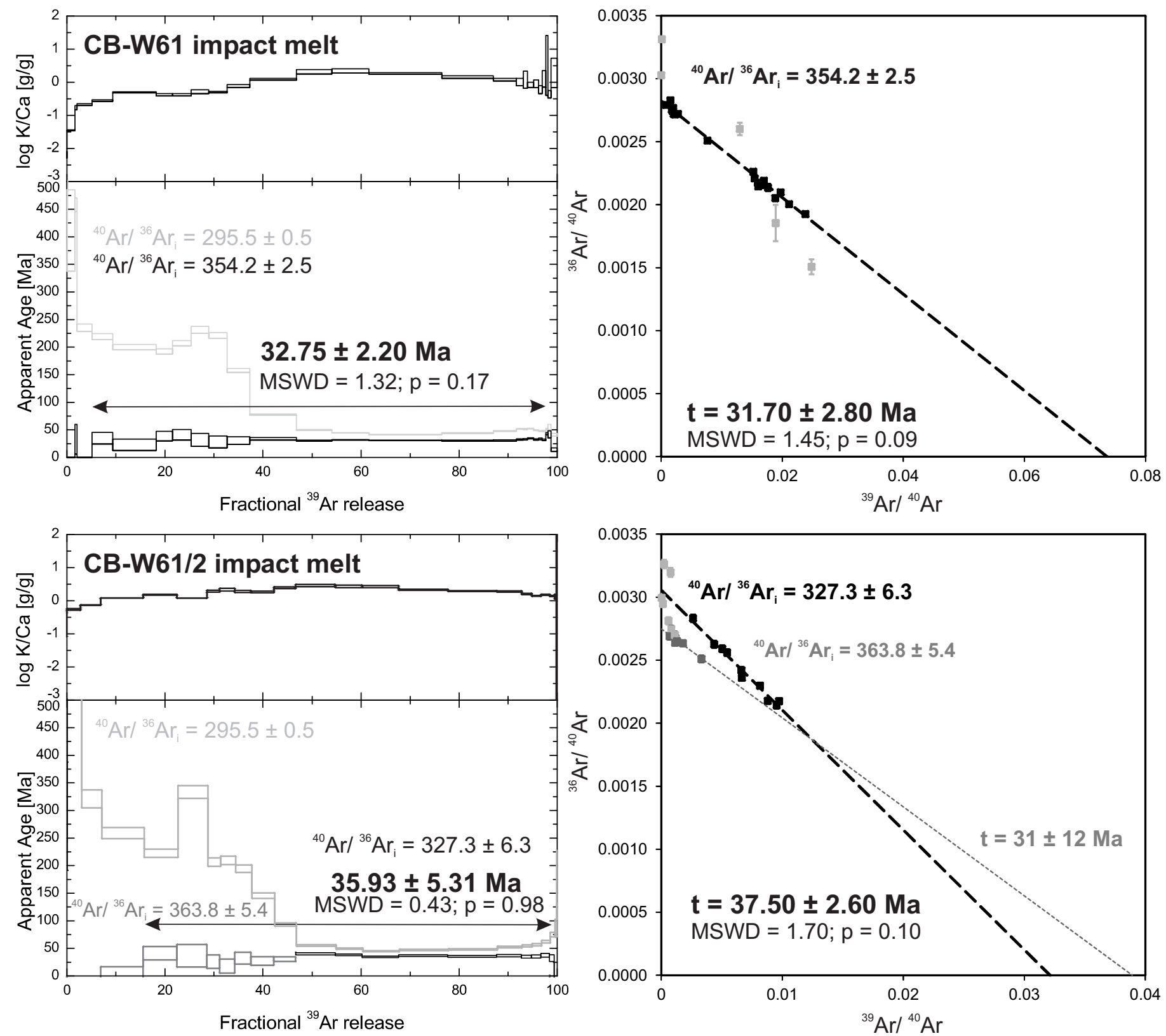

Figure 6A 

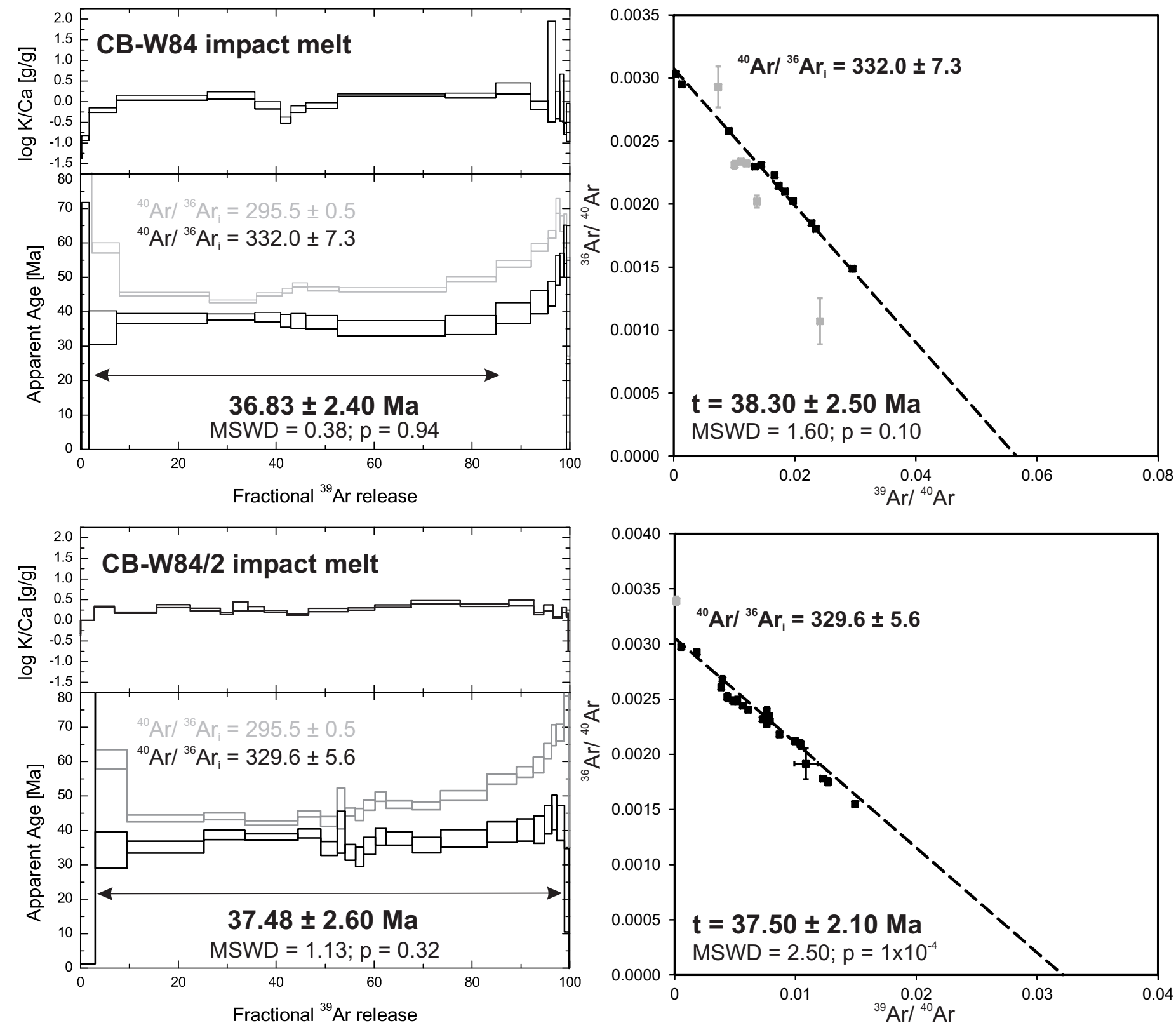

Figure 6B 


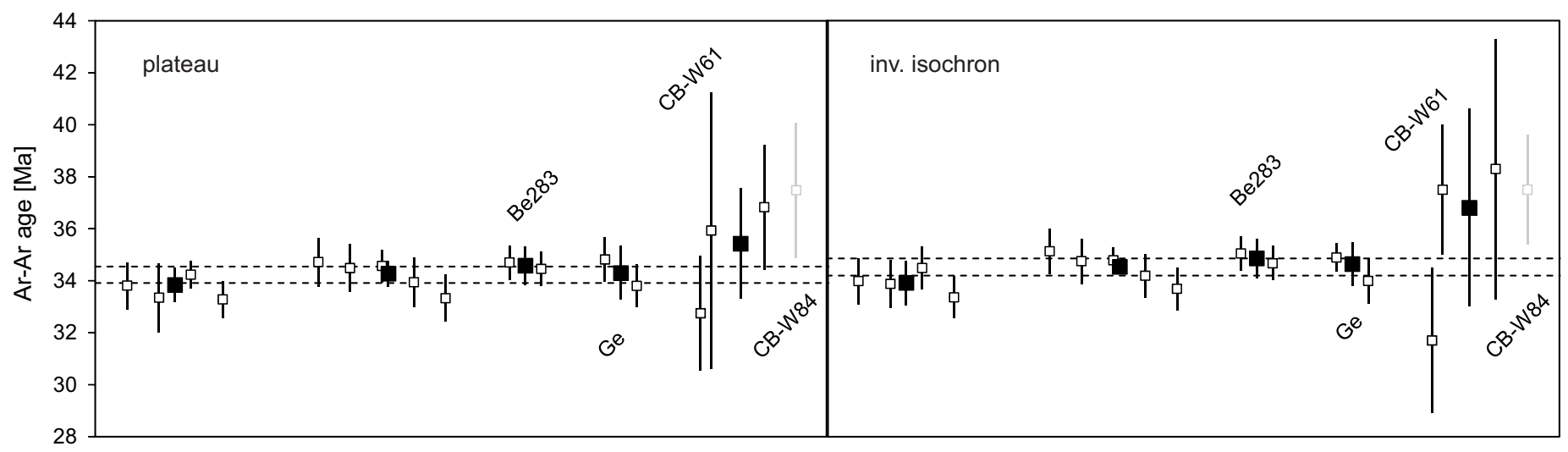

Figure 7 


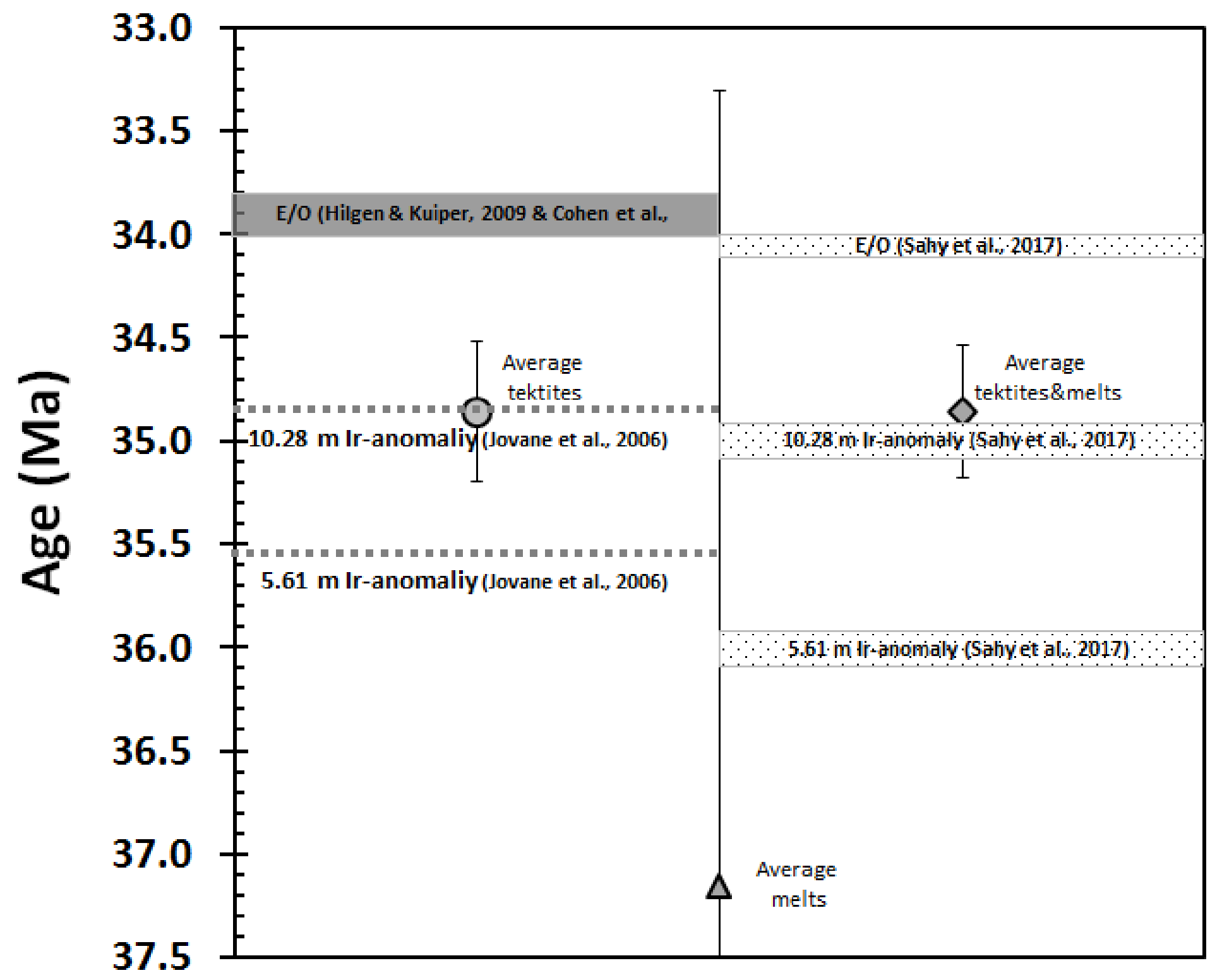

Figure 8 
Table A1 Summary of literature age data for NA Tektites and the Chesapeake Bay impact structure obtained using different analytical techniques: biostratigraphy, fission-track, ${ }^{40} \mathrm{Ar} /{ }^{39} \mathrm{Ar}$ total fusion and step heating, $\mathrm{K} / \mathrm{Ar}$ and $\mathrm{U} / \mathrm{Pb}$. Where possible, sample ages have been corrected using the Steiger and Jäger (1977) decay constants and consistent monitor ages (Schwarz and Trieloff, 2007).

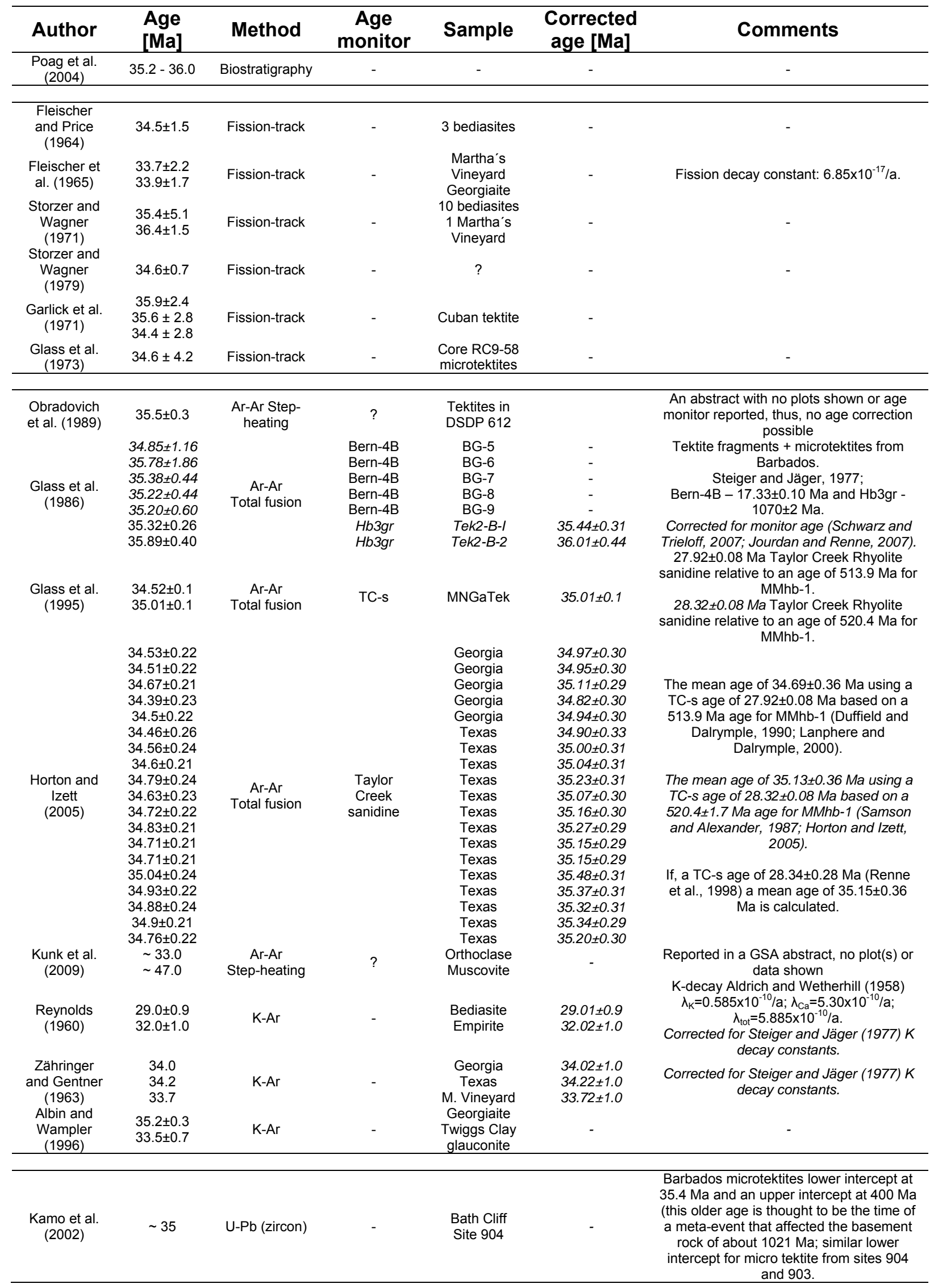




\section{REFERENCES:}

Albin, E.F., Wampler J.M., 1996. New potassium-argon ages for georgiaites and the upper Eocene Dry Branch Formation (Twiggs clay member) inferences about tektite stratigraphic occurrence. Proc. Lunar Sci. Conf. 27, 5-6.

Duffield, W.A., Dalrymple, G.B., 1990. The Taylor Creek Rhyolite of New Mexico: a rapidly emplaced field of lava domes and flows. Bulletin of Volcanology 52, 475-478.

Fleischer, R.L., Price, P.B., 1964. Fission track evidence for the simultaneous origin of tektites and other natural glasses. Geochim. Cosmochim. Acta, 28, 755-760.

Fleischer, R.I., Price, P.B., Walker R.M., 1965. On the simultaneous origin of tektites and other natural glasses. Geochim. Cosmochim. Acta, 29, 161-166.

Garlick, G.D., Naeser, C.W., O'Neil, J.R., 1971. A Cuban tektite. Geochim Cosmochim. Acta 35, 731-732.

Glass B.P., Baker R.N., Storzer D., Wagner G.A., 1973. North American microtektites from the Caribbean Sea and their fission track age. Earth Planet. Sci. Lett. 19, 184-192.

Glass, B.P., Hall, C.M., York, D., 1986. ${ }^{40} \mathrm{Ar} /{ }^{39} \mathrm{Ar}$ laser-probe dating of North-American tektite fragments from Barbados and the age of the Eocene-Oligocene boundary. Chem. Geol. 59, 191-186.

Glass, B.P., Koerbel, C., Blum, J.D., Senftle, F., Izett, G.A., Evans, B.J., Thorpe, A.N., Povenmire, H., Strange, R.L., 1995. A Muong-Nong type Georgia tektite. Geochim. Cosmochim. Acta, 59, 4071-4082.

Horton, J.W.,Jr., Izett, G.E., 2005. Crystalline-rock ejecta and shocked minerals of the Chesapeake Bay impact structure, USGS-NASA Langley Core, Hampton, Virginia, with Supplemental constraints on the age of Impact. In Horton, J. W., Jr., Powars, D. S., and Gohn, G. S., (Eds.), U.S. Geological Survey Professional Paper, E1-E30.

Jourdan, F., Renne, P., 2007. Age calibration of the Fish Canyon sanidine ${ }^{40} \mathrm{Ar} /{ }^{39} \mathrm{Ar}$ dating standard using primary $\mathrm{K}-\mathrm{Ar}$ standards. Geochim. Cosmochim. Acta 71, 387-402.

Kamo, K.T.E., Glass, B.P., Liu, S., 2002. U-Pb Study of shocked zircons from the North American microtektite layer. Proc. Lunar Sci. Conf. 33, abtst.\# 1643.

Kunk, M.J., Horton, J.W., Jr., McAleer, R.J., 2009. ${ }^{40} \mathrm{Ar} /{ }^{39} \mathrm{Ar}$ dating results from the ICDP-USGS Eyreville B core: Constraints on the thermal history of the Chesapeake Bay impact structure. Geol. Soc. of America Conf. 41, 596.

Lanphere, M.A., Dalrymple, G.B., 2000. First-principles calibration of ${ }^{38} \mathrm{Ar}$ tracers-Implications for the ages of ${ }^{40} \mathrm{Ar} /{ }^{39} \mathrm{Ar}$ fluence monitors. U.S. Geological Survey Professional Paper 1621, 10 p.

Obradovich, J.D., Snee, L.W., Izett, G.A., 1989. Is there more than one glassy impact layer in the late Eocene? Geol. Soc. of America Conf. 21, A134.

Poag, C.W., Koeberl, C., Reimold, W.U., 2004. The Chesapeake Bay impact crater-Geology and geophysics of a late Eocene submarine impact structure: New York, Springer-Verlag, 522 p., plus CD-ROM.

Reynolds, J.H., 1960. Rare gases in tektites. Geochim. et Cosmochim. Acta 20, 101-114.

Sahy, D., Condon, D. J., Hilgen, F. J., and Kuiper, K. F. (2017). Reducing disparity in radio-isotopic and astrochronology based time scales of the late Eocene and Oligocene. Paleoceanography, 32, 1018-1035.

Samson, S.D., Alexander, E.C., 1987. Calibration of the interlaboratory ${ }^{40} \mathrm{Ar} /{ }^{39} \mathrm{Ar}$ dating standard MMhb-1. Chem. Geol. 66, 2734.

Schwarz, W.H., Trieloff, M., 2007. Intercalibration of ${ }^{40} \mathrm{Ar}^{39}{ }^{39} \mathrm{Ar}$ age standards NL-25, HB3gr hornblende, GA1550, SB-3, HD-B1 biotite and BMus/2 muscovite. Chem. Geol. 242, 218-231.

Schwarz, W.H., Kossert K., Trieloff M., Hopp J., 2011. Comment on the "Joint determination of ${ }^{40} \mathrm{~K}$ decay constants and ${ }^{40} \mathrm{Ar}^{*} /^{40} \mathrm{~K}$ for the Fish Canyon sanidine standard, and improved accuracy for ${ }^{40} \mathrm{Ar} /{ }^{39} \mathrm{Ar}$ geochronology" by Paul R. Renne et al. (2010). Geochim. Cosmochim. Acta 75, 5094-5096.

Steiger, R.H., Jäger, E., 1977. Subcommission on geochronology: convention of the use of decay constants in geo- and cosmochronology. Earth Planet. Sci. Lett. 36, 359-362.

Storzer, D., Wagner, G.A., 1971. Fission track ages of North American tektites. Earth Planet. Sci. Lett. 10, 435-440. 
Storzer, D., Wagner, G.A., 1979. Fission track dating of Elgygytgyn, Popigai and Zhamanshin impact craters: No sources for Australasian or North-American tektites. Meteoritics 14, 541.

Zähringer, J., Gentner, W., 1963. Radiogenic and atmospheric argon content of tektites. Nature 199, 583. 
Table A2 Chemical composition for a profile along a bediasite obtained by electron microprobe (in wt\%).

\begin{tabular}{|c|c|c|c|c|c|c|c|c|c|c|c|}
\hline Point & $\mathrm{SiO}_{2}$ & $\mathrm{Al}_{2} \mathrm{O}_{3}$ & $\mathbf{P}_{2} \mathrm{O}_{5}$ & $\mathrm{TiO}_{2}$ & $\mathrm{FeO}$ & MnO & MgO & $\mathrm{CaO}$ & $\mathrm{Na}_{2} \mathrm{O}$ & $\mathrm{K}_{2} \mathrm{O}$ & Total \\
\hline 1 & 77.8 & 13.3 & -- & 0.73 & 3.69 & -- & 0.48 & 0.46 & 1.15 & 1.89 & 99.49 \\
\hline 2 & 77.6 & 13.3 & 0.01 & 0.72 & 3.46 & -- & 0.49 & 0.44 & 1.14 & 1.88 & 99.05 \\
\hline 3 & 79.4 & 12.56 & 0.01 & 0.72 & 3.40 & 0.03 & 0.47 & 0.40 & 1.15 & 1.86 & 100.00 \\
\hline 4 & 76.5 & 14.5 & 0.01 & 0.82 & 3.91 & 0.01 & 0.51 & 0.46 & 1.21 & 1.83 & 99.79 \\
\hline 5 & 78.0 & 13.6 & -- & 0.78 & 3.68 & 0.05 & 0.48 & 0.43 & 1.20 & 1.90 & 100.11 \\
\hline 6 & 79.0 & 13.0 & -- & 0.77 & 3.41 & 0.05 & 0.52 & 0.44 & 1.14 & 1.92 & 100.29 \\
\hline 7 & 79.1 & 13.0 & -- & 0.74 & 3.67 & 0.01 & 0.50 & 0.42 & 1.23 & 1.95 & 100.61 \\
\hline 8 & 79.5 & 12.6 & 0.06 & 0.76 & 3.44 & 0.01 & 0.51 & 0.44 & 1.15 & 2.00 & 100.43 \\
\hline 9 & 79.1 & 12.7 & -- & 0.71 & 3.46 & 0.02 & 0.51 & 0.45 & 1.17 & 1.98 & 100.18 \\
\hline 10 & 80.2 & 12.2 & 0.01 & 0.66 & 3.12 & 0.01 & 0.44 & 0.40 & 1.18 & 2.02 & 100.24 \\
\hline 11 & 79.6 & 12.7 & 0.01 & 0.71 & 3.45 & 0.01 & 0.49 & 0.40 & 1.20 & 2.01 & 100.58 \\
\hline 12 & 79.2 & 12.5 & 0.00 & 0.73 & 3.33 & 0.02 & 0.47 & 0.39 & 1.14 & 2.00 & 99.80 \\
\hline 13 & 79.2 & 12.7 & 0.01 & 0.73 & 3.24 & 0.03 & 0.46 & 0.44 & 1.18 & 1.98 & 100.00 \\
\hline 14 & 79.2 & 12.6 & -- & 0.71 & 3.41 & 0.10 & 0.47 & 0.40 & 1.19 & 1.98 & 100.01 \\
\hline 15 & 79.7 & 12.3 & 0.01 & 0.69 & 3.22 & 0.02 & 0.47 & 0.39 & 1.16 & 2.00 & 100.04 \\
\hline 16 & 80.1 & 11.8 & -- & 0.66 & 2.99 & 0.04 & 0.44 & 0.38 & 1.18 & 1.94 & 99.50 \\
\hline 17 & 80.1 & 11.9 & 0.01 & 0.67 & 3.09 & 0.05 & 0.45 & 0.42 & 1.13 & 1.96 & 99.78 \\
\hline 18 & 80.0 & 12.1 & 0.02 & 0.67 & 3.15 & 0.02 & 0.47 & 0.41 & 1.20 & 1.98 & 99.87 \\
\hline 19 & 79.5 & 12.2 & -- & 0.71 & 3.27 & 0.05 & 0.47 & 0.40 & 1.18 & 1.96 & 99.69 \\
\hline 20 & 79.8 & 12.3 & -- & 0.68 & 3.37 & 0.04 & 0.47 & 0.43 & 1.20 & 2.02 & 99.84 \\
\hline 21 & 79.3 & 12.2 & 0.02 & 0.69 & 3.19 & -- & 0.48 & 0.43 & 1.12 & 2.01 & 99.43 \\
\hline 22 & 79.4 & 12.3 & 0.05 & 0.70 & 3.31 & 0.03 & 0.49 & 0.46 & 1.17 & 2.00 & 99.94 \\
\hline 23 & 79.5 & 12.3 & 0.03 & 0.68 & 3.19 & -- & 0.48 & 0.44 & 1.20 & 2.02 & 99.78 \\
\hline 24 & 78.9 & 12.5 & -- & 0.72 & 3.29 & 0.02 & 0.49 & 0.42 & 1.18 & 2.06 & 99.52 \\
\hline 25 & 78.3 & 13.0 & 0.01 & 0.70 & 3.44 & -- & 0.52 & 0.47 & 1.16 & 1.99 & 99.57 \\
\hline 26 & 79.0 & 12.5 & 0.01 & 0.74 & 3.18 & -- & 0.47 & 0.42 & 1.15 & 2.01 & 99.46 \\
\hline 27 & 78.2 & 12.7 & 0.01 & 0.77 & 3.55 & 0.04 & 0.49 & 0.42 & 1.19 & 1.97 & 99.36 \\
\hline 28 & 77.9 & 13.1 & 0.01 & 0.77 & 3.46 & 0.08 & 0.50 & 0.47 & 1.23 & 1.97 & 99.50 \\
\hline 29 & 77.7 & 13.2 & 0.02 & 0.76 & 3.43 & 0.01 & 0.49 & 0.43 & 1.21 & 1.93 & 99.19 \\
\hline 30 & 78.3 & 12.7 & 0.04 & 0.74 & 3.40 & -- & 0.46 & 0.44 & 1.12 & 1.98 & 99.21 \\
\hline 31 & 77.9 & 12.9 & 0.02 & 0.76 & 3.48 & -- & 0.49 & 0.43 & 1.18 & 1.99 & 99.06 \\
\hline 32 & 77.5 & 13.5 & 0.02 & 0.77 & 3.57 & 0.06 & 0.51 & 0.45 & 1.20 & 1.84 & 99.34 \\
\hline 33 & 76.7 & 13.8 & -- & 0.77 & 3.65 & 0.03 & 0.51 & 0.47 & 1.24 & 1.88 & 99.07 \\
\hline 34 & 76.3 & 14.1 & -- & 0.77 & 3.79 & 0.07 & 0.53 & 0.46 & 1.25 & 1.90 & 99.14 \\
\hline 35 & 78.0 & 13.1 & 0.01 & 0.73 & 3.51 & 0.02 & 0.47 & 0.42 & 1.16 & 1.91 & 99.32 \\
\hline 36 & 78.7 & 12.5 & 0.02 & 0.68 & 3.33 & -- & 0.43 & 0.41 & 1.13 & 1.89 & 99.07 \\
\hline 37 & 78.9 & 12.6 & -- & 0.71 & 3.25 & 0.06 & 0.47 & 0.41 & 1.16 & 1.90 & 99.45 \\
\hline 38 & 77.9 & 13.1 & 0.02 & 0.76 & 3.51 & 0.03 & 0.48 & 0.47 & 1.10 & 1.90 & 99.29 \\
\hline 39 & 78.5 & 12.8 & 0.02 & 0.73 & 3.36 & 0.06 & 0.46 & 0.39 & 1.14 & 1.81 & 99.27 \\
\hline 40 & 79.6 & 12.0 & -- & 0.68 & 3.14 & -- & 0.42 & 0.39 & 1.15 & 1.89 & 99.24 \\
\hline 41 & 79.6 & 12.1 & -- & 0.69 & 3.09 & 0.06 & 0.42 & 0.39 & 1.09 & 1.89 & 99.33 \\
\hline 42 & 78.5 & 12.7 & 0.02 & 0.76 & 3.32 & 0.03 & 0.47 & 0.42 & 1.14 & 1.90 & 99.25 \\
\hline Average & 78.7 & 12.7 & 0.01 & 0.72 & 3.39 & 0.03 & 0.48 & 0.43 & 1.17 & 1.94 & 99.64 \\
\hline $1 \sigma$ & 1.0 & 0.6 & 0.01 & 0.04 & 0.20 & 0.03 & 0.03 & 0.03 & 0.04 & 0.06 & 0.43 \\
\hline
\end{tabular}


Table A3 Chemical composition for a profile along a georgiaite obtained by electron microprobe (in wt\%).

\begin{tabular}{|c|c|c|c|c|c|c|c|c|c|c|c|}
\hline Point & $\mathrm{SiO}_{2}$ & $\mathrm{Al}_{2} \mathrm{O}_{3}$ & $\mathrm{P}_{2} \mathrm{O}_{5}$ & $\mathrm{TiO}_{2}$ & $\mathrm{FeO}$ & & $\mathrm{MgO}$ & $\mathrm{CaO}$ & $\mathrm{Na}_{2} \mathrm{O}$ & $\mathrm{K}_{2} \mathrm{O}$ & \\
\hline 1 & 79.7 & 12.1 & 0.06 & 0.60 & 3.36 & & 0.73 & 0.52 & 1.00 & 2.31 & 100.47 \\
\hline 2 & & & & 50 & & & & & & 30 & \\
\hline 3 & & 2.3 & -- & 0.60 & & & & & & 2.32 & \\
\hline 4 & & 1.7 & -- & 55 & & & & & & 2.33 & \\
\hline 5 & & 11.7 & & 0.57 & & & & & & .35 & \\
\hline 6 & & 12.1 & .02 & .59 & .37 & & 0.70 & .50 & & 2.33 & \\
\hline 7 & 3.9 & 12.5 & 0.02 & 0.59 & 3.37 & .06 & 0.72 & .55 & .08 & 2.28 & \\
\hline 8 & & 12.3 & -- & 0.62 & .46 & 6 & 0.76 & 0.50 & 04 & 2.30 & \\
\hline 9 & & 12.7 & 0.05 & 0.58 & & & 0.75 & & & 2.34 & \\
\hline 10 & .4 & 11.8 & 01 & 0.57 & 3.22 & & 0.67 & 51 & 03 & 2.29 & \\
\hline & & 12 & & 60 & & & & & & & \\
\hline 12 & .9 & 12.4 & 03 & 0.61 & 3.41 & & 0.72 & 0.52 & 98 & 2.29 & \\
\hline & & 2.4 & & .56 & 5 & & 0.77 & & & 2.26 & \\
\hline & & & & .62 & & & & & & & \\
\hline & & 12.4 & 02 & .58 & 1 & & 0.7 & & & 2.39 & \\
\hline & & & & 51 & & & & & & & \\
\hline 1 & & 12.3 & 01 & 0.57 & 3.46 & & 0.7 & 53 & 1.00 & 2.26 & \\
\hline & & 1 & & & & & & & & & \\
\hline & & & & 0.61 & & & & & & 2.29 & \\
\hline & & 12.4 & & .61 & 7 & & & & & 2.27 & \\
\hline & & & & 0.60 & 3.4 & & & & & 2.38 & \\
\hline & & 12.4 & & 0.62 & 3.4 & & 0.7 & & & 2.29 & \\
\hline & & & & & & & & & & & \\
\hline 2 & & 12.3 & 01 & 0.58 & 0 & & 0.7 & & & 2.30 & \\
\hline & & 12. & & .56 & 3 & & 7 & & & 2.27 & \\
\hline & & & & .55 & & & & & & 2.35 & \\
\hline & & 11.9 & 0.04 & 0.59 & 3.34 & & 0.70 & 50 & 2 & 2.33 & \\
\hline & & & -- & & & & & & & 2.31 & \\
\hline 2 & & 11.9 & 0.04 & 0.55 & 3.26 & 0.11 & 0.68 & 0.49 & 1.00 & 2.26 & \\
\hline & & & -- & 0.58 & & & & & & 2.37 & \\
\hline 3 & & & & 0.55 & 3.1 & & 0.72 & 0.51 & & 2.32 & \\
\hline & & & 0.03 & & & & & & & 2.27 & \\
\hline & & & & 61 & 6 & & & & & 2.33 & \\
\hline & & 11.9 & & 0.54 & 3.29 & 0.04 & 0.68 & 0.51 & .02 & 2.29 & \\
\hline & & & 0.03 & 0.56 & & 0. & 0.67 & & & 2.34 & \\
\hline 35 & 79.2 & & -- & 0.54 & 3.30 & 0.05 & 0.71 & 0.52 & 0.98 & 2.27 & \\
\hline 37 & & & -- & & 3.23 & & 0.69 & & & 2.32 & \\
\hline 38 & & & 0.03 & 0.55 & 3.27 & & 0.69 & 0.49 & 1.00 & 2.30 & 100.28 \\
\hline 39 & & & & 0.56 & 3.27 & & & & & 2.33 & \\
\hline 40 & 80.3 & & 0.04 & 0.53 & 3.16 & & 0.68 & 0.48 & 0.99 & 2.32 & 100.05 \\
\hline & 79.6 & 12.1 & 0.02 & 0.58 & 3.34 & & 0.71 & 0.52 & 1.01 & 2.31 & 100.23 \\
\hline $1 \sigma$ & 0.5 & 0.3 & 0.02 & 0.03 & 0.11 & 0.04 & 0.03 & 0.02 & 0.03 & 0.04 & 0.40 \\
\hline
\end{tabular}


Appendix tables A4-A20 display measured argon isotopes corrected for mass discrimination, sensitivity, system blanks, decay and relative neutron doses. All isotopes are also corrected for interfering isotopes produced on $\mathrm{K}$ and Ca during irradiation. Remaining argon isotopes are given in ccSTP/g and have the following composition:

$36 \mathrm{Ar}=36 \mathrm{Aratm}$

$37 \mathrm{Ar}=37 \mathrm{ArCa}$

$38 \mathrm{Ar}=38 \mathrm{Aratm}+38 \mathrm{ArCl}$

$39 \mathrm{Ar}=39 \mathrm{ArK}$

$40 \mathrm{Ar}=40 \mathrm{Arrad}+40 \mathrm{Aratm}+40 \mathrm{Arexc}$ atm: terrestrial atmospheric argon

Ca: $\quad$ argon derived from $\mathrm{Ca}$

$\mathrm{Cl}: \quad$ argon derived from $\mathrm{Cl}$

$\mathrm{K}: \quad$ argon derived from $\mathrm{K}$

exc: excess argon

Apparent ages reported in the tables below were calculated by subtracting trapped 40Ar from total 40Ar. For tektite samples that yielded inverse isochron 40Ar/36Ar intercepts indistinguishable from air, we used the atmospheric 40Ar/36Ar ratio of 295.5 \pm 0.5 for each temperature extraction. For Chesapeake Bay Crater impact melt samples, we used the 40Ar/36Ar intercepts from inverse isochrones as listed in Table 1 and listed in table headers A17-A20.

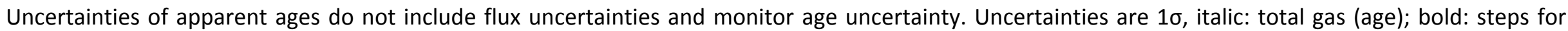
plateau calculation, calculated with Steiger and Jäger (1977) recommended values (for age and atmospheric corrections). 


\begin{tabular}{|l|c|c|c|c|c|c|c|c|c|c|c|c|}
\hline $\begin{array}{l}\text { Temp. } \\
\left({ }^{\circ} \mathbf{C}\right)\end{array}$ & ${ }^{40} \mathbf{A r}$ & $\mathbf{\pm}^{40} \mathbf{A r}$ & ${ }^{39} \mathbf{A r}$ & $\mathbf{\pm}^{39} \mathbf{A r}$ & ${ }^{38} \mathbf{A r}$ & $\pm^{\mathbf{3 8}} \mathbf{A r}$ & ${ }^{37} \mathbf{A r}$ & $\pm^{37} \mathbf{A r}$ & ${ }^{36} \mathbf{A r}$ & $\pm^{36} \mathbf{A r}$ & $\begin{array}{c}\text { Age } \\
(\mathbf{M a})\end{array}$ & $\begin{array}{c} \pm \text { Age } \\
(\mathbf{M a})\end{array}$ \\
\hline 600 & 640 & 10 & 2 & 1 & 0.57 & 0.07 & 5 & 5 & 2.06 & 0.11 & 31.01 & 30.86 \\
\hline 800 & 7670 & 40 & 193 & 1 & 3.43 & 0.18 & 38 & 8 & 15.88 & 0.25 & 36.52 & 0.86 \\
\hline 900 & 6670 & 40 & 436 & 3 & 0.73 & 0.18 & 74 & 12 & 1.77 & 0.11 & $\mathbf{3 3 . 3 6}$ & $\mathbf{0 . 2 3}$ \\
\hline 960 & 8470 & 160 & 536 & 10 & 1.39 & 0.22 & 98 & 12 & 2.98 & 0.19 & $\mathbf{3 3 . 5 7}$ & $\mathbf{0 . 2 7}$ \\
\hline 1040 & 10810 & 200 & 717 & 13 & 0.94 & 0.26 & 95 & 11 & 2.01 & 0.15 & $\mathbf{3 3 . 7 4}$ & $\mathbf{0 . 1 8}$ \\
\hline 1100 & 19860 & 360 & 1384 & 26 & 1.83 & 0.47 & 223 & 14 & 0.41 & 0.10 & $\mathbf{3 3 . 7 5}$ & $\mathbf{0 . 1 3}$ \\
\hline 1140 & 21590 & 400 & 1517 & 28 & 2.11 & 0.53 & 234 & 20 & - & - & $\mathbf{3 3 . 7 0}$ & $\mathbf{0 . 1 2}$ \\
\hline 1180 & 23450 & 430 & 1639 & 30 & 2.12 & 0.56 & 256 & 11 & - & - & $\mathbf{3 3 . 8 6}$ & $\mathbf{0 . 1 1}$ \\
\hline 1220 & 20050 & 370 & 1406 & 26 & 1.34 & 0.48 & 245 & 18 & - & - & $\mathbf{3 3 . 7 6}$ & $\mathbf{0 . 1 1}$ \\
\hline 1260 & 22900 & 430 & 1606 & 31 & 1.59 & 0.53 & 253 & 18 & - & - & $\mathbf{3 3 . 7 6}$ & $\mathbf{0 . 1 1}$ \\
\hline 1300 & 20520 & 400 & 1451 & 29 & 1.64 & 0.5 & 228 & 13 & - & - & $\mathbf{3 3 . 4 9}$ & $\mathbf{0 . 1 1}$ \\
\hline 1320 & 15560 & 30 & 1097 & 4 & 0.79 & 0.38 & 220 & 11 & - & - & $\mathbf{3 3 . 5 9}$ & $\mathbf{0 . 1 3}$ \\
\hline 1350 & 13240 & 30 & 939 & 3 & 1.02 & 0.37 & 157 & 23 & - & - & $\mathbf{3 3 . 4 0}$ & $\mathbf{0 . 1 1}$ \\
\hline 1380 & 7150 & 20 & 503 & 2 & 0.22 & 0.22 & 104 & 11 & 0.03 & 0.03 & $\mathbf{3 3 . 6 4}$ & $\mathbf{0 . 3 9}$ \\
\hline 1420 & 6390 & 10 & 442 & 2 & 0.44 & 0.18 & 96 & 12 & 0.02 & 0.02 & $\mathbf{3 4 . 1 5}$ & $\mathbf{0 . 4 7}$ \\
\hline 1460 & 6250 & 20 & 435 & 2 & 0.29 & 0.22 & 73 & 16 & 0.00 & 0.00 & $\mathbf{3 4 . 0 0}$ & $\mathbf{0 . 1 4}$ \\
\hline 1540 & 15340 & 40 & 1059 & 3 & 0.88 & 0.39 & 150 & 19 & 0.02 & 0.02 & $\mathbf{3 4 . 2 7}$ & $\mathbf{0 . 4 8}$ \\
\hline 1600 & 34250 & 70 & 2209 & 6 & 3.73 & 0.81 & 348 & 16 & 8.60 & 1.10 & $\mathbf{3 3 . 9 8}$ & $\mathbf{0 . 3 6}$ \\
\hline 1700 & 36260 & 90 & 2087 & 7 & 5.31 & 0.83 & 286 & 22 & 20.70 & 2.20 & $\mathbf{3 4 . 1 9}$ & $\mathbf{0 . 7 4}$ \\
\hline 1750 & 19150 & 80 & 670 & 4 & 5.74 & 0.76 & 109 & 32 & 35.50 & 3.40 & 30.69 & 3.52 \\
\hline Total & $\mathbf{3 1 6 2 0 0}$ & 1000 & $\mathbf{2 0 3 2 8}$ & $\mathbf{7 3}$ & $\mathbf{3 6 . 1}$ & $\mathbf{2 . 1}$ & $\mathbf{3 2 9 3}$ & $\mathbf{7 4}$ & $\mathbf{8 9 . 9 0}$ & $\mathbf{4 . 2 0}$ & $\mathbf{3 3 . 7 3}$ & $\mathbf{0 . 1 5}$ \\
\hline
\end{tabular}


Table A5 ${ }^{40} \mathrm{Ar} /{ }^{39} \mathrm{Ar}$ step heating results for core fragment Be281-Ac2 $\times 10^{-11} \mathrm{ccSTP} / \mathrm{g}$. Uncertainties at $1 \sigma$ level. $\quad \mathrm{J}=0,001318 \pm 0,000017$

\begin{tabular}{|c|c|c|c|c|c|c|c|c|c|c|c|c|}
\hline $\begin{array}{l}\text { Temp. } \\
\left({ }^{\circ} \mathrm{C}\right)\end{array}$ & ${ }^{40} \mathrm{Ar}$ & $\pm^{40} \mathrm{Ar}$ & ${ }^{39} \mathrm{Ar}$ & $\pm^{39} \mathrm{Ar}$ & ${ }^{38} \mathrm{Ar}$ & $\pm^{38} \mathrm{Ar}$ & ${ }^{37} \mathrm{Ar}$ & $\pm^{37} \mathrm{Ar}$ & ${ }^{36} \mathrm{Ar}$ & $\pm^{36} \mathrm{Ar}$ & $\begin{array}{c}\text { Age } \\
\text { (Ma) }\end{array}$ & $\begin{array}{l} \pm \text { Age } \\
\text { (Ma) }\end{array}$ \\
\hline 400 & 3180 & 40 & 1 & 1 & 2.0 & 0.2 & 7 & 5 & 11.5 & 0.4 & 0.00 & 0.00 \\
\hline 500 & 2060 & 30 & 14 & 1 & 1.4 & 0.2 & 1 & 1 & 6.5 & 0.3 & 23.23 & 14.43 \\
\hline 600 & 2440 & 40 & 74 & 1 & 1.3 & 0.3 & 11 & 5 & 5.0 & 0.3 & 30.12 & 2.63 \\
\hline 700 & 30330 & 390 & 64 & 1 & 19.6 & 0.5 & 26 & 3 & 98.2 & 1.5 & 47.42 & 9.04 \\
\hline 800 & 5820 & 90 & 243 & 4 & 2.6 & 0.4 & 59 & 8 & 7.9 & 0.4 & 33.58 & 1.01 \\
\hline 900 & 3800 & 20 & 206 & 2 & 0.7 & 0.4 & 30 & 6 & 2.8 & 0.4 & 33.89 & 1.17 \\
\hline 1000 & 12690 & 60 & 635 & 5 & 2.6 & 0.6 & 98 & 10 & 11.1 & 0.7 & 34.56 & 0.75 \\
\hline 1100 & 38620 & 150 & 2617 & 12 & 3.6 & 1.0 & 385 & 11 & 2.3 & 0.7 & 33.88 & 0.21 \\
\hline 1150 & 29950 & 130 & 2037 & 11 & 1.6 & 0.8 & 278 & 9 & 2.2 & 0.7 & 33.61 & 0.26 \\
\hline 1170 & 19650 & 220 & 1382 & 16 & 1.3 & 0.7 & 208 & 9 & - & - & 33.22 & 0.12 \\
\hline 1190 & 17170 & 200 & 1211 & 14 & 1.1 & 0.6 & 174 & 9 & - & - & 33.13 & 0.55 \\
\hline 1240 & 26830 & 320 & 1664 & 20 & 3.6 & 0.8 & 235 & 10 & 10.0 & 1.1 & 33.56 & 0.43 \\
\hline 1300 & 28430 & 390 & 1519 & 21 & 6.0 & 0.9 & 231 & 10 & 23.1 & 1.5 & 33.27 & 0.62 \\
\hline 1350 & 42110 & 560 & 1195 & 16 & 18.0 & 0.9 & 170 & 8 & 85.7 & 2.4 & 32.85 & 1.22 \\
\hline 1400 & 43510 & 670 & 1118 & 18 & 17.2 & 0.9 & 157 & 10 & 96.3 & 3.5 & 31.46 & 1.90 \\
\hline 1500 & 81400 & 1300 & 806 & 13 & 45.2 & 1.4 & 106 & 11 & 249.2 & 6.5 & 22.55 & 4.44 \\
\hline 1600 & 130530 & 680 & 1444 & 9 & 70.0 & 2.1 & 158 & 18 & 378.9 & 8.9 & 30.07 & 4.11 \\
\hline Total & 518500 & 1800 & 16230 & 50 & 197.6 & 3.6 & 2334 & 38 & 990.8 & 12.1 & 32.55 & 0.47 \\
\hline
\end{tabular}




\begin{tabular}{|c|c|c|c|c|c|c|c|c|c|c|c|c|}
\hline $\begin{array}{l}\text { Temp. } \\
\left({ }^{\circ} \mathrm{C}\right)\end{array}$ & ${ }^{40} \mathrm{Ar}$ & $\pm^{40} \mathrm{Ar}$ & ${ }^{39} \mathrm{Ar}$ & $\pm^{39} \mathrm{Ar}$ & ${ }^{38} \mathrm{Ar}$ & $\pm^{38} \mathrm{Ar}$ & ${ }^{37} \mathrm{Ar}$ & $\pm^{37} \mathrm{Ar}$ & ${ }^{36} \mathrm{Ar}$ & $\pm^{36} \mathrm{Ar}$ & $\begin{array}{c}\text { Age } \\
\text { (Ma) }\end{array}$ & $\begin{array}{l}\text { 土Age } \\
\text { (Ma) }\end{array}$ \\
\hline 600 & 780 & 10 & 3 & 1 & 0.56 & 0.06 & 2 & 2 & 2.32 & 0.09 & 60.50 & 18.36 \\
\hline 800 & 10690 & 80 & 189 & 2 & 5.20 & 0.18 & 15 & 15 & 26.33 & 0.31 & 35.72 & 0.88 \\
\hline 900 & 5600 & 40 & 226 & 2 & 1.77 & 0.12 & 44 & 15 & 7.25 & 0.18 & 35.40 & 0.53 \\
\hline 960 & 3480 & 30 & 191 & 2 & 0.54 & 0.11 & 52 & 11 & 2.35 & 0.07 & 33.76 & 0.31 \\
\hline 1040 & 8360 & 70 & 526 & 4 & 0.96 & 0.20 & 67 & 17 & 2.27 & 0.10 & 33.89 & 0.17 \\
\hline 1100 & 16390 & 130 & 1087 & 9 & 1.04 & 0.39 & 135 & 23 & 1.01 & 0.13 & 34.28 & 0.14 \\
\hline 1140 & 15710 & 30 & 1033 & 4 & 1.31 & 0.38 & 150 & 15 & 1.58 & 0.10 & 34.19 & 0.16 \\
\hline 1180 & 17030 & 30 & 1143 & 4 & 1.00 & 0.39 & 167 & 16 & - & - & 34.53 & 0.12 \\
\hline 1220 & 17850 & 30 & 1204 & 4 & 0.92 & 0.43 & 182 & 16 & - & - & 34.33 & 0.11 \\
\hline 1260 & 24520 & 50 & 1654 & 5 & 1.05 & 0.55 & 255 & 18 & - & - & 34.33 & 0.10 \\
\hline 1300 & 20930 & 40 & 1421 & 4 & 1.50 & 0.48 & 209 & 18 & - & - & 34.13 & 0.11 \\
\hline 1350 & 17750 & 30 & 1205 & 4 & 1.05 & 0.42 & 208 & 27 & - & - & 34.13 & 0.12 \\
\hline 1380 & 13290 & 30 & 898 & 3 & 0.74 & 0.32 & 154 & 19 & - & - & 34.28 & 0.11 \\
\hline 1420 & 12430 & 30 & 838 & 3 & 0.69 & 0.31 & 119 & 15 & - & - & 34.38 & 0.11 \\
\hline 1500 & 10920 & 20 & 743 & 2 & 0.80 & 0.31 & 116 & 13 & - & - & 34.06 & 0.11 \\
\hline 1560 & 19230 & 40 & 1282 & 4 & 1.35 & 0.49 & 232 & 23 & 1.09 & 0.49 & 34.17 & 0.28 \\
\hline 1620 & 33510 & 60 & 2214 & 6 & 2.04 & 0.78 & 360 & 25 & 3.28 & 0.88 & 34.05 & 0.29 \\
\hline 1700 & 34090 & 90 & 2300 & 7 & 1.58 & 0.87 & 381 & 25 & 0.03 & 0.03 & 34.33 & 0.41 \\
\hline 1750 & 9090 & 70 & 717 & 6 & 0.31 & 0.31 & 90 & 35 & 0.01 & 0.01 & 29.39 & 2.18 \\
\hline Total & 291640 & 240 & 18874 & 19 & 24.40 & 1.90 & 2937 & 85 & 47.50 & 1.10 & 34.08 & 0.11 \\
\hline
\end{tabular}




\begin{tabular}{|c|c|c|c|c|c|c|c|c|c|c|c|c|}
\hline $\begin{array}{l}\text { Temp. } \\
\left({ }^{\circ} \mathrm{C}\right)\end{array}$ & ${ }^{40} \mathrm{Ar}$ & $\pm^{40} \mathrm{Ar}$ & ${ }^{39} \mathrm{Ar}$ & $\pm^{39} \mathrm{Ar}$ & ${ }^{38} \mathrm{Ar}$ & $\pm^{38} \mathrm{Ar}$ & ${ }^{37} \mathrm{Ar}$ & $\pm^{37} \mathrm{Ar}$ & ${ }^{36} \mathrm{Ar}$ & $\pm^{36} \mathrm{Ar}$ & $\begin{array}{c}\text { Age } \\
\text { (Ma) }\end{array}$ & $\begin{array}{l} \pm \text { Age } \\
\text { (Ma) }\end{array}$ \\
\hline 600 & 1890 & 30 & 15 & 1 & 1.00 & 0.10 & 0.1 & 0.1 & 5.44 & 0.21 & 43.96 & 8.66 \\
\hline 800 & 27280 & 360 & 259 & 4 & 15.40 & 0.50 & 47.3 & 6.2 & 78.50 & 1.30 & 36.54 & 2.14 \\
\hline 900 & 3710 & 50 & 205 & 3 & 0.50 & 0.20 & 31.0 & 4.0 & 3.09 & 0.27 & 31.80 & 0.90 \\
\hline 1000 & 6760 & 90 & 392 & 5 & 1.00 & 0.30 & 58.5 & 4.8 & 4.12 & 0.18 & 32.92 & 0.33 \\
\hline 1050 & 15240 & 180 & 1031 & 13 & 1.40 & 0.30 & 168.9 & 6.3 & 1.74 & 0.24 & 33.20 & 0.20 \\
\hline 1090 & 22970 & 270 & 1516 & 18 & 2.00 & 0.70 & 227.3 & 6.5 & 4.52 & 0.28 & 33.17 & 0.17 \\
\hline 1120 & 12160 & 150 & 798 & 10 & 1.30 & 0.40 & 115.2 & 7.2 & 2.81 & 0.21 & 33.00 & 0.22 \\
\hline 1140 & 12880 & 330 & 851 & 22 & 1.20 & 0.50 & 118.5 & 7.3 & 2.65 & 0.22 & 33.03 & 0.22 \\
\hline 1160 & 15590 & 390 & 1035 & 26 & 1.20 & 0.40 & 147.6 & 6.4 & 2.70 & 0.24 & 33.23 & 0.20 \\
\hline 1180 & 13320 & 350 & 895 & 24 & 1.40 & 0.40 & 144.7 & 6.2 & 1.57 & 0.27 & 33.37 & 0.24 \\
\hline 1200 & 10740 & 300 & 722 & 20 & 0.90 & 0.30 & 110.2 & 6.4 & 1.42 & 0.34 & 33.25 & 0.36 \\
\hline 1240 & 12090 & 180 & 823 & 13 & 0.40 & 0.40 & 115.2 & 6.8 & 1.15 & 0.35 & 33.20 & 0.31 \\
\hline 1300 & 12880 & 210 & 884 & 15 & 1.20 & 0.40 & 116.2 & 5.0 & 1.03 & 0.35 & 33.08 & 0.31 \\
\hline 1360 & 10920 & 230 & 762 & 16 & 0.70 & 0.40 & 123.9 & 7.5 & 0.01 & 0.01 & 33.28 & 0.65 \\
\hline 1420 & 10330 & 280 & 710 & 19 & 0.50 & 0.40 & 101.4 & 6.5 & 0.07 & 0.07 & 33.77 & 0.64 \\
\hline 1500 & 9960 & 470 & 647 & 31 & 1.00 & 0.50 & 93.8 & 7.5 & 1.20 & 1.20 & 34.46 & 1.46 \\
\hline 1550 & 16320 & 80 & 842 & 6 & 4.00 & 0.70 & 131.5 & 5.8 & 16.90 & 2.10 & 31.24 & 1.71 \\
\hline 1600 & 21330 & 110 & 1169 & 7 & 4.30 & 0.90 & 178.0 & 11.0 & 17.80 & 2.80 & 31.92 & 1.63 \\
\hline 1650 & 33920 & 160 & 1597 & 9 & 8.10 & 1.20 & 234.0 & 13.0 & 39.00 & 4.60 & 32.60 & 1.98 \\
\hline 1700 & 62680 & 250 & 2297 & 11 & 19.70 & 1.80 & 347.0 & 18.0 & 102.30 & 7.00 & 32.83 & 2.08 \\
\hline 1750 & 23570 & 320 & 543 & 8 & 9.90 & 2.70 & 58.0 & 25.0 & 52.50 & 9.90 & 34.53 & 12.41 \\
\hline Total & 356600 & 1200 & 17993 & 71 & 77.20 & 3.90 & 2669.0 & 43.0 & 340.60 & 13.60 & 33.06 & 0.52 \\
\hline
\end{tabular}




\begin{tabular}{|c|c|c|c|c|c|c|c|c|c|c|c|c|}
\hline $\begin{array}{l}\text { Temp. } \\
\left({ }^{\circ} \mathrm{C}\right)\end{array}$ & ${ }^{40} \mathrm{Ar}$ & $\pm^{40} \mathrm{Ar}$ & ${ }^{39} \mathrm{Ar}$ & $\pm^{39} \mathrm{Ar}$ & ${ }^{38} \mathrm{Ar}$ & $\pm^{38} \mathrm{Ar}$ & ${ }^{37} \mathrm{Ar}$ & $\pm^{37} \mathrm{Ar}$ & ${ }^{36} \mathrm{Ar}$ & $\pm{ }^{36} \mathrm{Ar}$ & $\begin{array}{c}\text { Age } \\
\text { (Ma) }\end{array}$ & $\begin{array}{l} \pm \text { Age } \\
\text { (Ma) }\end{array}$ \\
\hline 600 & 1020 & 10 & 2 & 1 & 0.90 & 0.10 & 4 & 4 & 3.36 & 0.11 & 29.91 & 32.82 \\
\hline 800 & 16180 & 60 & 187 & 1 & 8.80 & 0.30 & 46 & 13 & 44.11 & 0.58 & 38.67 & 2.02 \\
\hline 900 & 5530 & 20 & 235 & 2 & 1.40 & 0.10 & 48 & 14 & 6.70 & 0.12 & 34.71 & 0.40 \\
\hline 960 & 4570 & 20 & 208 & 2 & 1.10 & 0.10 & 31 & 10 & 4.71 & 0.13 & 35.10 & 0.50 \\
\hline 1040 & 6630 & 30 & 365 & 2 & 1.20 & 0.20 & 58 & 9 & 3.67 & 0.16 & 34.99 & 0.34 \\
\hline 1125 & 12970 & 310 & 819 & 20 & 1.10 & 0.30 & 95 & 9 & 1.97 & 0.15 & 34.80 & 0.18 \\
\hline 1150 & 13700 & 330 & 909 & 22 & 0.80 & 0.30 & 97 & 9 & 0.02 & 0.02 & 34.65 & 0.19 \\
\hline 1200 & 18200 & 440 & 1201 & 29 & 1.20 & 0.40 & 155 & 16 & - & - & 34.86 & 0.14 \\
\hline 1240 & 17860 & 440 & 1169 & 29 & 1.20 & 0.40 & 167 & 14 & 0.01 & 0.01 & 35.15 & 0.19 \\
\hline 1300 & 16480 & 430 & 1082 & 28 & 0.60 & 0.40 & 153 & 14 & 0.07 & 0.07 & 34.98 & 0.22 \\
\hline 1320 & 17070 & 450 & 1130 & 30 & 1.00 & 0.40 & 185 & 14 & 0.04 & 0.04 & 34.72 & 0.27 \\
\hline 1350 & 16370 & 450 & 1077 & 30 & 0.40 & 0.40 & 118 & 10 & - & - & 34.97 & 0.21 \\
\hline 1380 & 15140 & 30 & 995 & 3 & 0.80 & 0.40 & 97 & 13 & - & - & 35.02 & 0.11 \\
\hline 1400 & 11930 & 20 & 786 & 2 & 0.60 & 0.30 & 74 & 14 & 0.05 & 0.05 & 34.88 & 0.25 \\
\hline 1440 & 9070 & 20 & 592 & 3 & 0.50 & 0.30 & 94 & 11 & 0.07 & 0.07 & 35.16 & 0.39 \\
\hline 1480 & 7840 & 20 & 521 & 2 & 0.50 & 0.20 & 54 & 11 & 0.02 & 0.02 & 34.58 & 0.56 \\
\hline 1520 & 6850 & 20 & 451 & 2 & 0.30 & 0.30 & 71 & 11 & 0.07 & 0.07 & 34.81 & 0.82 \\
\hline 1600 & 21480 & 50 & 774 & 3 & 6.90 & 0.40 & 86 & 11 & 34.20 & 1.10 & 33.81 & 1.00 \\
\hline 1700 & 82560 & 110 & 2917 & 6 & 26.50 & 1.20 & 399 & 23 & 132.50 & 2.70 & 34.24 & 0.62 \\
\hline 1750 & 41420 & 80 & 857 & 3 & 18.60 & 0.80 & 109 & 22 & 101.60 & 3.10 & 30.63 & 2.40 \\
\hline Total & 342900 & 1100 & 16278 & 73 & 74.40 & 2.00 & 2143 & 60 & 333.20 & 4.30 & 34.55 & 0.18 \\
\hline
\end{tabular}


Table A9 ${ }^{40} \mathrm{Ar} /{ }^{39} \mathrm{Ar}$ step heating results for core fragment Be281-Bc2 $\times 10^{-11} \mathrm{ccSTP} / \mathrm{g}$. Uncertainties at $1 \sigma$ level. $\quad \mathrm{J}=0,001281 \pm 0,000016$

\begin{tabular}{|c|c|c|c|c|c|c|c|c|c|c|c|c|}
\hline $\begin{array}{l}\text { Temp. } \\
\left({ }^{\circ} \mathrm{C}\right)\end{array}$ & ${ }^{40} \mathrm{Ar}$ & $\pm^{40} \mathrm{Ar}$ & ${ }^{39} \mathrm{Ar}$ & $\pm{ }^{39} \mathrm{Ar}$ & ${ }^{38} \mathrm{Ar}$ & $\pm^{38} \mathrm{Ar}$ & ${ }^{37} \mathrm{Ar}$ & $\pm^{37} \mathrm{Ar}$ & ${ }^{36} \mathrm{Ar}$ & $\pm^{36} \mathrm{Ar}$ & $\begin{array}{c}\text { Age } \\
\text { (Ma) }\end{array}$ & $\begin{array}{l} \pm \text { Age } \\
\text { (Ma) }\end{array}$ \\
\hline 600 & 23740 & 410 & 245 & 5 & 13.10 & 0.50 & 42 & 9 & 65.75 & 1.38 & 39.62 & 2.18 \\
\hline 800 & 2200 & 50 & 72 & 2 & 0.50 & 0.10 & 12 & 6 & 3.83 & 0.21 & 33.48 & 1.76 \\
\hline 880 & 2790 & 60 & 182 & 5 & 0.40 & 0.10 & 20 & 5 & 0.01 & 0.01 & 34.81 & 0.69 \\
\hline 940 & 2960 & 60 & 200 & 4 & 0.20 & 0.10 & 22 & 6 & 0.01 & 0.01 & 33.50 & 0.55 \\
\hline 1000 & 5170 & 100 & 330 & 7 & 0.30 & 0.20 & 41 & 4 & 0.08 & 0.08 & 35.47 & 0.38 \\
\hline 1050 & 7150 & 60 & 475 & 5 & 0.50 & 0.20 & 53 & 4 & 0.01 & 0.01 & 34.18 & 0.26 \\
\hline 1090 & 27230 & 230 & 1787 & 15 & 0.90 & 0.60 & 222 & 10 & 0.01 & 0.01 & 34.63 & 0.14 \\
\hline 1120 & 25930 & 220 & 1721 & 15 & 1.10 & 0.60 & 210 & 8 & 0.07 & 0.07 & 34.21 & 0.14 \\
\hline 1150 & 15640 & 130 & 1036 & 9 & 1.00 & 0.50 & 131 & 8 & - & - & 34.31 & 0.11 \\
\hline 1180 & 15340 & 140 & 1012 & 9 & 0.80 & 0.40 & 118 & 6 & 0.03 & 0.03 & 34.45 & 0.21 \\
\hline 1210 & 12880 & 30 & 852 & 3 & 0.80 & 0.40 & 108 & 8 & 0.03 & 0.03 & 34.35 & 0.21 \\
\hline 1240 & 12950 & 30 & 844 & 3 & 0.80 & 0.40 & 108 & 5 & 0.04 & 0.04 & 34.82 & 0.21 \\
\hline 1300 & 19990 & 50 & 1307 & 5 & 1.40 & 0.50 & 151 & 9 & - & - & 34.74 & 0.12 \\
\hline 1360 & 26780 & 50 & 1759 & 6 & 1.80 & 0.60 & 227 & 8 & - & - & 34.60 & 0.12 \\
\hline 1420 & 13010 & 50 & 857 & 5 & 1.30 & 0.50 & 108 & 8 & 0.04 & 0.04 & 34.46 & 0.52 \\
\hline 1500 & 9900 & 50 & 633 & 4 & 0.70 & 0.40 & 70 & 9 & 0.01 & 0.01 & 35.56 & 1.20 \\
\hline 1550 & 5960 & 50 & 387 & 4 & 0.50 & 0.50 & 59 & 8 & 0.04 & 0.04 & 34.88 & 2.12 \\
\hline 1600 & 8380 & 70 & 523 & 5 & 0.40 & 0.40 & 54 & 9 & 0.04 & 0.04 & 36.35 & 2.17 \\
\hline 1650 & 10470 & 110 & 704 & 8 & 0.00 & 0.00 & 80 & 9 & 0.08 & 0.08 & 33.73 & 2.57 \\
\hline 1700 & 10680 & 140 & 687 & 9 & 0.00 & 0.00 & 78 & 12 & 0.06 & 0.06 & 35.25 & 3.81 \\
\hline Total & 259150 & 620 & 15615 & 33 & 26.20 & 1.80 & 1914 & 35 & 70.11 & 1.40 & 34.69 & 0.24 \\
\hline
\end{tabular}


Table $\mathrm{A} 10^{40} \mathrm{Ar} /{ }^{39} \mathrm{Ar}$ step heating results for core fragment Be281-Bc3 $\times 10^{-11} \mathrm{ccSTP} / \mathrm{g}$. Uncertainties at $1 \sigma$ level. $\quad \mathrm{J}=0,0004731 \pm 0,0000032$

\begin{tabular}{|c|c|c|c|c|c|c|c|c|c|c|c|c|}
\hline $\begin{array}{l}\text { Temp. } \\
\left({ }^{\circ} \mathrm{C}\right)\end{array}$ & ${ }^{40} \mathrm{Ar}$ & $\pm^{40} \mathrm{Ar}$ & ${ }^{39} \mathrm{Ar}$ & $\pm^{39} \mathrm{Ar}$ & ${ }^{38} \mathrm{Ar}$ & $\pm^{38} \mathrm{Ar}$ & ${ }^{37} \mathrm{Ar}$ & $\pm^{37} \mathrm{Ar}$ & ${ }^{36} \mathrm{Ar}$ & $\pm^{36} \mathrm{Ar}$ & $\begin{array}{l}\text { Age } \\
\text { (Ma) }\end{array}$ & $\begin{array}{l} \pm \text { Age } \\
\text { (Ma) }\end{array}$ \\
\hline 600 & 577 & 23 & 1.5 & 0.2 & 0.26 & 0.07 & 6.5 & 8.2 & 1.56 & 0.11 & 65.37 & 16.65 \\
\hline 800 & 11243 & 483 & 39.9 & 1.8 & 6.52 & 0.35 & 14.6 & 16.9 & 31.19 & 1.39 & 42.52 & 2.44 \\
\hline 900 & 3133 & 138 & 57.2 & 2.6 & 0.66 & 0.10 & 12.8 & 12.9 & 2.21 & 0.18 & 36.38 & 0.72 \\
\hline 960 & 4395 & 191 & 83.2 & 3.7 & 0.92 & 0.13 & 9.7 & 11.4 & 3.39 & 0.19 & 34.23 & 0.44 \\
\hline 1000 & 4269 & 186 & 75.8 & 3.3 & 0.73 & 0.13 & 6.0 & 10.2 & 3.95 & 0.25 & 34.33 & 0.60 \\
\hline 1030 & 3857 & 168 & 80.7 & 3.6 & 0.36 & 0.09 & 13.9 & 13.9 & 1.94 & 0.16 & 34.13 & 0.45 \\
\hline 1060 & 4523 & 197 & 106.6 & 4.7 & 0.30 & 0.13 & 35.3 & 12.3 & 0.34 & 0.09 & 34.80 & 0.33 \\
\hline 1090 & 13801 & 120 & 244.4 & 2.3 & 2.50 & 0.21 & 17.9 & 9.7 & 13.00 & 0.25 & 34.20 & 0.26 \\
\hline 1120 & 10239 & 89 & 238.9 & 2.5 & 0.68 & 0.16 & 36.9 & 11.3 & 1.21 & 0.13 & 34.71 & 0.24 \\
\hline 1150 & 14514 & 127 & 346.2 & 3.7 & 0.49 & 0.19 & 71.1 & 23.2 & 1.09 & 0.15 & 34.40 & 0.23 \\
\hline 1180 & 11442 & 101 & 265.8 & 2.5 & 0.85 & 0.16 & 70.9 & 11.5 & 1.43 & 0.12 & 34.78 & 0.15 \\
\hline 1210 & 9864 & 88 & 225.2 & 2.4 & 0.48 & 0.13 & 43.4 & 12.8 & 2.04 & 0.14 & 34.51 & 0.27 \\
\hline 1240 & 9967 & 90 & 227.0 & 2.5 & 0.70 & 0.21 & 15.0 & 10.0 & 2.18 & 0.20 & 34.45 & 0.29 \\
\hline 1280 & 10853 & 169 & 220.6 & 3.8 & 1.28 & 0.19 & 21.7 & 14.1 & 6.06 & 0.25 & 34.47 & 0.35 \\
\hline 1320 & 8377 & 135 & 204.5 & 3.6 & 0.21 & 0.13 & 19.3 & 12.6 & 0.01 & 0.13 & 34.37 & 0.23 \\
\hline 1360 & 7535 & 125 & 183.6 & 3.2 & 0.01 & 0.16 & 22.6 & 17.3 & 0.01 & 0.16 & 34.45 & 0.17 \\
\hline 1400 & 5636 & 101 & 139.4 & 2.7 & 0.07 & 0.11 & 6.8 & 9.6 & 0.01 & 0.14 & 33.92 & 0.23 \\
\hline 1450 & 4320 & 90 & 105.9 & 2.4 & 0.35 & 0.12 & 16.0 & 14.7 & 0.00 & 0.19 & 34.22 & 0.26 \\
\hline 1500 & 4722 & 96 & 112.0 & 2.5 & 0.00 & 0.14 & 28.8 & 9.5 & 0.17 & 0.30 & 34.98 & 0.73 \\
\hline 1550 & 4526 & 108 & 112.2 & 3.1 & 0.00 & 0.14 & 22.2 & 14.5 & 0.00 & 0.34 & 33.84 & 0.45 \\
\hline 1600 & 6027 & 154 & 146.8 & 4.3 & 0.06 & 0.23 & 12.7 & 16.9 & 0.01 & 0.49 & 34.44 & 0.48 \\
\hline 1650 & 7485 & 209 & 175.7 & 5.7 & 0.25 & 0.25 & 49.4 & 18.0 & 0.01 & 0.66 & 35.71 & 1.08 \\
\hline 1700 & 9334 & 316 & 217.9 & 8.8 & 0.32 & 0.34 & 31.7 & 31.8 & 0.15 & 1.11 & 35.77 & 1.47 \\
\hline 1750 & 19910 & 595 & 483.8 & 16.9 & 0.30 & 0.60 & 67.7 & 45.8 & 0.02 & 1.79 & 34.53 & 0.62 \\
\hline Total & 190549 & 1038 & 4095 & 24 & 18.3 & 1.1 & 653 & 85 & 72.0 & 2.8 & 34.69 & 0.13 \\
\hline
\end{tabular}




\begin{tabular}{|c|c|c|c|c|c|c|c|c|c|c|c|c|}
\hline $\begin{array}{l}\text { Temp. } \\
\left({ }^{\circ} \mathrm{C}\right)\end{array}$ & ${ }^{40} \mathrm{Ar}$ & $\pm^{40} \mathrm{Ar}$ & ${ }^{39} \mathrm{Ar}$ & $\pm{ }^{39} \mathrm{Ar}$ & ${ }^{38} \mathrm{Ar}$ & $\pm^{38} \mathrm{Ar}$ & ${ }^{37} \mathrm{Ar}$ & $\pm^{37} \mathrm{Ar}$ & ${ }^{36} \mathrm{Ar}$ & $\pm^{36} \mathrm{Ar}$ & $\begin{array}{c}\text { Age } \\
\text { (Ma) }\end{array}$ & $\begin{array}{l} \pm \text { Age } \\
\text { (Ma) }\end{array}$ \\
\hline 600 & 1110 & 400 & 6 & 2 & 1.0 & 0.4 & 30 & 30 & 3.60 & 1.30 & 22.91 & 14.79 \\
\hline 800 & 168900 & 42500 & 201 & 51 & 97.0 & 24.0 & 800 & 240 & 456.30 & 114.90 & 340.29 & 10.03 \\
\hline 900 & 9300 & 2500 & 360 & 96 & 2.3 & 0.6 & 50 & 50 & 11.00 & 3.00 & 36.51 & 0.76 \\
\hline 960 & 9300 & 2500 & 480 & 130 & 1.6 & 0.5 & 20 & 20 & 6.30 & 1.70 & 34.06 & 0.59 \\
\hline 1040 & 18000 & 30 & 924 & 4 & 3.1 & 0.4 & 190 & 70 & 12.05 & 0.44 & 34.21 & 0.34 \\
\hline 1100 & 41300 & 70 & 2604 & 9 & 1.7 & 0.9 & 370 & 90 & 3.37 & 0.24 & 33.90 & 0.14 \\
\hline 1150 & 46340 & 80 & 3000 & 12 & 2.1 & 1.0 & 560 & 100 & 0.13 & 0.13 & 33.80 & 0.16 \\
\hline 1200 & 30600 & 60 & 1987 & 6 & 1.6 & 0.7 & 400 & 80 & - & - & 33.73 & 0.11 \\
\hline 1250 & 33220 & 60 & 2145 & 7 & 1.6 & 0.8 & 230 & 100 & 0.05 & 0.05 & 33.90 & 0.14 \\
\hline 1300 & 35530 & 60 & 2280 & 7 & 1.5 & 0.8 & 250 & 120 & - & - & 34.12 & 0.16 \\
\hline 1350 & 38210 & 70 & 2450 & 11 & 2.0 & 0.9 & 520 & 100 & - & - & 34.15 & 0.15 \\
\hline 1400 & 26130 & 70 & 1674 & 7 & 0.7 & 0.7 & 110 & 70 & 0.05 & 0.05 & 34.15 & 0.33 \\
\hline 1500 & 27040 & 40 & 875 & 6 & 9.8 & 0.7 & 40 & 40 & 44.93 & 0.79 & 34.45 & 0.62 \\
\hline 1600 & 83590 & 170 & 3837 & 14 & 18.0 & 1.9 & 640 & 100 & 83.20 & 1.90 & 33.67 & 0.34 \\
\hline 1700 & 85860 & 250 & 4128 & 25 & 13.0 & 1.6 & 330 & 120 & 66.10 & 4.40 & 35.16 & 0.71 \\
\hline Total & 654400 & 42700 & 26950 & 170 & 157.0 & 25.0 & 4530 & 400 & 687.10 & 115.10 & 36.65 & 0.64 \\
\hline
\end{tabular}


Table A12 ${ }^{40} \mathrm{Ar} /{ }^{39} \mathrm{Ar}$ step heating results for rim fragment Be281-Br2 $\times 10^{-11} \mathrm{ccSTP} / \mathrm{g}$. Uncertainties at $1 \sigma$ level. $\quad \mathrm{J}=0,001206 \pm 0,000014$

\begin{tabular}{|c|c|c|c|c|c|c|c|c|c|c|c|c|}
\hline $\begin{array}{l}\text { Temp. } \\
\left({ }^{\circ} \mathrm{C}\right)\end{array}$ & ${ }^{40} \mathrm{Ar}$ & $\pm^{40} \mathrm{Ar}$ & ${ }^{39} \mathrm{Ar}$ & $\pm^{39} \mathrm{Ar}$ & ${ }^{38} \mathrm{Ar}$ & $\pm^{38} \mathrm{Ar}$ & ${ }^{37} \mathrm{Ar}$ & $\pm^{37} \mathrm{Ar}$ & ${ }^{36} \mathrm{Ar}$ & $\pm{ }^{36} \mathrm{Ar}$ & $\begin{array}{l}\text { Age } \\
\text { (Ma) }\end{array}$ & $\begin{array}{l} \pm \text { Age } \\
\text { (Ma) }\end{array}$ \\
\hline 600 & 560 & 10 & 4 & 1 & 0.60 & 0.10 & 20 & 10 & 2.16 & 0.12 & 0.00 & 0.00 \\
\hline 800 & 20270 & 40 & 125 & 1 & 11.60 & 0.20 & 30 & 20 & 61.48 & 0.71 & 36.17 & 3.52 \\
\hline 900 & 3570 & 10 & 189 & 1 & 0.70 & 0.10 & 10 & 10 & 2.10 & 0.19 & 33.30 & 0.66 \\
\hline 960 & 3090 & 10 & 188 & 1 & 0.50 & 0.10 & 40 & 20 & 0.64 & 0.15 & 32.97 & 0.53 \\
\hline 1040 & 6450 & 20 & 395 & 2 & 0.40 & 0.20 & 50 & 20 & 1.06 & 0.17 & 33.26 & 0.33 \\
\hline 1100 & 21690 & 50 & 1385 & 5 & 1.40 & 0.50 & 200 & 20 & 0.43 & 0.16 & 33.31 & 0.13 \\
\hline 1150 & 24740 & 60 & 1576 & 6 & 1.40 & 0.60 & 260 & 30 & 0.01 & 0.01 & 33.57 & 0.13 \\
\hline 1200 & 15900 & 40 & 1019 & 4 & 0.30 & 0.30 & 120 & 20 & - & - & 33.37 & 0.12 \\
\hline 1250 & 17100 & 40 & 1099 & 4 & 0.60 & 0.60 & 140 & 20 & 0.01 & 0.01 & 33.29 & 0.17 \\
\hline 1300 & 15830 & 30 & 1010 & 3 & 0.40 & 0.40 & 150 & 20 & 0.07 & 0.07 & 33.47 & 0.18 \\
\hline 1350 & 17830 & 30 & 1127 & 4 & 0.60 & 0.50 & 130 & 20 & 0.06 & 0.06 & 33.82 & 0.16 \\
\hline 1400 & 19070 & 40 & 1218 & 4 & 1.70 & 0.50 & 180 & 20 & 0.06 & 0.06 & 33.46 & 0.21 \\
\hline 1500 & 9100 & 20 & 591 & 3 & 0.20 & 0.20 & 80 & 20 & 0.09 & 0.09 & 32.85 & 0.52 \\
\hline 1600 & 23750 & 60 & 1552 & 5 & 0.60 & 0.60 & 180 & 40 & - & - & 32.75 & 0.50 \\
\hline 1700 & 56840 & 120 & 3651 & 12 & 1.90 & 1.40 & 390 & 50 & - & - & 33.31 & 0.50 \\
\hline 1750 & 12240 & 110 & 810 & 8 & 0.60 & 0.60 & 50 & 40 & 0.01 & 0.01 & 32.31 & 2.97 \\
\hline Total & 268030 & 220 & 15938 & 19 & 23.40 & 2.10 & 2040 & 110 & 68.20 & 0.81 & 33.28 & 0.16 \\
\hline
\end{tabular}




\begin{tabular}{|c|c|c|c|c|c|c|c|c|c|c|c|c|}
\hline $\begin{array}{l}\text { Temp. } \\
\left({ }^{\circ} \mathrm{C}\right)\end{array}$ & ${ }^{40} \mathrm{Ar}$ & $\pm^{40} \mathrm{Ar}$ & ${ }^{39} \mathrm{Ar}$ & $\pm^{39} \mathrm{Ar}$ & ${ }^{38} \mathrm{Ar}$ & $\pm^{38} \mathrm{Ar}$ & ${ }^{37} \mathrm{Ar}$ & $\pm^{37} \mathrm{Ar}$ & ${ }^{36} \mathrm{Ar}$ & $\pm^{36} \mathrm{Ar}$ & $\begin{array}{c}\text { Age } \\
\text { (Ma) }\end{array}$ & $\begin{array}{l} \pm \text { Age } \\
\text { (Ma) }\end{array}$ \\
\hline 600 & 1670 & 20 & 16 & 1 & 1.00 & 0.20 & 5 & 5 & 4.58 & 0.21 & 50.22 & 9.01 \\
\hline 800 & 22990 & 240 & 661 & 7 & 10.60 & 0.40 & 83 & 9 & 46.47 & 0.82 & 35.16 & 0.74 \\
\hline 900 & 13370 & 150 & 825 & 10 & 2.10 & 0.40 & 108 & 8 & 6.77 & 0.30 & 34.60 & 0.31 \\
\hline 1000 & 19550 & 210 & 1167 & 13 & 4.10 & 0.50 & 158 & 10 & 10.57 & 0.34 & 35.32 & 0.25 \\
\hline 1100 & 40280 & 440 & 2773 & 31 & 4.90 & 1.20 & 361 & 20 & 6.96 & 0.37 & 34.62 & 0.16 \\
\hline 1140 & 24480 & 680 & 1766 & 49 & 2.00 & 0.70 & 238 & 18 & - & - & 34.79 & 0.11 \\
\hline 1200 & 38000 & 1000 & 2719 & 75 & 3.00 & 1.00 & 333 & 15 & - & - & 35.05 & 0.15 \\
\hline 1240 & 46100 & 1300 & 3311 & 92 & 0.70 & 0.70 & 386 & 19 & - & - & 34.97 & 0.15 \\
\hline 1280 & 41400 & 1200 & 2985 & 86 & 3.50 & 1.10 & 366 & 18 & - & - & 34.83 & 0.12 \\
\hline 1340 & 33300 & 1100 & 2419 & 76 & 2.70 & 0.80 & 311 & 18 & - & - & 34.60 & 0.11 \\
\hline 1400 & 26000 & 1000 & 1873 & 75 & 2.90 & 0.70 & 257 & 15 & - & - & 34.84 & 0.12 \\
\hline 1460 & 23200 & 1200 & 1703 & 86 & 1.90 & 0.70 & 219 & 15 & 0.04 & 0.04 & 34.18 & 0.36 \\
\hline 1520 & 18000 & 1400 & 1350 & 110 & 1.80 & 0.70 & 181 & 19 & 0.05 & 0.05 & 33.49 & 0.78 \\
\hline 1600 & 32900 & 2700 & 2150 & 180 & 3.10 & 1.30 & 279 & 34 & 8.80 & 3.00 & 35.37 & 1.00 \\
\hline 1700 & 89200 & 6000 & 3820 & 260 & 27.00 & 2.50 & 465 & 37 & 126.30 & 9.70 & 34.17 & 0.91 \\
\hline 1750 & 8100 & 2600 & 670 & 220 & 0.60 & 0.60 & 68 & 26 & 1.10 & 1.10 & 29.25 & 3.44 \\
\hline Total & 478600 & 7800 & 30200 & 450 & 71.90 & 4.00 & 3816 & 79 & 211.60 & 10.20 & 34.59 & 0.17 \\
\hline
\end{tabular}




\begin{tabular}{|c|c|c|c|c|c|c|c|c|c|c|c|c|}
\hline $\begin{array}{l}\text { Temp. } \\
\left({ }^{\circ} \mathrm{C}\right)\end{array}$ & ${ }^{40} \mathrm{Ar}$ & $\pm^{40} \mathrm{Ar}$ & ${ }^{39} \mathrm{Ar}$ & $\pm^{39} \mathrm{Ar}$ & ${ }^{38} \mathrm{Ar}$ & $\pm^{38} \mathrm{Ar}$ & ${ }^{37} \mathrm{Ar}$ & $\pm^{37} \mathrm{Ar}$ & ${ }^{36} \mathrm{Ar}$ & $\pm^{36} \mathrm{Ar}$ & $\begin{array}{l}\text { Age } \\
\text { (Ma) }\end{array}$ & $\begin{array}{l} \pm \text { Age } \\
\text { (Ma) }\end{array}$ \\
\hline 600 & 1230 & 10 & 15 & 1 & 0.70 & 0.10 & 95 & 81 & 3.4 & 0.2 & 36.83 & 10.63 \\
\hline 800 & 23240 & 110 & 218 & 1 & 13.70 & 0.30 & 178 & 65 & 68.7 & 0.8 & 33.68 & 2.51 \\
\hline 900 & 6320 & 30 & 250 & 2 & 2.60 & 0.20 & 140 & 56 & 9.5 & 0.3 & 35.15 & 0.81 \\
\hline 960 & 3620 & 20 & 242 & 2 & 0.40 & 0.20 & 7 & 7 & 1.2 & 0.1 & 33.75 & 0.48 \\
\hline 1040 & 4940 & 30 & 350 & 2 & 0.50 & 0.20 & 113 & 66 & 0.6 & 0.2 & 34.16 & 0.44 \\
\hline 1100 & 14650 & 120 & 1018 & 9 & 1.40 & 0.40 & 205 & 46 & 2.5 & 0.2 & 34.30 & 0.19 \\
\hline 1150 & 19930 & 170 & 1434 & 12 & 1.60 & 0.60 & 320 & 100 & 0.7 & 0.1 & 34.54 & 0.13 \\
\hline 1200 & 15310 & 130 & 1111 & 10 & 1.50 & 0.40 & 110 & 65 & - & - & 34.56 & 0.12 \\
\hline 1250 & 15030 & 140 & 1081 & 11 & 0.60 & 0.40 & 175 & 55 & 0.6 & 0.3 & 34.43 & 0.26 \\
\hline 1300 & 16620 & 160 & 1212 & 12 & 1.30 & 0.50 & 271 & 39 & 0.3 & 0.3 & 34.21 & 0.22 \\
\hline 1350 & 14810 & 150 & 1079 & 11 & 0.90 & 0.40 & 282 & 62 & - & - & 34.43 & 0.13 \\
\hline 1400 & 12010 & 200 & 876 & 15 & 1.90 & 0.60 & 210 & 74 & - & - & 34.39 & 0.13 \\
\hline 1500 & 15900 & 30 & 1151 & 4 & 1.50 & 0.50 & 133 & 62 & - & - & 34.64 & 0.37 \\
\hline 1600 & 25770 & 70 & 1770 & 6 & 1.90 & 0.70 & 181 & 65 & 4.8 & 1.6 & 34.49 & 0.67 \\
\hline 1700 & 56300 & 130 & 3734 & 14 & 7.40 & 1.50 & 200 & 130 & 16.5 & 3.5 & 34.53 & 0.69 \\
\hline 1750 & 12650 & 70 & 950 & 7 & 1.30 & 0.80 & 19 & 19 & 0.4 & 0.4 & 33.09 & 2.76 \\
\hline Total & 258320 & 460 & 16493 & 35 & 39.00 & 2.30 & 2650 & 270 & 109.3 & 4.0 & 34.38 & 0.24 \\
\hline
\end{tabular}




\begin{tabular}{|c|c|c|c|c|c|c|c|c|c|c|c|c|}
\hline $\begin{array}{l}\text { Temp. } \\
\left({ }^{\circ} \mathrm{C}\right)\end{array}$ & ${ }^{40} \mathrm{Ar}$ & $\pm^{40} \mathrm{Ar}$ & ${ }^{39} \mathrm{Ar}$ & $\pm^{39} \mathrm{Ar}$ & ${ }^{38} \mathrm{Ar}$ & $\pm^{38} \mathrm{Ar}$ & ${ }^{37} \mathrm{Ar}$ & $\pm{ }^{37} \mathrm{Ar}$ & ${ }^{36} \mathrm{Ar}$ & $\pm^{36} \mathrm{Ar}$ & $\begin{array}{l}\text { Age } \\
\text { (Ma) }\end{array}$ & $\begin{array}{l} \pm \text { Age } \\
\text { (Ma) }\end{array}$ \\
\hline 600 & 6900 & 100 & 164 & 2 & 6.7 & 0.5 & 14 & 11 & 14.9 & 0.5 & 36.54 & 2.19 \\
\hline 700 & 40500 & 100 & 289 & 2 & 23.9 & 0.6 & 45 & 14 & 122.4 & 1.4 & 36.98 & 3.29 \\
\hline 800 & 22800 & 100 & 646 & 5 & 8.8 & 0.7 & 59 & 14 & 45.5 & 0.9 & 35.35 & 0.96 \\
\hline 880 & 15500 & 200 & 801 & 10 & 4.3 & 0.5 & 79 & 15 & 13.5 & 0.6 & 35.11 & 0.52 \\
\hline 940 & 13700 & 200 & 700 & 9 & 2.8 & 0.5 & 69 & 15 & 12.5 & 0.7 & 34.66 & 0.75 \\
\hline 1000 & 24300 & 300 & 1151 & 14 & 4.9 & 0.7 & 86 & 13 & 25.6 & 1.0 & 35.30 & 0.60 \\
\hline 1050 & 20100 & 200 & 1416 & 18 & 2.2 & 0.7 & 115 & 13 & - & - & 34.55 & 0.27 \\
\hline 1090 & 25500 & 300 & 1818 & 22 & 2.4 & 0.7 & 187 & 16 & - & - & 34.13 & 0.20 \\
\hline 1120 & 27900 & 300 & 1981 & 25 & 1.1 & 0.8 & 211 & 13 & - & - & 34.20 & 0.29 \\
\hline 1150 & 22800 & 300 & 1605 & 21 & 1.8 & 0.9 & 113 & 27 & - & - & 34.63 & 0.28 \\
\hline 1180 & 44000 & 100 & 1839 & 8 & 13.2 & 0.9 & 196 & 16 & 57.9 & 1.1 & 35.65 & 0.43 \\
\hline 1210 & 27100 & 100 & 1915 & 9 & 1.3 & 0.7 & 208 & 20 & - & - & 34.45 & 0.26 \\
\hline 1240 & 26600 & 100 & 1756 & 9 & 3.3 & 0.9 & 155 & 20 & 2.9 & 1.1 & 35.67 & 0.48 \\
\hline 1300 & 20500 & 100 & 1327 & 8 & 3.1 & 1 & 130 & 15 & 5.0 & 1.1 & 34.88 & 0.61 \\
\hline 1360 & 10400 & 100 & 735 & 6 & 1.7 & 0.7 & 73 & 12 & 0.1 & 0.1 & 34.45 & 1.36 \\
\hline 1420 & 8800 & 100 & 462 & 6 & 1.1 & 0.8 & 50 & 14 & 5.3 & 1.8 & 38.00 & 2.81 \\
\hline 1500 & 24800 & 200 & 391 & 4 & 13.4 & 1 & 45 & 11 & 67.9 & 2.9 & 29.49 & 5.32 \\
\hline 1600 & 674600 & 1100 & 1529 & 6 & 414.1 & 3.4 & 251 & 21 & 2242.0 & 18.0 & 19.49 & 8.47 \\
\hline 1700 & 250000 & 800 & 60 & 2 & 155.8 & 2.9 & 26 & 22 & 859.0 & 14.0 & 0.00 & 0.00 \\
\hline 1750 & 416600 & 1100 & 91 & 2 & 265.3 & 4.1 & 2 & 2 & 1413.0 & 20.0 & 0.00 & 0.00 \\
\hline Total & 1723400 & 1900 & 20675 & 52 & 931.2 & 6.9 & 2114 & 71 & 4888.0 & 31.0 & 33.45 & 1.05 \\
\hline
\end{tabular}




\begin{tabular}{|c|c|c|c|c|c|c|c|c|c|c|c|c|}
\hline $\begin{array}{l}\text { Temp. } \\
\left({ }^{\circ} \mathrm{C}\right)\end{array}$ & ${ }^{40} \mathrm{Ar}$ & $\pm^{40} \mathrm{Ar}$ & ${ }^{39} \mathrm{Ar}$ & $\pm^{39} \mathrm{Ar}$ & ${ }^{38} \mathrm{Ar}$ & $\pm^{38} \mathrm{Ar}$ & ${ }^{37} \mathrm{Ar}$ & $\pm^{37} \mathrm{Ar}$ & ${ }^{36} \mathrm{Ar}$ & $\pm^{36} \mathrm{Ar}$ & $\begin{array}{l}\text { Age } \\
\text { (Ma) }\end{array}$ & $\begin{array}{l} \pm \text { Age } \\
\text { (Ma) }\end{array}$ \\
\hline 600 & 1802 & 62 & 5.3 & 0.2 & 1.034 & 0.102 & 0.2 & 12.4 & 5.469 & 0.243 & 42.19 & 10.28 \\
\hline 700 & 957 & 34 & 26.5 & 1.0 & 0.117 & 0.059 & 9.7 & 9.8 & 0.433 & 0.113 & 37.41 & 1.57 \\
\hline 800 & 9614 & 316 & 55.2 & 1.9 & 5.220 & 0.218 & 11.5 & 13.5 & 26.419 & 0.909 & 39.11 & 1.77 \\
\hline 900 & 3836 & 128 & 103.2 & 3.5 & 0.698 & 0.114 & 21.1 & 15.4 & 3.134 & 0.173 & 33.75 & 0.52 \\
\hline 960 & 4482 & 149 & 129.0 & 4.3 & 0.480 & 0.104 & 25.1 & 11.7 & 2.591 & 0.138 & 34.48 & 0.35 \\
\hline 1000 & 5076 & 168 & 131.9 & 4.4 & 1.036 & 0.122 & 40.1 & 11.7 & 4.629 & 0.220 & 33.65 & 0.47 \\
\hline 1030 & 5257 & 99 & 150.4 & 3.0 & 0.699 & 0.116 & 4.7 & 8.9 & 3.517 & 0.191 & 33.57 & 0.46 \\
\hline 1060 & 5448 & 103 & 182.9 & 3.6 & 0.452 & 0.131 & 20.7 & 14.7 & 0.997 & 0.132 & 33.73 & 0.30 \\
\hline 1090 & 16313 & 305 & 541.1 & 10.4 & 1.028 & 0.213 & 31.0 & 16.3 & 3.556 & 0.146 & 33.76 & 0.17 \\
\hline 1120 & 11609 & 217 & 401.8 & 7.7 & 0.534 & 0.221 & 12.8 & 12.8 & 1.184 & 0.073 & 33.55 & 0.14 \\
\hline 1150 & 13568 & 254 & 472.0 & 9.0 & 1.004 & 0.204 & 54.3 & 13.6 & 0.990 & 0.137 & 33.66 & 0.16 \\
\hline 1180 & 8879 & 168 & 305.3 & 5.9 & 0.435 & 0.160 & 32.0 & 23.1 & 0.888 & 0.108 & 33.78 & 0.20 \\
\hline 1210 & 6869 & 18 & 239.5 & 1.6 & 0.227 & 0.179 & 4.1 & 12.4 & 0.398 & 0.364 & 33.74 & 0.57 \\
\hline 1240 & 5319 & 9 & 183.5 & 1.1 & 0.255 & 0.128 & 8.5 & 10.1 & 0.378 & 0.144 & 33.97 & 0.33 \\
\hline 1300 & 7900 & 13 & 277.5 & 1.2 & 0.158 & 0.142 & 37.1 & 11.1 & 0.119 & 0.111 & 33.91 & 0.19 \\
\hline 1360 & 16361 & 24 & 578.5 & 2.6 & 0.164 & 0.262 & 45.8 & 16.4 & 0.016 & 0.131 & 33.84 & 0.14 \\
\hline 1420 & 26870 & 37 & 948.8 & 3.5 & 0.484 & 0.403 & 75.2 & 26.9 & 0.027 & 0.188 & 33.89 & 0.12 \\
\hline 1500 & 20266 & 33 & 719.4 & 3.3 & 0.162 & 0.385 & 109.4 & 16.2 & 0.020 & 0.223 & 33.72 & 0.14 \\
\hline 1560 & 4870 & 157 & 171.1 & 6.2 & 0.341 & 0.181 & 17.5 & 18.5 & 0.005 & 0.409 & 34.06 & 0.55 \\
\hline 1620 & 4510 & 179 & 156.2 & 7.2 & 0.149 & 0.212 & 32.0 & 22.6 & 0.027 & 0.465 & 34.49 & 1.33 \\
\hline 1680 & 6098 & 289 & 227.6 & 13.0 & 0.006 & 0.274 & 16.5 & 26.2 & 0.006 & 0.842 & 32.07 & 1.00 \\
\hline 1740 & 14797 & 554 & 507.5 & 21.8 & 0.015 & 0.444 & 13.3 & 37.0 & 0.015 & 1.361 & 34.88 & 0.72 \\
\hline 1800 & 6670 & 633 & 227.4 & 27.9 & 0.007 & 0.647 & 9.3 & 60.0 & 0.267 & 2.341 & 34.68 & 4.50 \\
\hline Total & 207371 & 1130 & 6742 & 44 & 14.7 & 1.2 & 632 & 103 & 55.1 & 3.1 & 33.93 & 0.18 \\
\hline
\end{tabular}


Table $A 17{ }^{40} \mathrm{Ar} /{ }^{39} \mathrm{Ar}$ step heating results for CB-W61 $\times 10^{-11} \mathrm{ccSTP} / \mathrm{g}$. Uncertainties at $1 \sigma$ level. $\quad \mathrm{J}=0.001305 \pm 0.000018$

\begin{tabular}{|c|c|c|c|c|c|c|c|c|c|c|c|c|c|c|}
\hline $\begin{array}{l}\text { Temp. } \\
\left({ }^{\circ} \mathrm{C}\right)\end{array}$ & ${ }^{40} \mathrm{Ar}$ & $\pm^{40} \mathrm{Ar}$ & ${ }^{39} \mathrm{Ar}$ & $\pm^{39} \mathrm{Ar}$ & ${ }^{38} \mathrm{Ar}$ & $\pm^{38} \mathrm{Ar}$ & ${ }^{37} \mathrm{Ar}$ & $\pm^{37} \mathrm{Ar}$ & ${ }^{36} \mathrm{Ar}$ & $\pm^{36} \mathrm{Ar}$ & $\begin{array}{c}\text { Age } \\
(\mathrm{Ma}) \\
{ }^{40} \mathrm{Ar}^{36} \mathrm{Ar}_{\mathrm{i}}= \\
{ }^{295.5 \pm 0.5}\end{array}$ & $\begin{array}{l} \pm \text { Age } \\
\text { (Ma) }\end{array}$ & $\begin{array}{c}\text { Age } \\
(\mathrm{Ma}) \\
\begin{array}{c}{ }^{40} \mathrm{Ar} 3^{66} \mathrm{Ar}= \\
343.5 \pm 2.0\end{array}\end{array}$ & $\begin{array}{l} \pm \text { Age } \\
\text { (Ma) }\end{array}$ \\
\hline 400 & 120776 & 1066 & 2.5 & 0.1 & 67.2 & 0.7 & 199.3 & 45.9 & 365.7 & 3.6 & 3627 & 112 & - & - \\
\hline 600 & 2999696 & 26552 & 321.0 & 4.1 & 1643.8 & 15.7 & 4619.5 & 126.8 & 9938.0 & 96.2 & 411 & 74 & - & - \\
\hline 650 & 118159 & 330 & 92.6 & 0.4 & 62.6 & 0.4 & 274.1 & 40.2 & 329.8 & 2.2 & 458 & 12 & - & - \\
\hline 700 & 410599 & 1158 & 628.2 & 2.7 & 217.2 & 1.0 & 1506.9 & 74.0 & 1161.2 & 7.7 & 235.1 & 6.9 & - & - \\
\hline 740 & 450882 & 1279 & 858.0 & 3.0 & 230.9 & 1.1 & 1573.6 & 72.3 & 1236.3 & 7.6 & 219.0 & 5.2 & 34.83 & 10.57 \\
\hline 780 & 889682 & 2517 & 1792.7 & 6.2 & 445.7 & 2.2 & 1850.5 & 80.2 & 2461.8 & 15.8 & 199.9 & 5.0 & 22.91 & 10.15 \\
\hline 800 & 292107 & 825 & 665.4 & 2.6 & 146.3 & 1.0 & 815.0 & 70.1 & 793.1 & 5.2 & 192.1 & 4.5 & 38.77 & 8.83 \\
\hline 830 & 368619 & 1060 & 771.2 & 3.1 & 186.2 & 1.2 & 936.3 & 77.5 & 1002.3 & 6.6 & 207.2 & 4.9 & 40.85 & 9.61 \\
\hline 860 & 411527 & 1260 & 725.5 & 3.6 & 210.3 & 1.0 & 716.1 & 98.8 & 1133.3 & 7.8 & 231.2 & 6.0 & 32.11 & 11.80 \\
\hline 900 & 413123 & 4470 & 755.2 & 8.4 & 210.3 & 2.4 & 764.3 & 50.3 & 1140.6 & 13.6 & 221.3 & 4.9 & 28.16 & 10.62 \\
\hline 940 & 342058 & 3701 & 952.6 & 10.7 & 173.1 & 2.0 & 632.8 & 65.4 & 930.4 & 11.1 & 157.6 & 3.4 & 30.53 & 6.97 \\
\hline 990 & 251369 & 2726 & 1922.5 & 21.2 & 118.9 & 1.5 & 799.4 & 53.5 & 630.7 & 7.7 & 77.34 & 1.28 & 33.72 & 2.40 \\
\hline 1020 & 96189 & 1043 & 1463.6 & 16.2 & 42.0 & 0.7 & 357.8 & 57.8 & 217.5 & 2.7 & 50.28 & 0.65 & 30.35 & 1.14 \\
\hline 1075 & 72338 & 785 & 1528.8 & 17.1 & 28.9 & 0.6 & 350.8 & 50.8 & 145.0 & 1.8 & 44.53 & 0.42 & 31.80 & 0.73 \\
\hline 1100 & 126565 & 1372 & 3016.9 & 33.3 & 49.0 & 1.1 & 834.1 & 45.2 & 243.6 & 2.9 & 41.78 & 0.31 & 30.92 & 0.58 \\
\hline 1150 & 107902 & 1170 & 2128.5 & 23.6 & 45.2 & 0.9 & 752.1 & 68.5 & 226.4 & 2.8 & 44.47 & 0.45 & 30.18 & 0.80 \\
\hline 1190 & 56068 & 610 & 952.1 & 10.7 & 24.7 & 0.4 & 402.0 & 32.3 & 122.8 & 1.5 & 47.88 & 0.60 & 30.56 & 1.01 \\
\hline 1220 & 18516 & 35 & 286.0 & 1.1 & 8.0 & 0.1 & 144.1 & 35.6 & 40.9 & 0.3 & 51.79 & 0.75 & 32.62 & 1.20 \\
\hline 1240 & 11294 & 22 & 180.1 & 0.7 & 4.9 & 0.1 & 76.2 & 45.0 & 24.6 & 0.2 & 51.62 & 0.87 & 33.36 & 1.29 \\
\hline 1280 & 15921 & 31 & 255.4 & 1.0 & 7.0 & 0.2 & 155.4 & 28.7 & 34.2 & 0.3 & 52.56 & 0.72 & 34.66 & 1.13 \\
\hline 1320 & 11485 & 25 & 194.5 & 0.9 & 5.0 & 0.1 & 110.7 & 30.2 & 24.8 & 0.2 & 49.43 & 0.76 & 32.37 & 1.15 \\
\hline 1370 & 8693 & 19 & 163.9 & 0.6 & 3.9 & 0.1 & 140.2 & 37.0 & 17.8 & 0.2 & 48.13 & 0.88 & 33.54 & 1.22 \\
\hline 1400 & 7698 & 19 & 135.9 & 0.7 & 3.4 & 0.1 & 54.5 & 31.6 & 16.4 & 0.2 & 48.14 & 1.12 & 31.91 & 1.50 \\
\hline 1500 & 3334 & 15 & 82.8 & 0.6 & 1.1 & 0.1 & 13.2 & 27.5 & 5.0 & 0.2 & 51.44 & 1.63 & 43.33 & 1.98 \\
\hline 1600 & 7110 & 28 & 134.5 & 0.7 & 3.0 & 0.1 & 159.5 & 42.1 & 13.2 & 1.0 & 55.01 & 5.10 & 41.92 & 6.18 \\
\hline 1750 & 19518 & 42 & 253.6 & 1.2 & 9.7 & 0.3 & 67.9 & 70.3 & 50.8 & 1.0 & 41.14 & 2.62 & 14.10 & 3.38 \\
\hline Total & 7631228 & 27666 & 20264 & 55 & 3948 & 17 & 18306 & 310 & 22306 & 101 & 116.12 & 1.58 & 29.75 & 3.53 \\
\hline
\end{tabular}


Table A18 ${ }^{40} \mathrm{Ar} /{ }^{39} \mathrm{Ar}$ step heating results for CB-W-61-2 $\times 10^{-11} \mathrm{cCSTP} / \mathrm{g}$. Uncertainties at $1 \sigma$ level. J=0.0006747 \pm 00000067

\begin{tabular}{|c|c|c|c|c|c|c|c|c|c|c|c|c|c|c|c|c|}
\hline $\begin{array}{l}\text { Temp. } \\
\left({ }^{\circ} \mathrm{C}\right)\end{array}$ & ${ }^{40} \mathrm{Ar}$ & $\pm^{40} \mathrm{Ar}$ & ${ }^{39} \mathrm{Ar}$ & $\pm^{39} \mathrm{Ar}$ & ${ }^{38} \mathrm{Ar}$ & $\pm^{38} \mathrm{Ar}$ & ${ }^{37} \mathrm{Ar}$ & $\pm^{37} \mathrm{Ar}$ & ${ }^{36} \mathrm{Ar}$ & $\pm^{36} \mathrm{Ar}$ & $\begin{array}{c}\text { Age } \\
(\mathrm{Ma}) \\
{ }^{40} \mathrm{Ar}^{36} \mathrm{Ar}= \\
295.5 \pm 0.5\end{array}$ & $\begin{array}{l} \pm \text { Age } \\
\text { (Ma) }\end{array}$ & $\begin{array}{c}\text { Age } \\
(\mathrm{Ma}) \\
{ }^{40} \mathrm{Ar} \mathrm{Ar}^{36} \mathrm{Ar}= \\
327.3 \pm 6.3\end{array}$ & $\begin{array}{l} \pm \text { Age } \\
(\mathrm{Ma})\end{array}$ & $\begin{array}{c}\text { Age } \\
(\mathrm{Ma}) \\
{ }^{40} \mathrm{Ar} r^{36 \mathrm{Ar}}= \\
363.8 \pm 5.4\end{array}$ & $\begin{array}{l} \pm \text { Age } \\
\text { (Ma) }\end{array}$ \\
\hline 500 & 105476 & 2250 & 3.3 & 0.4 & 60.0 & 1.4 & 8.9 & 4.1 & 315.8 & 7.5 & 2264.6 & 197.94 & 653.65 & 593.86 & - & - \\
\hline 600 & 2016135 & 40341 & 270.2 & 6.7 & 1100.8 & 22.8 & 246.0 & 24.7 & 5943.6 & 130.0 & 902.14 & 44.38 & 293.73 & 157.73 & - & - \\
\hline 700 & 672624 & 18251 & 394.8 & 13.0 & 369.3 & 10.4 & 265.7 & 14.1 & 1891.4 & 54.9 & 320.33 & 16.05 & 157.99 & 38.28 & - & - \\
\hline 750 & 1010312 & 21099 & 832.5 & 18.4 & 535.5 & 11.6 & 343.5 & 18.6 & 2776.3 & 63.2 & 258.25 & 9.78 & 142.77 & 26.15 & 0.41 & 25.70 \\
\hline 800 & 582349 & 13522 & 661.5 & 15.8 & 302.8 & 7.4 & 216.1 & 15.4 & 1536.8 & 38.5 & 221.70 & 7.20 & 140.38 & 18.38 & 42.28 & 17.70 \\
\hline 830 & 862807 & 17966 & 589.3 & 12.7 & 454.7 & 9.8 & 244.2 & 10.8 & 2321.0 & 52.9 & 332.83 & 11.27 & 201.40 & 30.02 & 37.70 & 29.91 \\
\hline 860 & 214442 & 4519 & 250.3 & 5.6 & 113.2 & 2.6 & 63.7 & 6.2 & 574.1 & 13.3 & 205.73 & 7.41 & 124.73 & 18.41 & 27.03 & 17.75 \\
\hline 890 & 265880 & 5589 & 295.1 & 6.4 & 142.0 & 3.1 & 67.8 & 8.4 & 718.1 & 16.5 & 208.78 & 7.41 & 122.87 & 19.35 & 18.95 & 18.65 \\
\hline 920 & 245501 & 5291 & 316.5 & 7.1 & 128.9 & 3.0 & 82.5 & 9.5 & 650.8 & 15.3 & 193.76 & 6.47 & 120.81 & 16.44 & 33.28 & 15.72 \\
\hline 950 & 251055 & 5359 & 449.1 & 9.8 & 132.3 & 3.0 & 120.8 & 10.6 & 661.3 & 15.4 & 144.83 & 4.76 & 91.46 & 11.97 & 28.18 & 11.31 \\
\hline 980 & 128627 & 3049 & 426.4 & 10.5 & 67.4 & 1.8 & 86.1 & 5.5 & 322.9 & 8.4 & 92.43 & 2.78 & 64.37 & 6.38 & 31.61 & 5.97 \\
\hline 1010 & 116857 & 2527 & 777.6 & 17.2 & 60.3 & 1.7 & 134.7 & 10.0 & 275.8 & 6.6 & 54.52 & 1.30 & 41.15 & 3.01 & 25.69 & 2.79 \\
\hline 1040 & 59883 & 1424 & 526.8 & 12.9 & 31.1 & 1.0 & 96.1 & 8.2 & 130.4 & 3.4 & 48.69 & 1.01 & 39.34 & 2.15 & 28.55 & 2.00 \\
\hline 1070 & 73668 & 1559 & 717.1 & 15.5 & 38.0 & 1.2 & 133.8 & 9.9 & 160.3 & 3.8 & 44.10 & 0.83 & 35.63 & 1.90 & 25.87 & 1.76 \\
\hline 1100 & 101237 & 2352 & 964.6 & 24.3 & 52.6 & 1.7 & 223.8 & 10.3 & 216.8 & 5.7 & 46.29 & 1.10 & 37.79 & 2.05 & 27.98 & 1.93 \\
\hline 1130 & 117702 & 2492 & 959.5 & 20.5 & 63.2 & 1.8 & 242.9 & 7.1 & 270.5 & 6.3 & 47.29 & 1.01 & 36.63 & 2.39 & 24.32 & 2.21 \\
\hline 1160 & 73758 & 1684 & 487.7 & 11.3 & 40.4 & 1.1 & 127.2 & 7.7 & 178.6 & 4.5 & 51.64 & 1.41 & 37.82 & 3.15 & 21.82 & 2.94 \\
\hline 1190 & 36181 & 876 & 196.6 & 5.0 & 20.7 & 0.6 & 61.0 & 5.6 & 92.6 & 2.4 & 53.73 & 1.80 & 35.94 & 4.05 & 15.31 & 3.77 \\
\hline 1220 & 36908 & 799 & 185.8 & 4.5 & 21.0 & 0.6 & 65.8 & 5.9 & 95.6 & 2.3 & 55.79 & 1.98 & 36.37 & 4.42 & 13.82 & 4.10 \\
\hline 1250 & 38446 & 833 & 168.2 & 3.7 & 21.3 & 0.6 & 55.3 & 5.6 & 101.0 & 2.4 & 61.27 & 2.27 & 38.67 & 5.15 & 12.38 & 4.82 \\
\hline 1350 & 35662 & 792 & 93.7 & 2.2 & 20.4 & 0.5 & 33.5 & 3.7 & 101.0 & 2.5 & 74.05 & 4.03 & 33.55 & 9.27 & - & - \\
\hline 1500 & 43723 & 980 & 33.4 & 0.9 & 27.1 & 0.7 & 12.5 & 7.5 & 139.8 & 3.5 & 85.89 & 15.92 & - & - & - & - \\
\hline 1750 & 96750 & 2147 & 22.3 & 1.1 & 59.9 & 1.5 & 0.4 & 14.3 & 315.7 & 7.7 & 179.33 & 47.74 & - & - & - & - \\
\hline Total & 7185983 & 55387 & 9622 & 57 & 3863 & 31 & 2932 & 52 & 19790 & 172 & 153.21 & 1.92 & & & & \\
\hline
\end{tabular}


Table A19 ${ }^{40} \mathrm{Ar} /{ }^{39} \mathrm{Ar}$ step heating results for CB-W84 $\times 10^{-11} \mathrm{ccSTP} / \mathrm{g}$. Uncertainties at $1 \sigma$ level. $\quad \mathrm{J}=0,001268 \pm 0,000018$

\begin{tabular}{|c|c|c|c|c|c|c|c|c|c|c|c|c|c|c|}
\hline $\begin{array}{l}\text { Temp. } \\
\left({ }^{\circ} \mathrm{C}\right)\end{array}$ & ${ }^{40} \mathrm{Ar}$ & $\pm^{40} \mathrm{Ar}$ & ${ }^{39} \mathrm{Ar}$ & $\pm^{39} \mathrm{Ar}$ & ${ }^{38} \mathrm{Ar}$ & $\pm^{38} \mathrm{Ar}$ & ${ }^{37} \mathrm{Ar}$ & $\pm^{37} \mathrm{Ar}$ & ${ }^{36} \mathrm{Ar}$ & $\pm^{36} \mathrm{Ar}$ & $\begin{array}{c}\text { Age } \\
(\mathrm{Ma}) \\
{ }^{40} \mathrm{Ar}^{36} \mathrm{Ar}_{\mathrm{i}}= \\
295.5 \pm 0.5\end{array}$ & $\begin{array}{l} \pm \text { Age } \\
\text { (Ma) }\end{array}$ & $\begin{array}{c}\text { Age } \\
(\mathrm{Ma}) \\
{ }^{40} \mathrm{Ar}^{36} \mathrm{Ar}_{\mathrm{i}}= \\
332.0 \pm 7.3\end{array}$ & $\begin{array}{l} \pm \text { Age } \\
\text { (Ma) }\end{array}$ \\
\hline 400 & 128600 & 234 & 46.4 & 0.4 & 72.1 & 0.5 & 501.5 & 64.3 & 389.8 & 2.7 & 559 & 28 & - & - \\
\hline 550 & 199773 & 377 & 264.5 & 1.7 & 113.1 & 0.8 & 1018.8 & 119.9 & 589.5 & 3.6 & 207 & 8 & 34.39 & 37.46 \\
\hline 650 & 109801 & 172 & 1000.0 & 3.5 & 56.2 & 0.6 & 823.5 & 98.8 & 283.4 & 2.3 & 58.24 & 1.51 & 35.36 & 4.90 \\
\hline 740 & 143844 & 301 & 3275.5 & 11.9 & 54.2 & 1.2 & 1323.4 & 172.6 & 265.8 & 2.2 & 44.70 & 0.47 & 38.12 & 1.41 \\
\hline 800 & 58231 & 145 & 1718.9 & 8.3 & 17.8 & 0.6 & 617.2 & 122.3 & 86.6 & 0.9 & 42.59 & 0.38 & 38.50 & 0.91 \\
\hline 860 & 39785 & 84 & 933.5 & 3.4 & 15.1 & 0.4 & 580.9 & 119.4 & 71.8 & 0.7 & 44.63 & 0.49 & 38.41 & 1.36 \\
\hline 900 & 18820 & 59 & 371.0 & 2.1 & 7.8 & 0.2 & 532.6 & 86.6 & 38.1 & 0.4 & 45.70 & 0.74 & 37.39 & 1.85 \\
\hline 940 & 30761 & 57 & 533.1 & 2.1 & 13.4 & 0.3 & 412.2 & 76.9 & 66.0 & 0.5 & 47.36 & 0.67 & 37.34 & 2.14 \\
\hline 1000 & 63198 & 98 & 1161.8 & 4.2 & 27.6 & 0.5 & 739.4 & 120.1 & 132.8 & 1.0 & 46.22 & 0.61 & 36.97 & 1.97 \\
\hline 1100 & 233957 & 342 & 3892.6 & 11.2 & 100.8 & 1.4 & 1357.0 & 93.6 & 521.3 & 3.6 & 46.02 & 0.63 & 35.16 & 2.28 \\
\hline 1150 & 126012 & 178 & 1820.5 & 6.9 & 57.0 & 0.8 & 655.3 & 88.2 & 291.3 & 1.9 & 49.11 & 0.71 & 36.15 & 2.71 \\
\hline 1200 & 94833 & 75 & 1270.9 & 4.3 & 43.3 & 0.7 & 303.5 & 94.8 & 218.0 & 1.8 & 53.51 & 0.94 & 39.66 & 2.97 \\
\hline 1240 & 50730 & 66 & 608.7 & 2.1 & 23.7 & 0.4 & 380.5 & 96.4 & 117.8 & 1.1 & 58.36 & 1.18 & 42.75 & 3.39 \\
\hline 1300 & 25667 & 32 & 285.3 & 1.2 & 12.7 & 0.2 & 25.7 & 74.4 & 60.0 & 0.5 & 62.12 & 1.16 & 45.20 & 3.63 \\
\hline 1370 & 15005 & 19 & 150.4 & 0.9 & 7.0 & 0.1 & 93.0 & 72.0 & 34.7 & 0.5 & 70.46 & 2.15 & 52.00 & 4.42 \\
\hline 1450 & 10031 & 24 & 138.0 & 0.9 & 4.2 & 0.4 & 56.2 & 73.2 & 20.3 & 0.5 & 65.33 & 2.31 & 53.55 & 3.50 \\
\hline 1600 & 4344 & 30 & 104.9 & 1.1 & 0.9 & 0.3 & 246.7 & 78.6 & 4.6 & 0.8 & 63.15 & 4.93 & 59.60 & 5.58 \\
\hline 1750 & 16273 & 83 & 119.4 & 1.1 & 8.4 & 0.6 & 190.4 & 203.4 & 47.7 & 2.6 & 41.04 & 14.5 & 8.38 & 17.80 \\
\hline Total & 1369665 & 728 & 17695 & 22 & 635 & 3 & 9858 & 462 & 3240 & 8 & 52.15 & 0.30 & 37.45 & 1.02 \\
\hline
\end{tabular}


Table A20 ${ }^{40} \mathrm{Ar} /{ }^{39} \mathrm{Ar}$ step heating results for CB-W84-2 $\times 10^{-11} \mathrm{ccSTP} / \mathrm{g}$. Uncertainties at $1 \sigma$ level. J=0,0006528 $\pm 0,0000044$

\begin{tabular}{|c|c|c|c|c|c|c|c|c|c|c|c|c|c|c|}
\hline $\begin{array}{l}\text { Temp. } \\
\left({ }^{\circ} \mathrm{C}\right)\end{array}$ & ${ }^{40} \mathrm{Ar}$ & $\pm^{40} \mathrm{Ar}$ & ${ }^{39} \mathrm{Ar}$ & $\pm^{39} \mathrm{Ar}$ & ${ }^{38} \mathrm{Ar}$ & $\pm^{38} \mathrm{Ar}$ & ${ }^{37} \mathrm{Ar}$ & $\pm^{37} \mathrm{Ar}$ & ${ }^{36} \mathrm{Ar}$ & $\pm{ }^{36} \mathrm{Ar}$ & $\begin{array}{c}\text { Age } \\
(\mathrm{Ma}) \\
{ }^{40} \mathrm{~A} \mathrm{Ar}^{36 \mathrm{~A}} \mathrm{rr}_{\mathrm{i}}= \\
295.5 \pm 0.5\end{array}$ & $\begin{array}{l} \pm \text { Age } \\
\text { (Ma) }\end{array}$ & $\begin{array}{c}\text { Age } \\
(\mathrm{Ma}) \\
{ }^{40} \mathrm{M} \mathrm{r} \mathrm{P}^{6 \mathrm{~A}} \mathrm{Ar}= \\
329.6 \pm 5.6\end{array}$ & $\begin{array}{l} \pm \text { Age } \\
\text { (Ma) }\end{array}$ \\
\hline 500 & 403227 & 8265 & 219.0 & 5.3 & 235.48 & 5.40 & 246.0 & 16.9 & 1199.6 & 27.1 & 244.80 & 16.19 & 41.68 & 40.37 \\
\hline 600 & 123556 & 3459 & 490.4 & 15.7 & 74.26 & 2.36 & 248.3 & 19.8 & 331.0 & 10.0 & 60.79 & 2.82 & 34.39 & 5.31 \\
\hline 700 & 120487 & 2587 & 1201.1 & 26.5 & 66.27 & 1.94 & 286.8 & 12.5 & 255.4 & 6.4 & 43.60 & 0.95 & 35.24 & 1.73 \\
\hline 750 & 50143 & 1259 & 636.3 & 16.5 & 26.27 & 1.16 & 211.1 & 16.9 & 87.9 & 2.8 & 44.22 & 0.93 & 38.80 & 1.36 \\
\hline 800 & 55426 & 1178 & 827.3 & 18.1 & 28.38 & 1.17 & 190.7 & 19.8 & 85.9 & 2.3 & 42.26 & 0.59 & 38.18 & 0.93 \\
\hline 830 & 28946 & 686 & 355.2 & 9.4 & 15.17 & 0.73 & 98.7 & 12.9 & 51.5 & 1.4 & 44.92 & 0.84 & 39.23 & 1.28 \\
\hline 860 & 24551 & 538 & 255.7 & 6.1 & 13.43 & 0.57 & 88.9 & 13.6 & 51.3 & 1.5 & 42.73 & 1.40 & 34.84 & 2.01 \\
\hline 890 & 11189 & 1044 & 121.5 & 15.6 & 6.10 & 0.64 & 28.1 & 8.3 & 21.4 & 2.5 & 46.49 & 5.96 & 39.58 & 6.10 \\
\hline 920 & 20901 & 437 & 163.8 & 3.6 & 11.85 & 0.37 & 43.7 & 8.6 & 49.1 & 1.1 & 45.48 & 1.10 & 33.71 & 2.28 \\
\hline 950 & 16559 & 366 & 126.2 & 2.9 & 8.69 & 0.28 & 38.7 & 4.4 & 39.6 & 1.1 & 44.74 & 1.73 & 32.40 & 2.79 \\
\hline 980 & 23563 & 494 & 181.4 & 3.9 & 12.87 & 0.39 & 66.7 & 6.7 & 54.7 & 1.4 & 47.42 & 1.40 & 35.59 & 2.49 \\
\hline 1010 & 22209 & 484 & 169.1 & 3.8 & 12.17 & 0.46 & 48.2 & 7.8 & 50.5 & 1.3 & 49.94 & 1.33 & 38.23 & 2.42 \\
\hline 1040 & 46989 & 967 & 407.6 & 8.8 & 25.70 & 0.84 & 110.0 & 10.6 & 102.5 & 2.4 & 47.63 & 1.03 & 37.77 & 1.97 \\
\hline 1070 & 56039 & 1184 & 441.7 & 9.7 & 30.21 & 0.85 & 101.4 & 9.2 & 128.8 & 3.1 & 47.28 & 1.12 & 35.84 & 2.25 \\
\hline 1100 & 99200 & 2351 & 722.5 & 18.9 & 51.48 & 1.57 & 132.9 & 11.4 & 229.9 & 6.1 & 50.24 & 1.42 & 37.76 & 2.56 \\
\hline 1130 & 75358 & 1667 & 459.2 & 10.5 & 40.02 & 1.07 & 100.2 & 7.9 & 181.2 & 4.4 & 55.06 & 1.44 & 39.63 & 2.99 \\
\hline 1160 & 46508 & 1067 & 262.7 & 6.2 & 24.88 & 0.66 & 50.7 & 8.9 & 113.6 & 2.8 & 57.13 & 1.49 & 40.23 & 3.23 \\
\hline 1190 & 31754 & 726 & 164.5 & 3.9 & 18.07 & 0.56 & 57.8 & 8.7 & 79.0 & 2.1 & 59.14 & 2.25 & 40.38 & 3.98 \\
\hline 1220 & 24265 & 542 & 117.9 & 2.8 & 13.61 & 0.44 & 29.8 & 7.3 & 60.3 & 1.5 & 63.16 & 2.23 & 43.19 & 4.11 \\
\hline 1250 & 16829 & 386 & 73.4 & 1.8 & 8.95 & 0.31 & 31.6 & 7.3 & 42.4 & 1.2 & 67.82 & 3.01 & 45.35 & 4.99 \\
\hline 1350 & 31600 & 675 & 122.0 & 2.7 & 17.29 & 0.53 & 34.8 & 7.6 & 82.4 & 2.0 & 68.54 & 2.42 & 42.23 & 5.11 \\
\hline 1500 & 40407 & 888 & 74.1 & 1.7 & 24.24 & 0.62 & 29.9 & 5.7 & 118.2 & 2.9 & 84.85 & 5.54 & 22.70 & 12.13 \\
\hline 1750 & 85690 & 1895 & 12.5 & 0.8 & 54.67 & 1.43 & 12.0 & 19.7 & 290.7 & 7.2 & -18.9 & -95.0 & -1353 & -411 \\
\hline Total & 1455396 & 10497 & 7605 & 52 & 820 & 7 & 2287 & 57 & 3707 & 32 & 54.57 & 1.68 & 35.11 & 2.92 \\
\hline
\end{tabular}



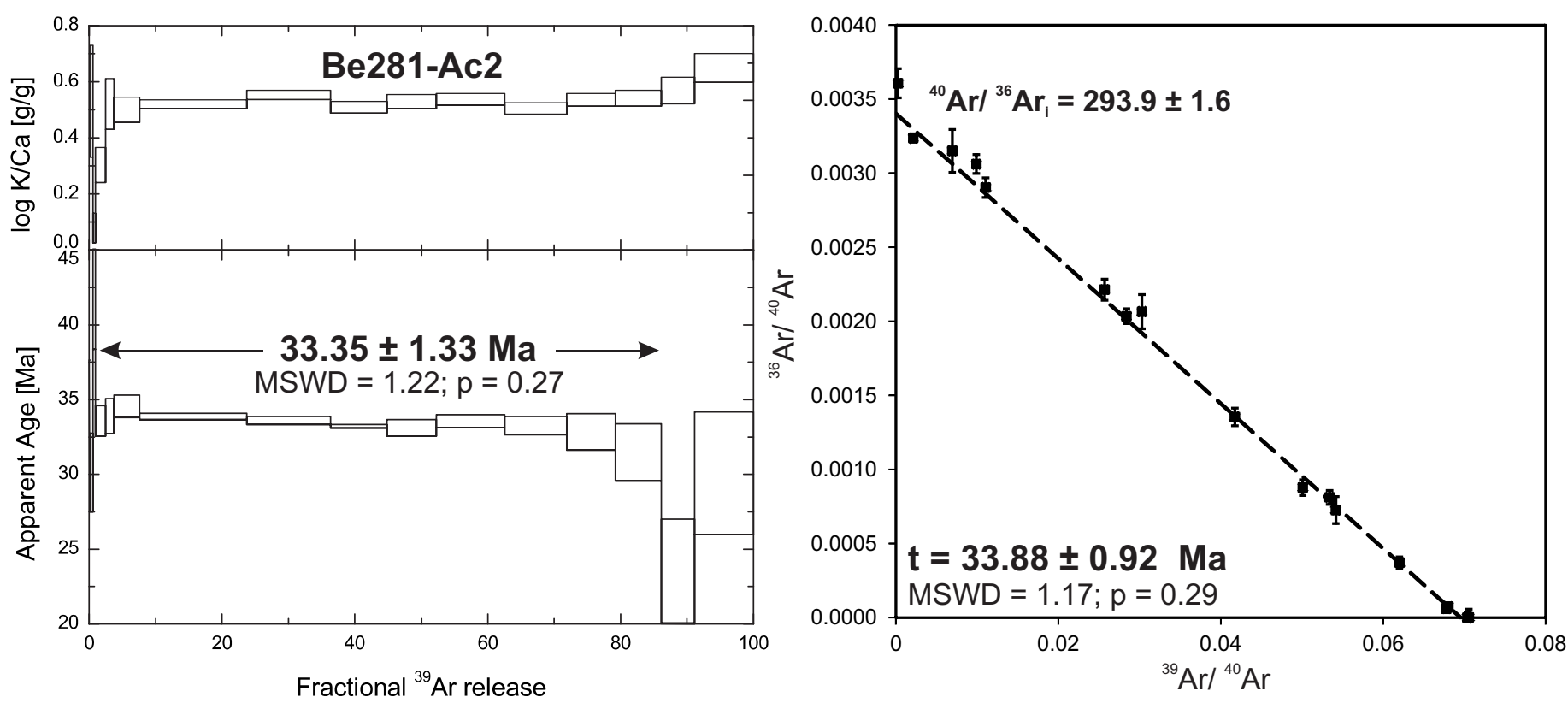

Figure A1-A 

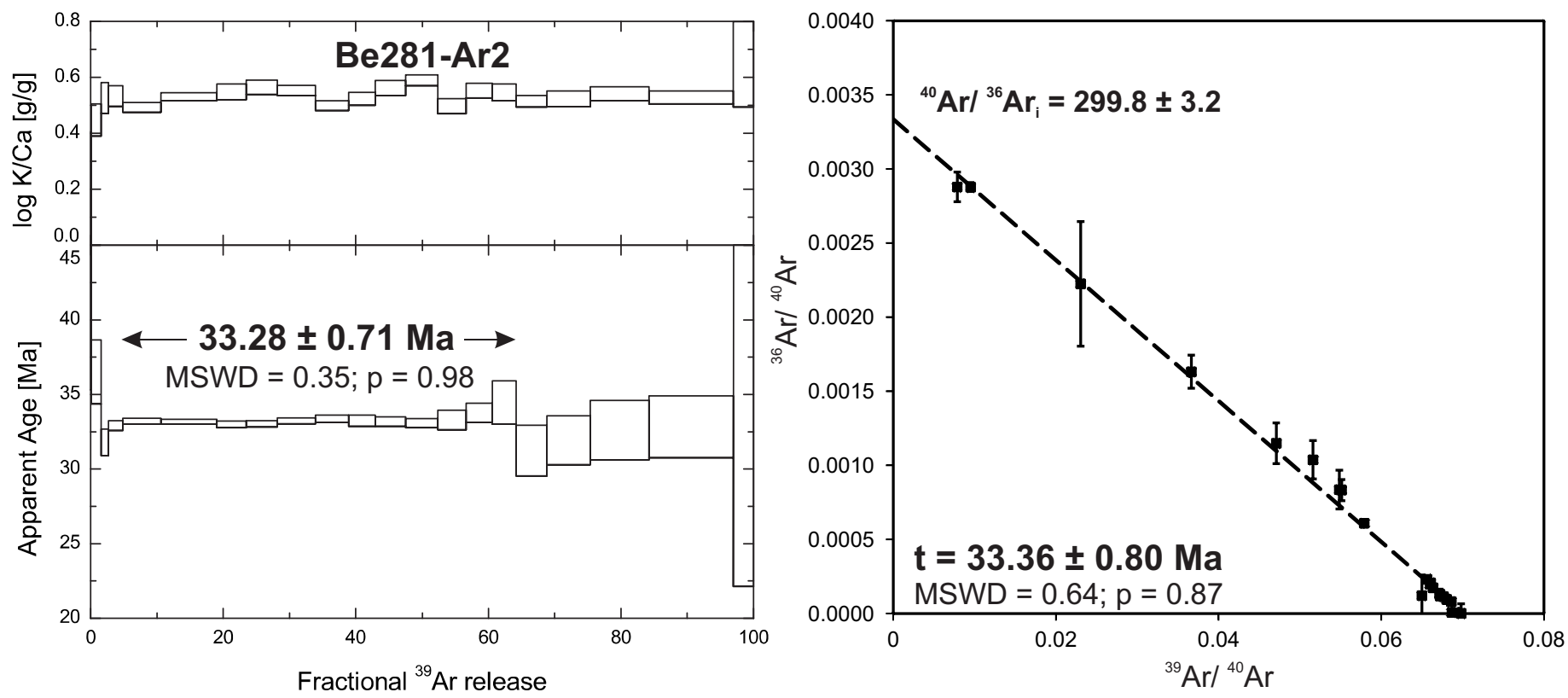

Figure A1-B 

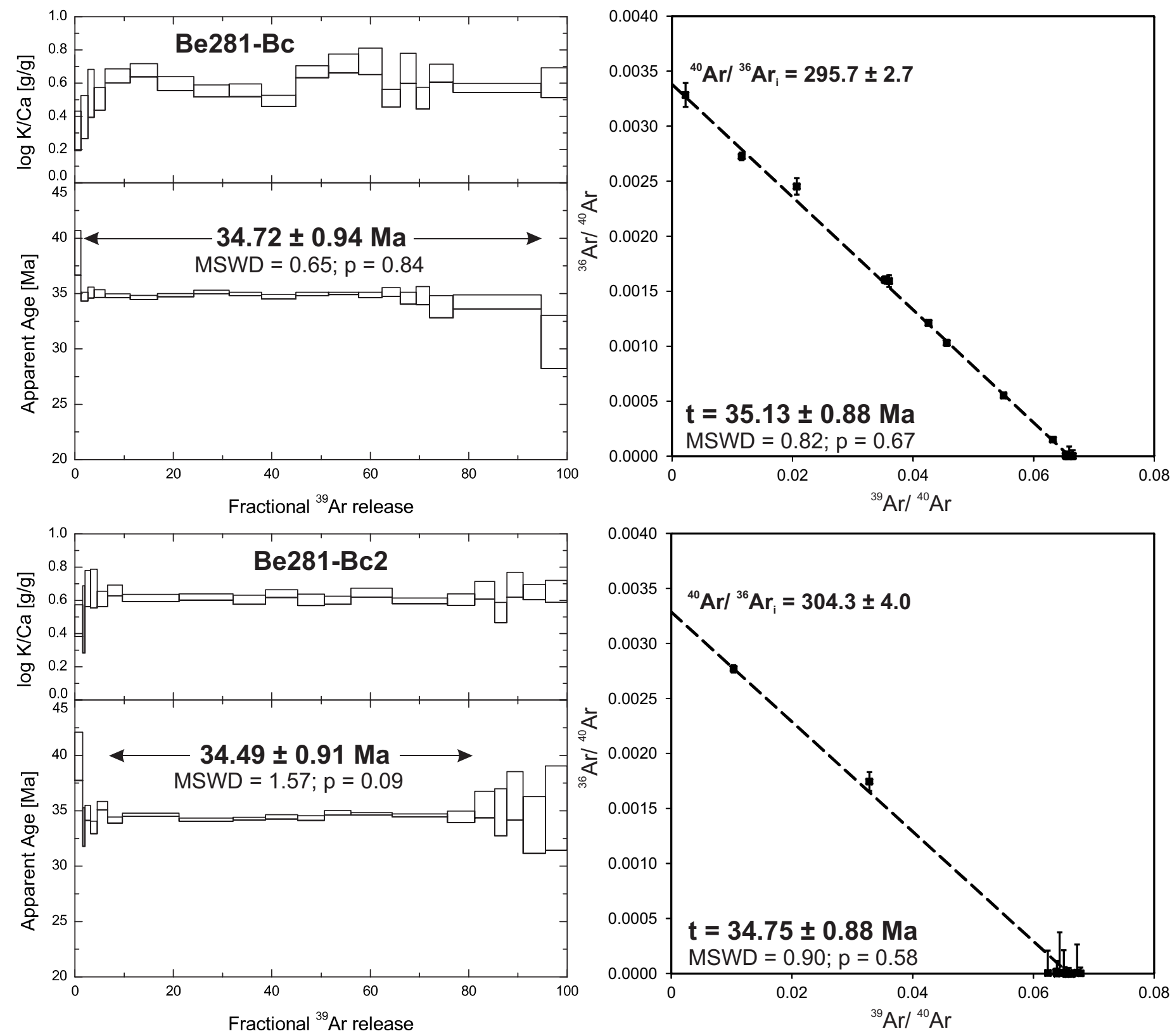

Figure A1-C 

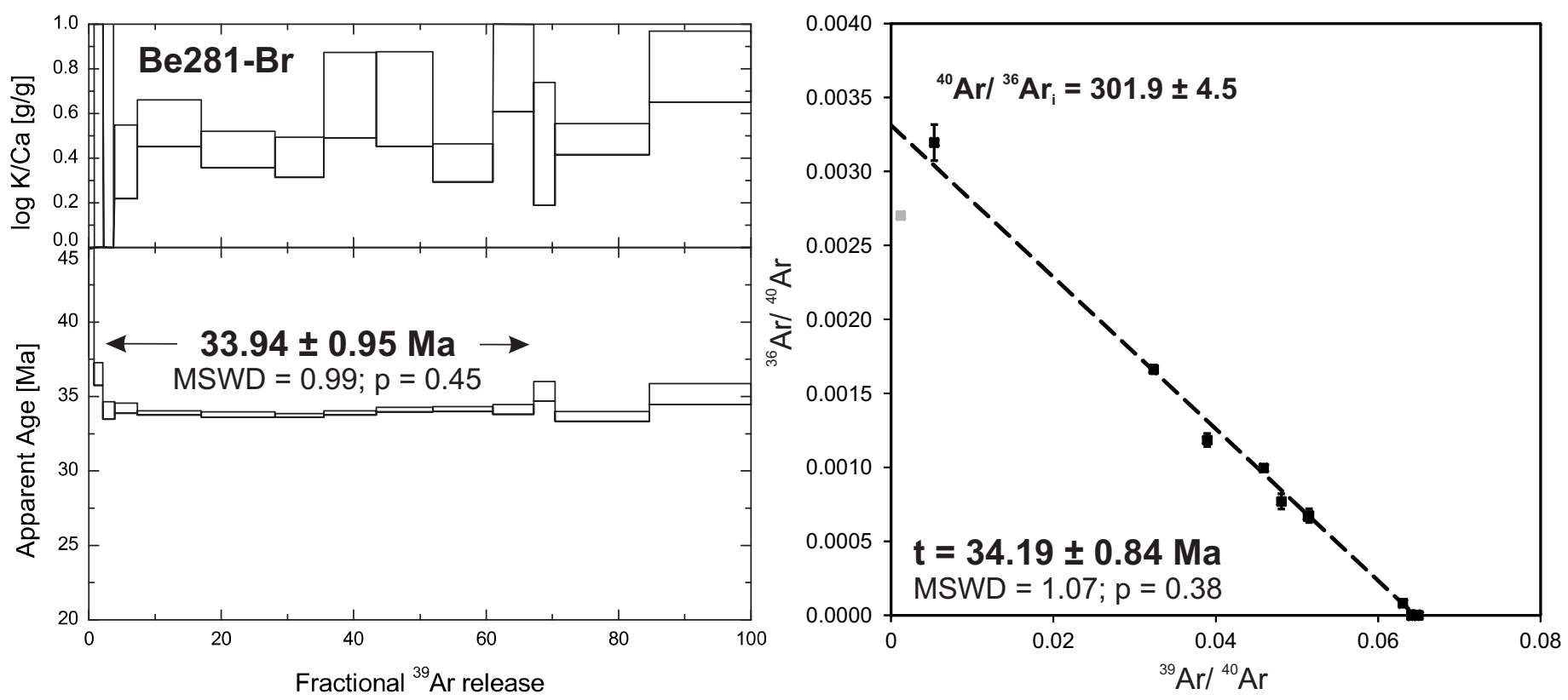

Figure A1-D 

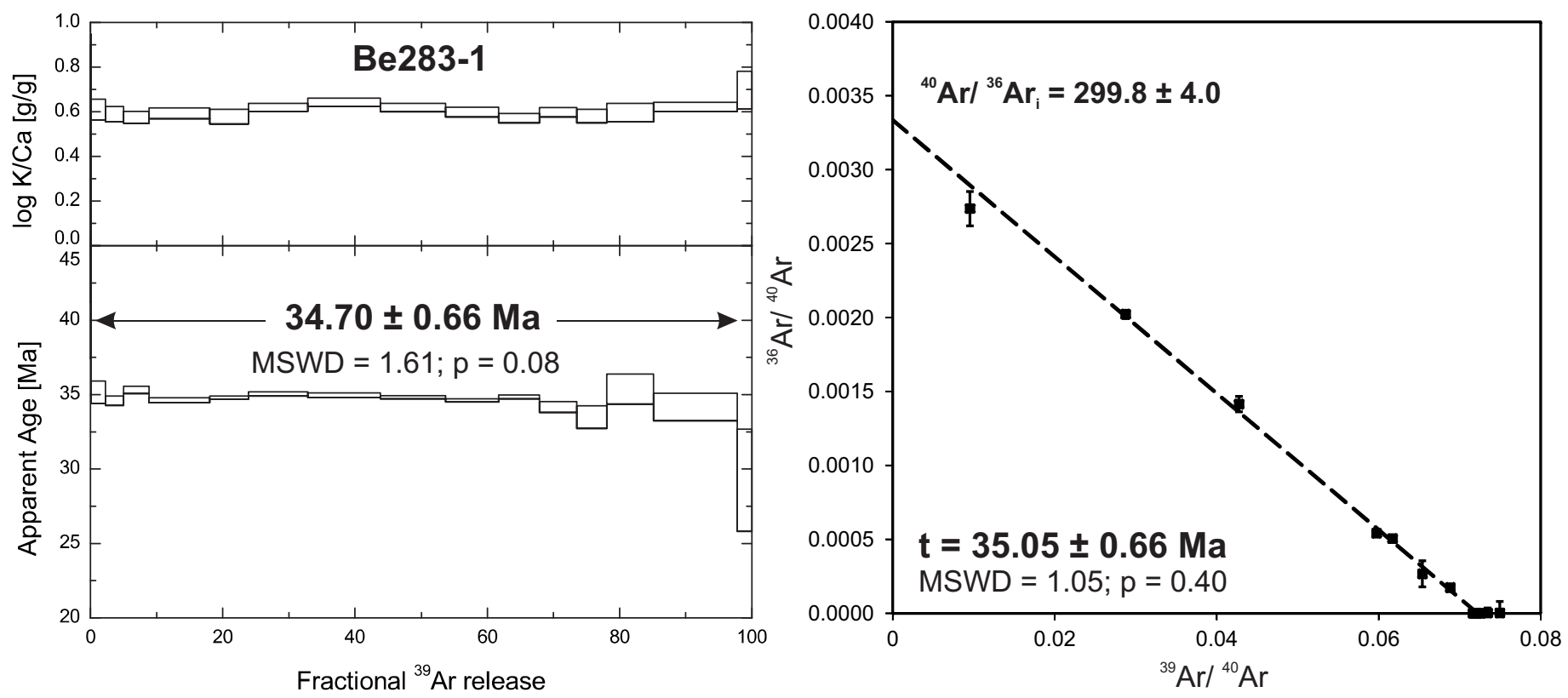

Figure A1-E 

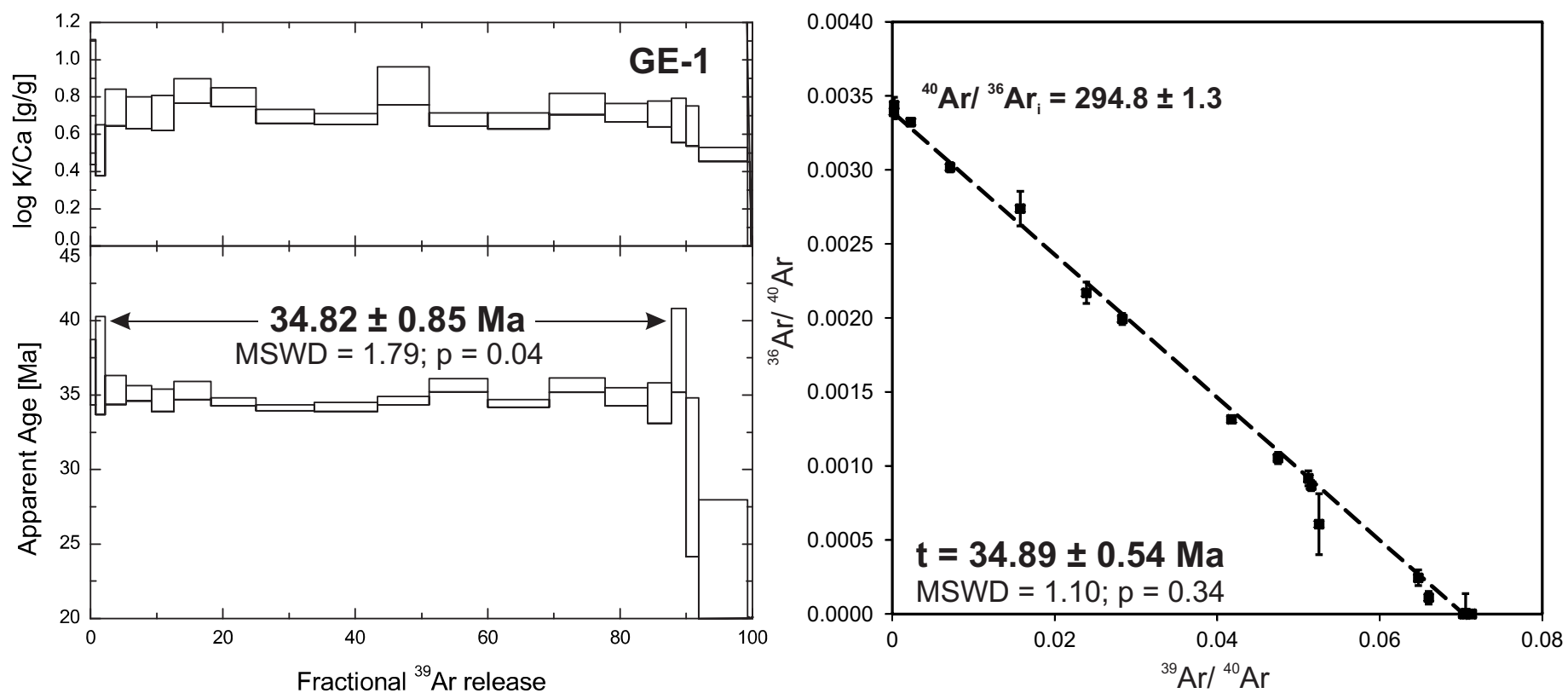

Figure A2 
Figure A3 Blank levels for all analysed tektites/impact melts, showing the correction curve for blank measurements (furnace and line). The first (first three rows) and the second (last row) irradiation series differ in blank height by a factor of 5-10.
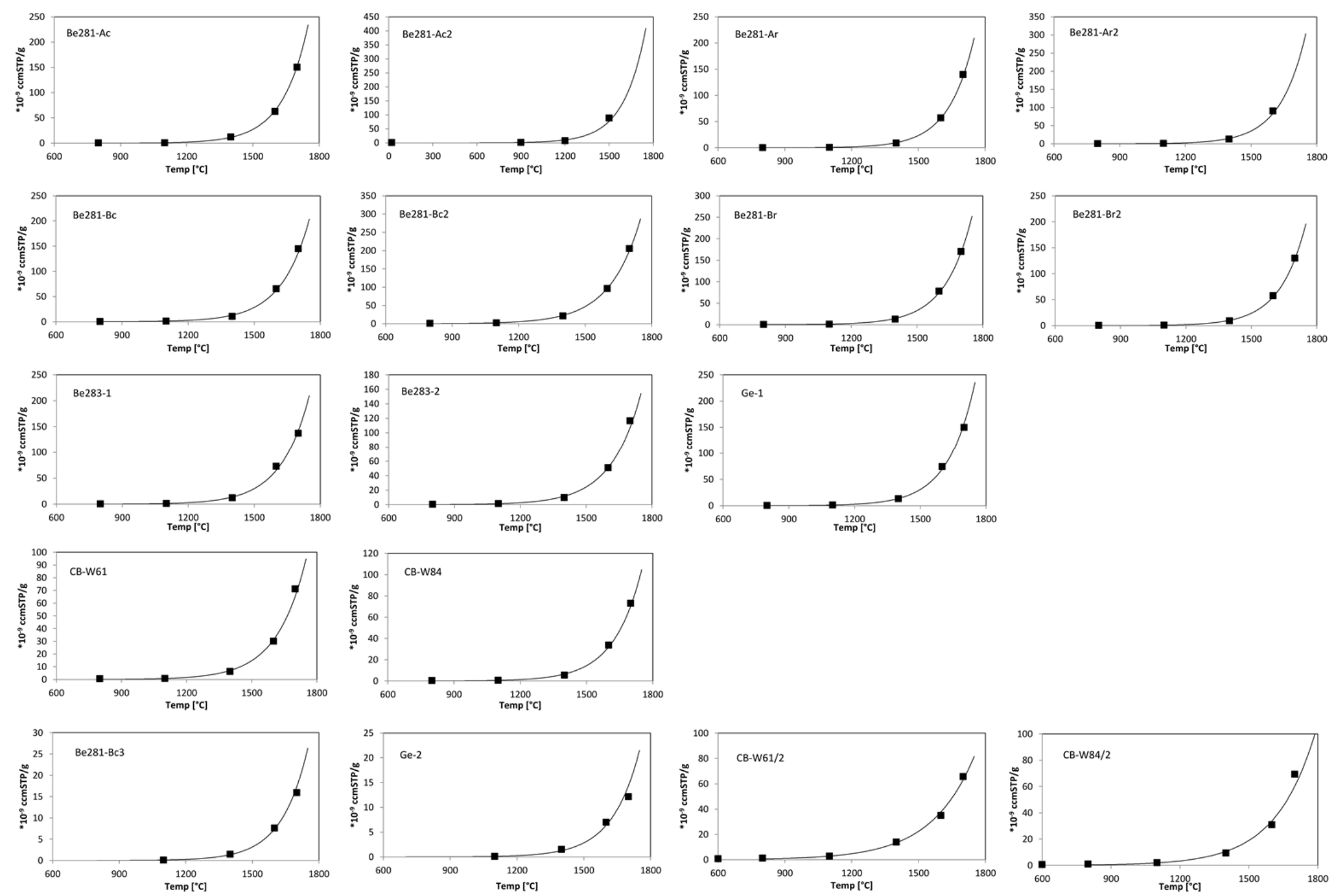